Florida International University FIU Digital Commons

\title{
Understanding the Role of the Bacteria, Isolated from the Hanford Site Soil, on the Fate and Transport of Uranium
}

Denny A. Carvajal

Florida International University, dcarv006@fiu.edu

DOI: $10.25148 /$ etd.FI1 1080810

Follow this and additional works at: https://digitalcommons.fiu.edu/etd

\section{Recommended Citation}

Carvajal, Denny A., "Understanding the Role of the Bacteria, Isolated from the Hanford Site Soil, on the Fate and Transport of Uranium" (2011). FIU Electronic Theses and Dissertations. 459.

https://digitalcommons.fiu.edu/etd/459 


\section{FLORIDA INTERNATIONAL UNIVERSITY}

Miami, Florida

UNDERSTANDING THE ROLE OF BACTERIA, ISOLATED FROM THE HANFORD SITE SOIL, ON THE FATE AND TRANSPORT OF URANIUM.

A thesis submitted in partial fulfillment of the

requirements for the degree of MASTERS OF SCIENCE

in

BIOMEDICAL ENGINEERING

by

Denny A. Carvajal

2011 


\section{To: Dean Amir Mirmiran}

College of Engineering and Computing

This thesis, written by Denny A. Carvajal, and entitled, Understanding the Role of the Bacteria, Isolated from the Hanford Site Soil, on the Fate and Transport of Uranium, having been approved in respect to style and intellectual content, is referred to you for judgment.

We have read this thesis and recommend that it be approved.

Chenzhong Li

Yelena Katsenovich, Co-Major Professor

Anthony J. McGoron, Co-Major Professor

Date of Defense: July 07, 2011

The thesis of Denny A. Carvajal is approved.

Dean Amir Mirmiran

College of Engineering and Computing

Dean Lakshmi N. Reddi

University Graduate School

Florida International University, 2011 


\section{DEDICATION}

This work is dedicated to science, and to the Department Of Energy - Florida International University Science and Technology Workforce Development Program along with its associated mentors and fellows. Without their support, and my passion for testing to increase our knowledge, the completion of this work would not have been possible. 


\section{ACKNOWLEDGMENTS}

I would like to thank Drs Anthony McGoron, Yelena Katsenovich, Chenzhong Li, Leonel Lagos, Dwayne McDaniel, Andrew A. Plymale, Allan Konopka, Jim Fredrickson, Alicia Fernandez-Fernandez, Surendra Dua and acknowledge help from Rakesh Guduru, Ravi Gudavalli, Sheydin Ng, Reshmi Banerjee and the DOE-FIU Fellows for their mentorship, advice and ability to facilitate this investigation. I would also like to thank the DOE-FIU Science and Technology Workforce Development Program for supporting me and this research.

Funding for this research was provided by US DOE Grant Number: DE-EM0000598. I would like to thank Dr. David Balkwill for providing Arthrobacter sp. strains and acknowledge Dr. Yanqing Liu from the FIU Mechanical Engineering Department for his assistance with the SEM/EDS of bacterial surface and composition analysis. 


\author{
ABSTRACT OF THE THESIS \\ UNDERSTANDING THE ROLE OF BACTERIA, ISOLATED FROM THE \\ HANFORD SITE SOIL, ON THE FATE AND TRANSPORT OF URANIUM by \\ by \\ Denny A. Carvajal
}

Florida International University, 2011

Miami, Florida

Professors Anthony J. McGoron and Yelena Katsenovich, Major Professors

Bacteria are known for their abilities to influence the geochemical processes and affect the mobility of contaminants in the subsurface. Arthrobacter strain G975 was studied to improve our understanding of their effect on uranium's fate and transport. The research experimentally identified and compared several parameters, including cell growth rate, cell viability, and the bacteria partition coefficient, $K_{d}$, under various uranium and bicarbonate concentrations mimicking Hanford Site subsurface environmental conditions, as well as the microbes ability to interact with uranyl phosphate minerals. The results show that the G975 strain can uptake up to $90 \%$ of the U(VI) concentrations tested, following linear isotherm models whose uptake capacity was measured up to $150.2 \pm$ $71.4 \mathrm{mg} / \mathrm{g}$ and decreased with increasing bicarbonate concentrations. AFM and $\mathrm{SEM} / \mathrm{EDS}$ analysis confirmed surface membrane uranium precipitates. The research presented here is part of a large effort to advance the understanding of the biogeochemistry processes and plausible remediation strategies concerning uranium contamination. 


\section{TABLE OF CONTENTS}

CHAPTER

PAGE

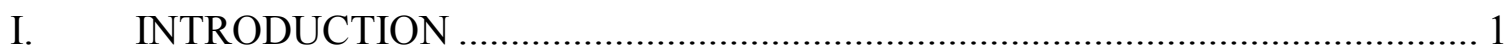

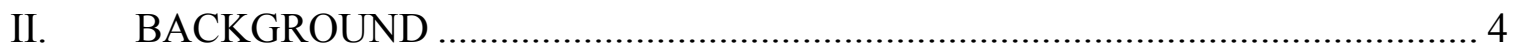

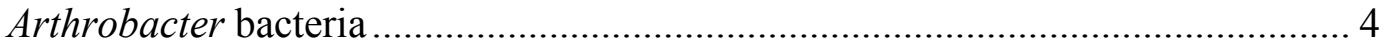

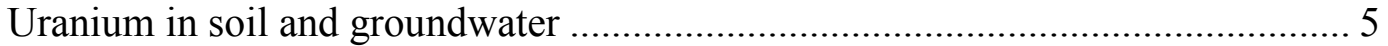

Effect of carbonate and dissolved organic carbon in U(VI) biosorption ................ 6

Effect of phosphate on uranium precipitation/dissolution ................................... 7

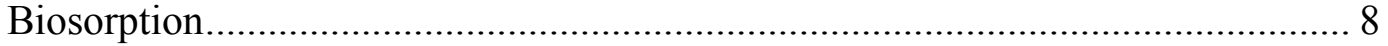

Microbial sorption and toxicity mechanism of actinides .................................. 9

Uranium sorption and toxicity mechanism .................................................. 10

III. STATEMENT OF PURPOSE .................................................................. 12

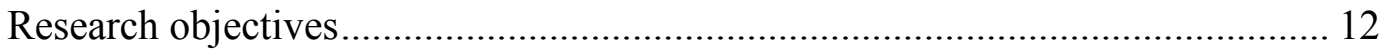

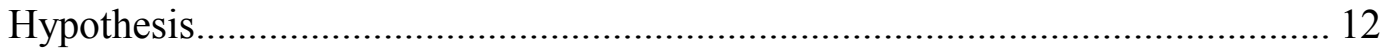

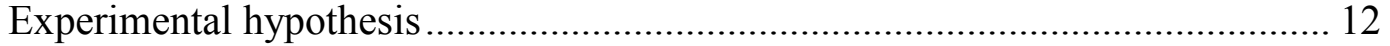

Research Questions .............................................................................. 13

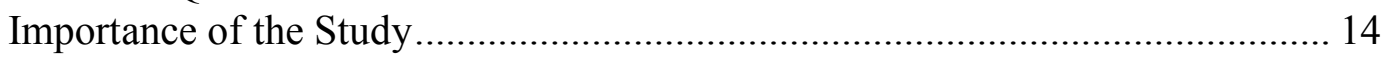

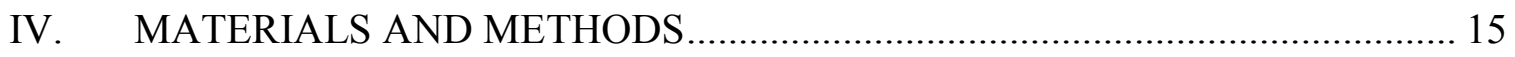

Arthrobacter Strains and Growth Culture Conditions ....................................... 15

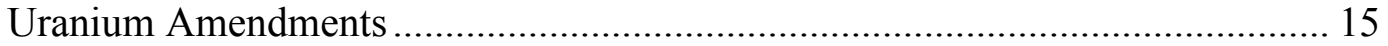

Cell viability \& cell count........................................................................... 16

Bacterial resistance to uranium ................................................................. 17

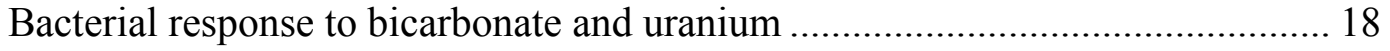

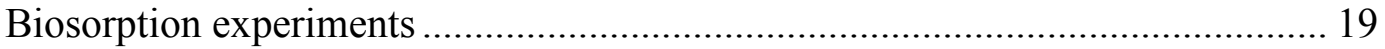

Synthetic groundwater and changes in bicarbonate concentrations ......... 19

Bacterial mass and cell count correlation .......................................... 20

Biosorption kinetics ..................................................................... 20

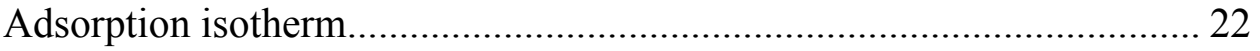

Uranium desorption .................................................................... 24

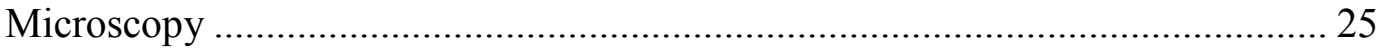

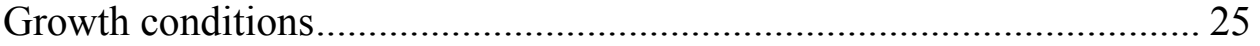

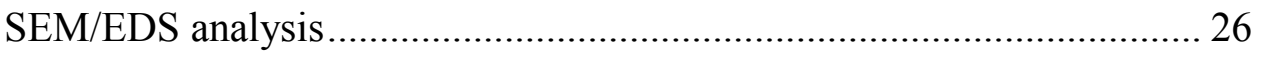

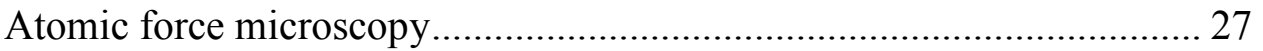

Roughness measurements ............................................................. 28

Force Spectroscopy ..................................................................... 28

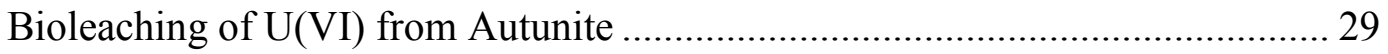

Bicarbonate media solution preparation ............................................ 30 
Non-contact autunite bioleaching ..................................................... 30

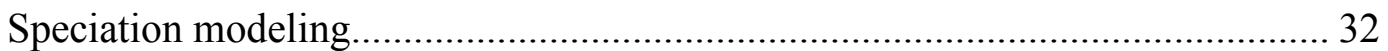

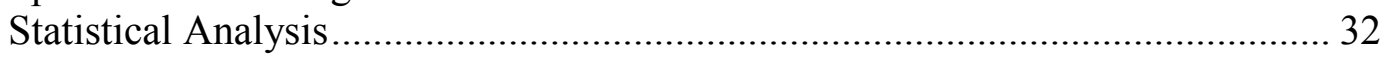

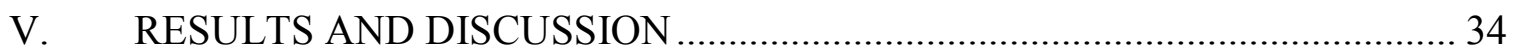

Assessment of Arthrobacter strains growth......................................................... 34

Assessment of Arthrobacter sp. G975 resistance to uranium (VI) ...................... 35

Correlation between bacterial mass and cell counts ........................................... 40

Visual MINTEQ speciation modeling .......................................................... 42

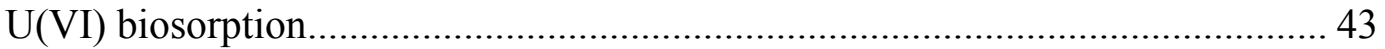

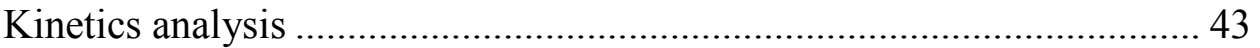

$2^{2}$ Factorial design uranium sorption at equilibrium........................... 49

Sorption isotherm ..................................................................... 52

Desorption experiments ............................................................ 58

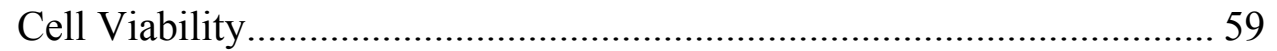

Effect of uranium on microbial surfaces using atomic force microscopy ............ 62

Uranium precipitation on the microbial cell surface............................. 63

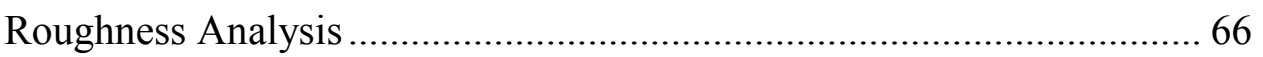

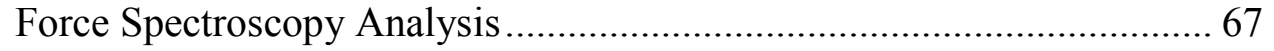

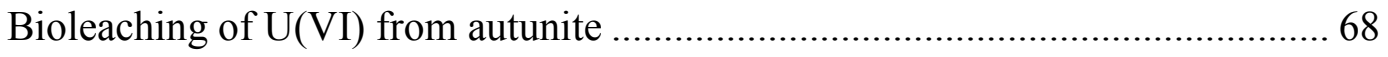

VI. CONCLUSIONS AND FUTURE WORK ...................................................... 72

VII. PUBLICATIONS \& POSTER PRESENTATIONS ........................................ 75

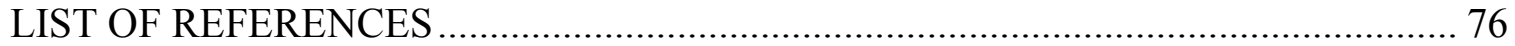




\section{LIST OF TABLES}

CHAPTER

PAGE

1. Stability Constants for Some Reactions Involving Uranyl-Carbonate Aqueous Species7

2. Pseudo 2nd-order model simulation sorption kinetic rates, $\mathrm{k}$ rate constant $(\mathrm{mgU}(\mathrm{VI}) / \mathrm{g} / \mathrm{min})$, and equilibrium adsorption capacity $(\mathrm{Qe}=\mathrm{mgU}(\mathrm{VI}) / \mathrm{g})$ for Arthrobacter Sp. G975 in carbonate amended $\mathrm{SGW}$ at $\mathrm{pH} 7.3,25^{\circ} \mathrm{C},(\mathrm{n}=3)$.

3. Two Way ANOVA: Effects of U(VI) and bicarbonate concentrations on the uranium uptake by Arthrobacter sp. G975 at equilibrium (24 hours), in $\mathrm{SGW} \mathrm{pH} \mathrm{7.3,} 25^{\circ} \mathrm{C} \ldots \ldots . .51$

4. Simulated results of biosorption isotherm with Langmuir, Freundlich, and linear equations Arthrobacter sp. G975 at various bicarbonate concentrations in SGW, pH 7.3, $250 \mathrm{C}, 24$ hours $(\mathrm{n}=3)$.

5. Average U(VI) bioaccumulation by Arthrobacter bacterial cells 65

6. The average roughness ( $\mathrm{Ra}$ ) and a standard deviation (SD) of three Arthrobacter strains grown at various concentrations of uranium. 66

7. Comparison of adhesion forces for G975 Arthrobacter Sp. 


\section{LIST OF FIGURES}

CHAPTER

PAGE

Figure 1. INCYTO C-Chip disposable hemocytometer and counting grid 17

Figure 2. Outline of $2^{2}$ factorial design to study biosorption kinetics. ........................... 22

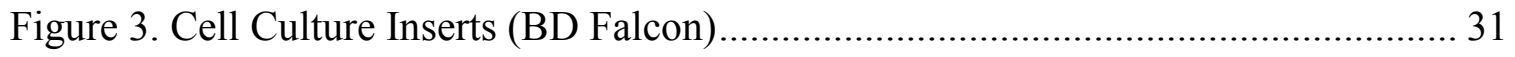

Figure 4. Growth for Athrobacter strain G975 over 7 days in HEPES buffered PYTG $5 \%$. A) Cell growth normalized to their initial cell number. B) Cell density, Log cell $/ \mathrm{ml}$,

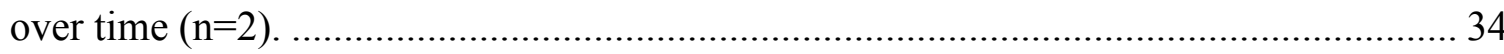

Figure 5. $\mathrm{pH}$ changes in bacterial broth solutions spiked with U(VI). G975 at 0, 100, \&120ppm of U(VI), 5\% PTYG media buffered with HEPES ...................................... 36

Figure 6. Changes in colony forming units of G975 over 7 days period in the presence of

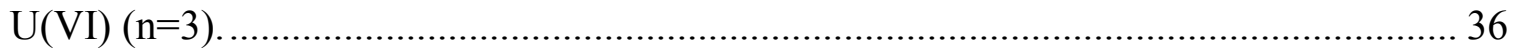

Figure 7. Changes in G975 density over 7 days period in the prescence of U(VI) $(n=3) .36$

Figure 8. Organic substrate TOC consumption in the presence of U(VI) for Arthrobacter G975 (n=1).

Figure 9. Time-depended changes in TOC consumption of Arthrobacter G975 cells grown in U(VI)-free and 20ppmU(VI) amended 5\%PTG media altered with $0 \mathrm{mM}, 5 \mathrm{mM}$,

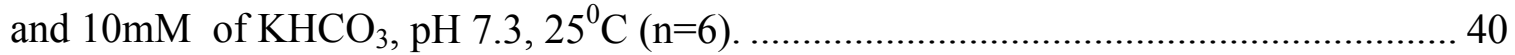

Figure 10. Correlation between weight vs. cell number for Arthrobacter G975 stain(n=2).

Figure 11. Morphology of G975. A) 100X magnification via light microscope. B) 20,000X magnification via SEM. C) $3.75 \mu \mathrm{m}^{2}$ area via AFM...................................... 42

Figure 12. MINTEQA2 speciation modeling of U(VI) species vs. added bicarbonate concentrations. A) Low [U(VI)], 75ppb. B) High [U(VI)], 20ppm.

Figure 13. Preliminary results on biosorption kinetics using G975 strain with 917.2 $\pm 120.6 \mathrm{ppb}$ of initial U(VI) in CF-SGW; $(\mathrm{n}=3)$ 
Figure 14. Percent of U(VI) uptake by Arthrobacter sp. G975 vs. Time, under low (0.3 ppm $\mathrm{U}(\mathrm{VI})$ and high $(14.7 \mathrm{ppm} \mathrm{U}(\mathrm{VI}))$ concentrations of $\mathrm{U}(\mathrm{VI})$ and 0 and $2.5 \mathrm{mM}$ of

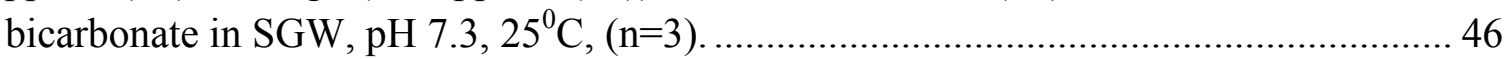

Figure 15. U(VI) uptake by Arthrobacter sp. G975 (mg/g) vs. Time, under low and high $\mathrm{U}(\mathrm{VI})$ concentrations and in bicarbonate amended $\mathrm{SGW}$ at $\mathrm{pH} 7.3,25^{\circ} \mathrm{C}$. Calculated values are based on the cells dry weight $(n=3)$.

Figure 16. Pseudo second -order rate equation regressions for Athrobacter sp. G975, under low and high $\mathrm{U}(\mathrm{VI})$ concentrations in bicarbonate amended $\mathrm{SGW}$ at $\mathrm{pH} 7.3,25^{\circ} \mathrm{C}$, $(\mathrm{n}=3)$. 48

Figure 17. Profile plots derived from the factorial design experiment; least square means of $\mathrm{U}(\mathrm{VI})$ uptake $(\mathrm{mg} / \mathrm{g})$, time, and $\mathrm{HCO}_{3}$ concentrations 50

Figure 18 Response surface model, Arthrobacter sp. G975 uranium uptake (mg/g) vs. $\mathrm{U}(\mathrm{VI})$ and bicarbonate concentrations at equilibrium (24 hours), in SGW, pH 7.3, 250C.

Figure 19. Calculated Langmuir U(VI) biosorption isotherms of Arthrobacter sp. G975 with bicarbonate concentrations varying in $\mathrm{SGW}$ from 0.0 to $5 \mathrm{mM}$ at $\mathrm{pH} 7.3,25^{\circ} \mathrm{C}, 24$ hours $(\mathrm{n}=3)$.

Figure 20. Calculated Freundlich U(VI) biosorption isotherms of Arthrobacter sp. G975 with bicarbonate concentrations varying in $\mathrm{SGW}$ from 0.0 to $5 \mathrm{mM}$ at pH 7.3, $25^{\circ} \mathrm{C}, 24$ hours $(\mathrm{n}=3)$.

Figure 21. Calculated Linear U(VI) biosorption isotherms of Arthrobacter sp. G975 with bicarbonate concentrations varying in $\mathrm{SGW}$ from 0.0 to $5 \mathrm{mM}$ at pH 7.3, $25^{\circ} \mathrm{C}, 24$ hours $(\mathrm{n}=3)$.

Figure 22. $\mathrm{K}_{\mathrm{d}}$ values from the linear isotherm of Arthrobacter sp. G975 with bicarbonate concentrations varying in $\mathrm{SGW}$ from 0.0 to $5 \mathrm{mM}, \mathrm{pH} 7.3,25^{\circ} \mathrm{C}, 24$ hours $(\mathrm{n}=3) \ldots \ldots \ldots . .56$

Figure 23. Percent of U(VI) uptake by Arthrobacter sp. G975 in SGW amended with bicarbonate concentrations varying from 0.0 to $5 \mathrm{mM}, \mathrm{pH} 7.3,25^{\circ} \mathrm{C}, 24$ hours $(\mathrm{n}=3) \ldots . .57$

Figure 24. Calculated percentages of U(VI) distribution in SGW solution, adsorbed on bacterial cell, and accumulated inside cells. A) $0 \mathrm{mM}$ of added bicarbonate. B) $2.5 \mathrm{mM}$ of added bicarbonate concentration (at $\mathrm{pH} 7.3,25^{\circ} \mathrm{C}, 24$ hours) ( $\left.\mathrm{n}=3\right)$. 
Figure 25. Colony Forming Units $(\mathrm{CFU} / \mathrm{mL})$ of all treatments after 24 hours of exposure

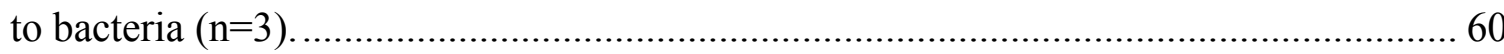

Figure 26. Spectrophotometer calibration curve for $A$. G975 in 5\% PYTG medium........ 61

Figure 27. Time-depended changes in Arthrobacter G975 cells density grown in U(VI)free and $20 \mathrm{ppmU}(\mathrm{VI})$ amended $5 \% \mathrm{PTG}$ media altered with $0 \mathrm{mM}, 5 \mathrm{mM}$, and $10 \mathrm{mM}$ of

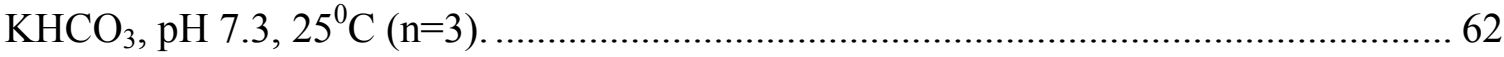

Figure 28. G975 control sample (scan size $2.94 \times 2.94 \mu \mathrm{m} 2$ ) showing its unusual wrinkled surface morphology. The topagraphy image on the left $(Z$ range $200 \mathrm{~nm})$ and frictional image $(0.3 \mathrm{~V})$ on the right.

Figure 29. G975 cultured in the media amended with 10ppm of U(VI), (scan size $1.45 \times$ $1.45 \mu \mathrm{m} 2$; phase angle $60^{\circ}$ ). Phase image clearly shows crystalline deposition on the cell surface.

Figure 30. 3D micrograph of cell surface topology of G975 cultured in the media amended with 10ppm of U(VI). Scan size $2 \mu \mathrm{m}$.

Figure 31. 3D micrograph of cell surface topologies of G975 cultured in the media amended with $10 \mathrm{ppm}$ of U(VI). Scan size $389 \mathrm{~nm}$

Figure 32. Top and bottom view of Cell Culture Insert with autunite mineral powder separated from bacteria.

Figure 33. Changes for aqueous $\mathrm{U}(\mathrm{VI})$ as a function of time for the non-contact natural autunite dissolution insert experiments inoculated with Arthrobacter G975 strain separated by a 0.4 um porous membrane $(n=2)$.

Figure 34. Measured U(VI) concentrations before and after inoculation with G975 in the insert non-contact natural autunite dissolution experiment $(\mathrm{n}=2)$. 70 


\section{INTRODUCTION}

From 1943 until 1989, the Hanford Site in Washington State, approximately 1,500 $\mathrm{km}^{2}$, produced plutonium for nuclear weapons. Materials research and fuel fabrication that occurred at the site's southern extremity, also known as the 300 Area, generated wastes that were sluiced into process ponds constructed and maintained to avoid contamination of the nearby Columbia River, less than 1,000 feet away. The ponds received constant and intermittent releases of waste varying in composition and volume, including caustic alkaline and acidic fluids, as well as slurries containing uranium, aluminum, and copper. The North and South 300 Area Process Ponds received long-term historic seepage/spills of acidic or neutral uranium wastes $(58,000 \mathrm{~kg}$ of disposed uranium over $32 \mathrm{yr}$ ) to the thin and shallow 300 Area vadose zone soil (Hanford formation sediment, primarily flood deposited sands and gravels) and groundwater. Despite extensive remediation efforts, persistent uranium groundwater plumes formed in multiple locations at Hanford. These sites contain uranium concentrations exceeding the U.S. Environmental protection Agency (EPA) $30 \mathrm{ppb}$ standard for drinking water supplies. Due to the water table fluctuations (i.e., multiple rise-and-fall cycles in the river), uranium levels in some areas varied greatly from $\sim 50 \mathrm{ug} / \mathrm{L}$ to $>300 \mathrm{ug} / \mathrm{L}$ (1).

Uranium (VI), or $\mathrm{U}(\mathrm{VI})$, is the most stable valence of uranium under oxidizing conditions that readily forms complexes with a variety of ligands (2). Common ligands in the environment that form stable uranyl complexes include: hydroxyl, phosphate, carbonate, silicate and organic substances (3)(4)(5). Thus, it's not surprising to see remedial actions implementing phosphate treatments in order to sequester uranium 
through the formation of stable and insoluble autunite minerals (6). However, aqueous orthophosphate may jump-start microbial activity because it's a readily available nutrient for various microorganisms that thrive under oligotrophic conditions (7), much like the nutrient poor Hanford soil. Arthrobacter sp., a common soil isolate in Hanford soil, are aerobic, high-G+C, chemoorganotrophic, gram-positive bacteria (8). The abundance of Arthrobacter sp. in the bacterial populations of the actinide-contaminated Hanford Site sediments makes them a representative species to study their impact on the fate and mobility of uranium in the soil and groundwater. Bacterial cell walls are rich in proteins and lipids that contain functional groups such as carboxyl and phosphate, which are able to bind with uranium. This research is focused on investigating the uranium biogeochemical processes that get catalyzed by Arthrobacter sp., and the effect of bicarbonate concentration on those processes (i.e., sorption, sorption kinetics, and bioavailability).

This study demonstrates the significance of bacteria-uranium interactions by focusing on Arthrobacter sp. This bacteria is one of the most common groups in soils and is found in fairly large numbers in Hanford soil as well as other subsurface environments contaminated with heavy metals and radioactive materials (9)(10)(11)(12). Balkwill et al. (10) reported the predominance of the genus Arthrobacter among the culturable aerobic heterotrophic bacteria from the Hanford Site sediments. In addition, Arthrobacter-like bacteria were the most prevalent in the highly radioactive sediment samples collected underneath the leaking high-level waste storage tanks and accounted for about of onethird of the total soil isolatable bacterial population (8). This research provides a more 
comprehensive understanding of Arthrobacter bacteria and their role in the fate and transport of uranium in the subsurface under the oxidized environmental conditions pertaining to the Hanford Site. 


\section{BACKGROUND}

\section{Arthrobacter bacteria}

Gram-positive Arthrobacter sp., which comprises a very diverse bacteria group known for their ability to survive in extreme conditions, are among the most numerous groups found in subsurface environments contaminated with heavy metals and radioactive materials; which includes the contaminated Hanford vadose zone soil (9)(10)(11). Previous studies have revealed that this genus is well adapted to nutrient-deprived (oligotrophic) conditions and, in addition, are highly desiccation-tolerant soil-inhabiting bacteria (9)(13)(14). Arthrobacter can survive in extreme conditions associated with UV-irradiation and radioactivity (14). Microorganisms with the closest match to a member of the genus Arthrobacter were the most prevalent in the highly radioactive sediment samples collected underneath the leaking radionuclide storage tanks at the Hanford Site and accounted for about one-third of the total soil isolatable bacterial population (8).

In this study, we attempted to demonstrate the significance of bacteria-uranium interactions by focusing on a bacterial strain of Arthrobacter sp. Balkwill et al. (10) reported the predominance of the genus Arthrobacter among the culturable aerobic heterotrophic bacteria from the Hanford Site sediments with this group accounting for roughly up to $25 \%$ of the subsurface isolates. In addition, Arthrobacter-like bacteria were the most prevalent in the highly radioactive sediment samples collected underneath the leaking high-level waste storage tanks and accounted for about of one-third of the total 
soil isolatable bacterial population (8). Their abundance and their relatively high resistance to the toxic form of U(VI) made microorganisms of the genus Arthrobacter species the focus of this investigation to provide a more comprehensive understanding of their biogeochemistry in oxidized conditions and to study fate and transport of uranium in subsurface environments pertaining to the Hanford Site.

\section{Uranium in soil and groundwater}

The element uranium (U) has a standard atomic weight of $238.03 \mathrm{~g} / \mathrm{mol}$ with an atomic number of 92. U exists as aqueous (mobile) and sorbed/precipitated (immobile) phases in sediments where their relative concentrations are governed by equilibrium and/or kinetic reactions involving sorption/desorption and precipitation/dissolution (15). The rapid reduction rate of oxidized $U(V I)$ in some bacteria and the low solubility of reduced $U(I V)$ makes this biogeochemistry process an attractive bioremediation option for removing $\mathrm{U}$ from contaminated groundwater which typically exists as uranyl carbonate (16). At most sites, where molecular oxygen is present, most $U$ in the aqueous phase will be in the form

of the hexavalent uranyl cation $\mathrm{UO}_{2}{ }^{2+}$. The uranium contamination in Washington state's Hanford Site is primarily found in oxic circumneutral-to-mildly-basic geochemical conditions, where $\mathrm{U}(\mathrm{VI})$ dominates as the highly soluble and stable uranyl ion, $\mathrm{UO}_{2}{ }^{2+}$ (17)(18). Being very soluble and possessing complicated chemical behavior in natural systems, uranium (VI) is a very difficult contaminant for mobility predictions. Aqueous uranium can easily adsorb onto soil minerals and bacterial surfaces such that its mobility and speciation in the environment are affected (19). 


\section{Effect of carbonate and dissolved organic carbon in U(VI) biosorption}

Uranium's behavior in natural systems depends on aqueous speciation and concentration of ligands (e.g. carbonate, calcium) forming uranyl complexes (17). Carbonate, phosphorus $(\mathrm{P})$, and $\mathrm{pH}$ are influential because in solutions above $\mathrm{pH} 5$, the uranyl ion hydrolyzes, forming aqueous hydroxide complexes and polymers of uranyl hydroxide (1). These complexation reactions often result in the formation of mobile aqueous species or precipitation of insoluble U-bearing minerals (20). According to Langmuir, the hydroxy complexes are relatively weak and, in most groundwater, uranyl occurs as stronger complexes with dissolved carbonate (1).

Aqueous carbonate at a common groundwater $\mathrm{CO}_{2}$ pressure of $10^{-2}$ to $10^{-3.5}$ atm are the predominant species affecting the dissolution of actinides and facilitating uranium desorption reactions from soil and sediments, thus increasing uranium mobility in natural waters (21). The mobility of $\mathrm{U}(\mathrm{VI})$ in aquifers with circumneutral $\mathrm{pH}$ conditions is explained by the formation of highly soluble and stable uranyl-carbonato complexes, $\mathrm{UO}_{2}\left(\mathrm{CO}_{3}\right)_{2}{ }^{2-}$ and $\mathrm{UO}_{2}\left(\mathrm{CO}_{3}\right)_{3}^{4-}$. In a calcium-rich environment, the large formation constants of soluble calcium uranyl carbonate complexes, $\left[\mathrm{Ca}_{2} \mathrm{UO}_{2}\left(\mathrm{CO}_{3}\right)_{3}{ }^{0}(\mathrm{aq})\right.$; $\left.\mathrm{CaUO}_{2}\left(\mathrm{CO}_{3}\right)_{3}{ }^{2-}\right]$, influences the speciation of uranium $(21)(22)$. The stability constants for these reactions are presented in Table 1. (23). 
Table 1. Stability Constants for Some Reactions Involving Uranyl-Carbonate Aqueous Species

\begin{tabular}{|c|l|}
\hline Reactions & $\mathrm{Log}_{10} \mathrm{~K}$ \\
\hline $\mathrm{UO}_{2}^{2+}+\mathrm{CO}_{3}^{2-}=\mathrm{UO}_{2} \mathrm{CO}_{3}^{0}$ & 9.94 \\
\hline $\mathrm{UO}_{2}^{2+}+2 \mathrm{CO}_{3}^{2-}=\mathrm{UO}_{2}\left(\mathrm{CO}_{3}\right)_{2}^{2-}$ & 16.61 \\
\hline$U O_{2}^{2+}+3 \mathrm{CO}_{3}^{2-}=\mathrm{UO}_{2}\left(\mathrm{CO}_{3}\right)_{3}^{4-}$ & 21.84 \\
\hline $2 \mathrm{Ca}^{2+}+\mathrm{UO}_{2}^{2+}+3 \mathrm{CO}_{3}^{2-}=\mathrm{Ca}_{2} \mathrm{UO}_{2}\left(\mathrm{CO}_{3}\right)_{3}$ & $29.80^{\mathrm{a}}$ \\
\hline $\mathrm{UO}_{2}^{2+}+\mathrm{Ca}^{2+}+3 \mathrm{CO}_{3}^{2-}=\mathrm{Ca}_{2} \mathrm{UO}_{2}\left(\mathrm{CO}_{3}\right)_{3}^{-2}$ & 25.4 \\
\hline${ }^{\mathrm{a}}(24)$. & \\
\hline
\end{tabular}

\section{Effect of phosphate on uranium precipitation/dissolution}

The presence of phosphate in soil and groundwater systems can control the actinide behavior in geological settings due to the formation of uranyl-phosphate complexes that feature extremely low solubilities under circumneutral $\mathrm{pH}$ conditions (25). Autunite and meta-autunite minerals $\left\{\mathrm{X}^{\mathrm{n}^{+}}{ }_{3-\mathrm{n}}\left[\left(\mathrm{UO}_{2}\right)\left(\mathrm{PO}_{4}\right)\right]_{2} \mathrm{xH}_{2} \mathrm{O}\right\}$ largely limit the mobility of dissolved U(VI) in soils contaminated by actinides such as at the Hanford Site and are an extremely important group of uranyl minerals when considering $U$ sequestration. Autunite minerals precipitation, as a result of polyphosphate injection, was identified as the most feasible remediation strategy for sequestering uranium in contaminated groundwater and soil in situ (26). The autunite mineral features a basal sheet-like structure due to the ability of uranyl ion to polymerize and bond with ligands along its equatorial plane (27). Autunite sheet structure, normally characterized by tetragonal 
morphology, is formed by the sharing of vertices between uranyl square bipyramids and phosphate tetrahedra, with a composition of $\left[\left(\mathrm{UO}_{2}\right)\left(\mathrm{PO}_{4}\right)\right]^{-}$. The solubility constant of the calcium form of autunite, $\log \mathrm{K}_{\mathrm{sp}}$, has been measured as -44.7 (2)(17). Associated solubility products are presented in eq. 1 .

$$
\mathrm{Ca}\left(\mathrm{UO}_{2}\right)_{2}\left(\mathrm{PO}_{4}\right)_{2} \cdot \mathrm{xH}_{2} \mathrm{O}_{(\mathrm{s})}=\mathrm{xH}_{2} \mathrm{O}_{(\mathrm{l})}+\mathrm{Ca}^{2+}+2 \mathrm{PO}_{4}^{3-}+2 \mathrm{UO}_{2}{ }^{2+}
$$

The release of $\mathrm{U}$ and $\mathrm{P}$ during dissolution, as previously investigated by Wellman et al. (28), was found to be non-stoichiometric over the $\mathrm{pH}$ 7-10 range conditions. The aqueous phosphate concentrations were basically unchanged during the equilibrations, indicating that the solid phase dissolution reactions did not significantly affect the phosphate concentrations (29).

\section{Biosorption}

A variety of mechanisms exist for the removal of heavy metal from solutions by biomaterials, ranging from purely physico-chemical interactions, such as adsorption to cell walls, to mechanisms dependent on metabolism, such as transport, internal compartmentation, and extracellular precipitation by excreted metabolites (30). Biosorption can be defined as the ability of biological materials (solid phase biosorbent, biomass) to bind and accumulate heavy metals (sorbate) from aqueous solutions (solvent) through metabolically mediated or physico-chemical pathways of uptake (31)(32). Due to the higher affinity of the sorbent for the sorbate species, the latter is attracted and bound there by different mechanisms. The biosorption process continues until equilibrium is reached between the solid-bound sorbate species and its remaining portion in solution due 
to the higher affinity of the biosorbent for the sorbate (31). A metal is only "removed" from solution when it is appropriately immobilized (33). Adsoption reactions can retard the migration of radionuclides, preventing them from escaping to the accessible environment, and dampen radionuclide peak releases that might otherwise exceed health standards (17). A plot that describes the amount of a species sorbed as a function of its concentration in solution, measured at constant temperature, is called a sorption isotherm. The distribution coefficient, $K_{d}$, for uranium can be extracted from these curves. The $K_{d}$ value depends on the oxidation state of the actinide, $\mathrm{pH}$, competitive adsorption, the nature and extent of actinide complexing, and the characteristics of sorbent phases (17). Biosorption is an economically attractive treatment alternative suited for metal removal and recovery (33).

\section{Microbial sorption and toxicity mechanism of actinides}

Microbial activities in many environmental systems are additional layers of complexity that affect U(VI) mobility. In nature, a variety of bacteria may enhance the mobility of heavy metals or radionuclides by dissolution and desorption due to the secretion of protons and various ligands. Physical and chemical interactions involving adsorption, ion exchange, and complexation are the driving forces for extracellular association of uranium with bacterial cell surfaces, which does not depend on metabolism. The bacterial cell wall contains proteins and lipids with functional groups such as the carboxyl and phosphate that help in the adsorption of the uranyl species at environmentally relevant $\mathrm{pH}$ values (34)(35)(36). The results of EXAFS analysis of the association of $U$ with bacterial cells showed that it was associated predominantly with phosphate in the form of uranyl phosphate, and with other ligands such as the carboxyl species (37)(35). In addition, 
Arthrobacter sp. can sequester uranium intracellularly in precipitates closely associated with polyphosphate granules. This phenomenon is associated with cell metabolism and possibly involves the transport of metals across the cell membrane, which can be mediated by the mechanism used to convey metabolically essential ions such as sodium and potassium (34). Previous research identified uranium precipitations on the bacteria surface as autunite/meta-autunite mineral phases at $\mathrm{pH}$ ranging from 4.5 to 7 (38)(39)(40). There has also been reports of precipitation found around the cells of Citrobacter sp. composed of $\mathrm{HUO}_{2} \mathrm{PO}_{4}$ and $\mathrm{NaUO}_{2} \mathrm{PO}_{4}$ at $\mathrm{pH} 6.9$ (41)(42).

\section{Uranium sorption and toxicity mechanism}

Bacterial resistance to heavy metals is ecologically important. Arthrobacter have developed very efficient molecular adaptation mechanisms that enhance the stability of nucleic acids, proteins, and lipids, allowing the bacteria to survive in stressful conditions (43). The tolerance to U exhibited by Arthrobacter strains can be explained by several cellular mechanisms, as previously reported by other researchers (39)(36)(44). One mechanism is bioadsorption, which was a focus of Tsuruta, who examined the adsorptive capabilities of Arthorbacter nicotianae, Bacillus, and Streptomyces spp. (45)(46)(47). Tsuruta demonstrated an extremely high microbial ability to adsorb uranyl ions, with removal of up to $95 \%$, and hypothesized that cell surface adsorption was the prevailing mechanism in removing uranyl ions from aqueous solution. Fowle et al. (48) studied U sorption onto B. subtilis and reported that $\mathrm{U}$ sorption onto that bacterium was governed by the formation of U-carboxyl and U- phosphoryl surface species. It was suggested that polyphosphates (PolyP) perform numerous biological functions, including phosphate 
storage in the cell, a chelator of metals $\left(\mathrm{Mn}^{2+}\right.$ and $\left.\mathrm{Ca}^{2+}\right)$, a $\mathrm{pH}$ buffer, physiological adjustments to growth, stress, and variety of nutritional limitations (34). In addition, PolyP plays an important role in intracellular uranium accumulation as a detoxification mechanism in limiting $\mathrm{U}$ toxicity (38). 


\section{STATEMENT OF PURPOSE}

\section{Research objectives}

The objective of this study is to determine if Hanford Site Arthrobacter isolate G975 influences uranium mobility in the subsurface via biogeochemical processes such as biosorption and bioleaching, and to better understand their affect on uranium's transport. The research will experimentally study and compare several parameters, including cell growth rate, cell viability, and the bacteria partition coefficient, $\mathrm{K}_{\mathrm{d}}$, under various uranium and bicarbonate concentrations mimicking Hanford Site subsurface environmental conditions. Field Emission Scanning Electron Microscope (FE-SEM), Atomic Force Microscopy (AFM), and Energy Dispersive X-Ray Spectroscopy (EDS) microscopy analysis will help to visualize and characterize processes that may occur at the cell surface.

\section{Hypothesis}

It is hypothesized that: Abundant native Hanford Site soil bacteria isolates like the Arthrobacter sp. influence the uranium transport in soil and groundwater.

\section{Experimental hypothesis}

It is hypothesized that:

1. Hanford Site Arthrobacter bacteria isolate G975 remain viable when exposed to uranium concentrations currently found in the 300 Area groundwater ( $300 \mathrm{ppb} \mathrm{U}$ (VI)). 
2. The adsorption coefficient, $\mathrm{Kd}$, of the Arthrobacter G975 bacteria isolate is greater than that of the Hanford Site soil for uranium $(\mathrm{Kd}=0.86-1.85 \mathrm{~mL} / \mathrm{g})$.

3. $\mathrm{U}(\mathrm{VI})$ complexation with bicarbonate ion reduces its adsorption reactions rates, adsorption capacity and uranium toxicity to bacteria.

4. Uranium uptake by bacteria occurs by both internal accumulation and extracellular adsorption onto bacterial cell surfaces.

5. Bacterial secretion of metabolites will decrease the stability of uranyl phosphate by causing uranium to leach out from autunite minerals.

\section{Research Questions}

1. Is the Arthrobacter bacteria isolate from Washington state's Hanford Site soil capable of withstanding the toxic effects of uranium?

2. Do bacteria influence the processes that govern the fate and transport of uranium in the Hanford Site soils and sediments?

3. How do bicarbonate concentrations affect bacterial growth and uranium uptake in uranium containing matrix?

4. How does the uptake and binding of $\mathrm{U}(\mathrm{VI})$ change the chemical surface composition of Hanford Site bacteria compared to its U(VI) free counterpart?

5. Are the Arthrobacter bacteria isolates from Washington state's Hanford Site able to influence the mobility of radionuclides by dissolution of autunite mineral created in soil as a result of remedial actions? 


\section{Importance of the Study}

The adsorption phenomenon is a very important physico-chemical process in the distribution of soluble uranium at solid-water interfaces (e.g., soils, rocks and sediments) that affects uranium transport in the subsurface (49). This study helped to identify the $\mathrm{U}(\mathrm{VI})$ - bacteria partition coefficient, $\mathrm{K}_{\mathrm{d}}$, a measure of how tightly uranium binds to the bacteria, and evaluated the microbial effect on the mobility of uranium in the subsurface. This knowledge advances our understanding of the role of bacteria in phosphate remediation technology. In addition, this research investigated bacteria- U(VI) interactions under oxidizing $\mathrm{pH}$-neutral conditions, and evaluated microbial growth and tolerance in the presence of the uranyl cation $\left(\mathrm{UO}_{2}^{2+}\right)$, which is a predominant contaminant at the Hanford Site. The research presented here is part of a larger effort to advance the understanding of the biogeochemistry processes and plausible remediation strategies concerning uranium contamination. 


\section{MATERIALS AND METHODS}

\section{Arthrobacter Strains and Growth Culture Conditions}

The Arthrobacter strain, previously isolated from the Hanford subsurface as a part of the geomicrobiological investigation conducted for the DOE Deep-Subsurface Science Program, was obtained from the Subsurface Microbial Culture Collection (SMCC) (Florida State University, Tallahassee). Detailed descriptions of site geology, sample collections procedures, and methods of bacteria isolation are available from Van Waasbergen et al. (11). The strain identification, previously confirmed by $16 \mathrm{~S}$ rDNA phylogeny, was Arthrobacter oxydans G975 (10)(11). The strains were cultured in a PYTG medium consisting of $5 \mathrm{~g} / \mathrm{L}$ peptone, $5 \mathrm{~g} / \mathrm{L}$ tryptone, $10 \mathrm{~g} / \mathrm{L}$ yeast extract, $10 \mathrm{~g} / \mathrm{L}$ glucose, $0.6 \mathrm{~g} / \mathrm{L} \mathrm{MgSO}_{4} \cdot 7 \mathrm{H}_{2} \mathrm{O}, 0.07 \mathrm{~g} / \mathrm{L} \mathrm{CaCl}_{2} \cdot 2 \mathrm{H}_{2} \mathrm{O}$ and $15 \mathrm{~g} / \mathrm{L}$ agar. The media was prepared in deionized water (DIW) (Barnstead NANOpure Diamond Life Science (UV/UF), Thermo Scientific), autoclaved at $121^{\circ} \mathrm{C}$ and 15 psi for 15 minutes, then

allowed to cool to about $50^{\circ} \mathrm{C}$ before being poured into sterile petri dishes. The Arthrobacter strains were aerobically grown to reach confluence in $150 \mathrm{ml}$ sterile Erlenmeyer tubes amended with $50 \mathrm{ml}$ of PYTG media at $29^{\circ} \mathrm{C}$ in the shaker/incubator.

\section{Uranium Amendments}

The uranyl nitrate stock solution was prepared from uranyl nitrate hexahydrate in DIW water and subsequently diluted to $\mathrm{U}(\mathrm{VI})$ concentrations varying from 1 to $80 \mathrm{ppm}$. The $\mathrm{U}(\mathrm{VI})$ in the stock solution was analyzed using a Kinetic Phosphorescence Analyzer KPA-11 (Chemcheck Instruments, Richland, WA) in the amount close to the theoretical value of $47.4 \%$. 


\section{Cell viability \& cell count}

To account for viable bacteria, a well-mixed homogeneous aliquot $(0.01 \mathrm{~mL}-0.1 \mathrm{~mL})$ of the suspension from each test vial was uniformly spread on the sterile petri dishes containing a 5\% PTYG growth media mixed with $15 \mathrm{~g} / \mathrm{L}$ of agar in serial dilutions, and then the grown colonies on the plate were counted. Viable microorganisms were calculated from the number of colony-forming units (CFU) found on a specific dilution. A serial dilution helped to obtain a colonies number on each plate ranging between 30 and 300. The colony-forming units were then calculated as eq. (2).

$$
\frac{C F U}{m l}=\frac{C F U * \text { Dilution Factor }}{\text { Sample volume }(\mathrm{ml})}
$$

Inoculated plates were kept inverted in an incubator at $29^{\circ} \mathrm{C}$. In addition, the agar plating was used to provide a quick visual check for contamination and to maintain colonies from each stage of the enrichment for the duration of the experiment.

The morphological details, such as cell size and the presence of a rod-coccus growth cycle, were continually monitored using an optical microscope. The morphological features recorded for colonies included the presence of pigmentation, shape, type of edge, type of surface, and elevation. The cell density (cells $/ \mathrm{mL}$ ) was calculated with the help of a glass hemocytometer (Fisher Scientific, Pittsburg, PA). Cell counts in the samples containing uranium employed INCYTO C-Chip disposable hemocytometers. The hemocytometer is a microscope slide with a rectangular indentation, creating a chamber that is engraved with a grid of perpendicular lines (Figure 1). 


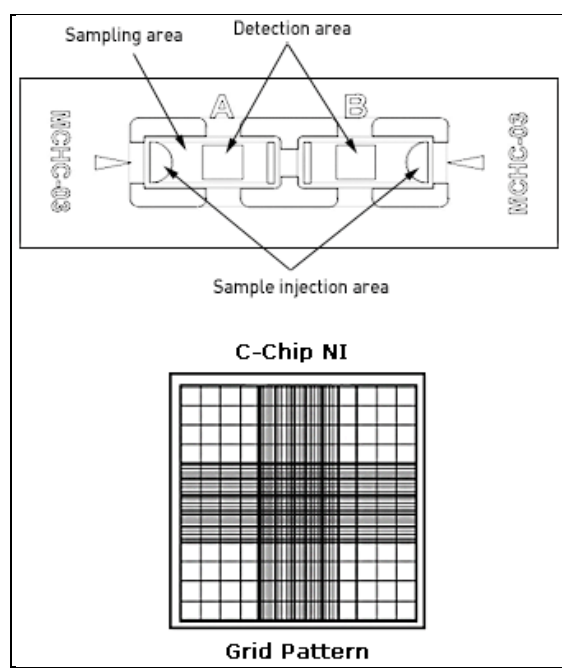

Figure 1. INCYTO C-Chip disposable hemocytometer and counting grid

Having known the area bounded by the lines as well as the depth of the chamber, the cell density in a specific volume of fluid and in a bacterial broth solution was calculated from a sample, homogenously distributed inside the chamber. Once the average cells count was obtained, it was multiplied by the dilution factor and the volume factor, $10^{4}$, in order to obtain the final concentration of cells per mL. In addition, cell density was determined by measuring the absorbance at $660 \mathrm{~nm}$ by means of spectrophotometer (UV-1601, Shimadzu) and relating them to known cell numbers counted via the use of the hemocytometer.

\section{Bacterial resistance to uranium}

Sterile polypropylene tubes containing $3 \mathrm{~mL}$ of $5 \%$ PTYG media were prepared for each bacterial strain G975. Tubes were covered with a foam stopper to provide aerobic conditions and kept in the incubator set to $29^{\circ} \mathrm{C}$. All of the sets were inoculated with approximately $1.2 \mathrm{E}+06$ cells of the G975 strain to bring the final concentration of 4.E +05 cells $/ \mathrm{mL}$. Prior to inoculation, cell stock suspensions were vortexed for 10 
seconds and counted using an INCYTO C-Chip disposable hemocytometer to calculate the amount of cell suspension needed to obtain the desired cell concentration in the tubes. Each tube was independently sampled in a sacrificial manner at different time intervals to eliminate any effects from sampling on bacteria cultures to obtain cell counts in the hemocytometer. After the tubes' inoculation, uranium was injected as uranyl nitrate from a U(VI) stock solution of $0.005 \mathrm{M}$ to achieve the desired concentrations ranging between 0.5 ppm-57 ppm. Samples from each group were assayed at days $0,1,3,5$, and 7 by obtaining a representative sample. At each time interval, subsamples were aseptically removed to estimate cell numbers by means of hemocytometer, and to conduct a cell viability assessment by plating on the sterile petri dishes. Inoculated plates were kept inverted in an incubator at $29^{\circ} \mathrm{C}$. Viable microorganisms were calculated from the number of colony forming units (CFU) found on a specific dilution. In addition, the agar plating was used to provide a quick visual check for contamination and to maintain colonies from each stage of the enrichment for the duration of the experiment.

\section{Bacterial response to bicarbonate and uranium}

The hypothesis that the presence of aqueous bicarbonate may affect the toxicity of U(VI) on cells was tested by measuring the total organic carbon (TOC) and monitoring bacterial cells growth via spectrophotometer in a separate time-based experiment conducted in triplicate. Initially, cells in a concentration of $\log 8$ cells $/ \mathrm{mL}$ were exposed to $20 \mathrm{ppm}$ of $\mathrm{U}(\mathrm{VI})$ in bicarbonate-bearing solutions composed of $0 \mathrm{mM}, 5 \mathrm{mM}$ and $10 \mathrm{mM}$ of $\mathrm{HCO}_{3}$. The controls were prepared U(VI)-free and amended with the same concentration of bicarbonate. Cells were harvested $24 \mathrm{~h}$ after exposure, washed with DIW to remove the remaining bicarbonate and $\mathrm{U}(\mathrm{VI})$ and then re-suspended in fresh 5\% PTYG media to a 
concentration of $\log 6.8$ cells $/ \mathrm{mL}$ to monitor changes in cell densities and to a concentration of $\log 7.7$ cells $/ \mathrm{mL}$ to determine the consumption of TOC.

The TOC of centrifuged cell-free solutions was analyzed using a Shimadzu TOC analyzer with an autosampler (TOC-V CSH). Each analysis was repeated until the standard deviation was less than $3 \%$. The bacterial cell densities in suspension at different time intervals were measured by optical density (OD) at $660 \mathrm{~nm}$ wavelength by a spectrophotometer (UV-1601, Shimadzu) at the same time for all treatments over a two day period.

\section{Biosorption experiments}

\section{Synthetic groundwater and changes in bicarbonate concentrations}

The sorption experiments were conducted with carbonate-free (CF-SGW) and carbonate amended synthetic groundwater (SGW) under conditions relevant to the 300 Area Hanford Site subsurface. The CF-SGW formulation that mimics the natural groundwater composition at an excavation site above the former South Process Pond in the 300 Area was made from available salts. The formulation was based on the April 19, 2003 analysis (50). The CF-SGW consists of $88.21 \mathrm{mg} / \mathrm{L}$ of $\mathrm{CaCl}_{2} .2 \mathrm{H}_{2} \mathrm{O}, 19.99 \mathrm{mg} / \mathrm{L}$ of $\mathrm{MgCl}_{2}, 5.22$ $\mathrm{mg} / \mathrm{L}$ of $\mathrm{KCl}, 520.58 \mathrm{mg} / \mathrm{L}(2 \mathrm{mM})$ of HEPES, dissolved in DIW. The SGW amended with various bicarbonate concentrations was created using $\mathrm{KHCO}_{3}$ with $\mathrm{pH}$ adjusted to 7.3 by $0.5 \mathrm{M} \mathrm{HCL}$ or $0.5 \mathrm{M} \mathrm{NaOH}$, as required. SGW solutions with ambient levels of bicarbonate concentrations and those amended with $0,0.5,2.5$, and $5 \mathrm{mM}$ of $\mathrm{KHCO}_{3}$ were tested in the sorption experiments. 


\section{Bacterial mass and cell count correlation}

The direct cell count by a hemocytometer was applied to find a correlation between bacterial mass based on the dry weight and cell count for future uranium biosorption studies. Bacteria were cultured in aerobic conditions at $29^{\circ} \mathrm{C}$ until high turbidity and confluency was reached. The procedures to find a bacterial mass followed the modified EPA 340.2 method using an analytical balance, capable of weighing to $0.01 \mathrm{mg}$, and Nylon membrane filters (Whatman) with $0.45 \mu \mathrm{m}$ pore size. Homogeneous bacteria samples of increasing volume (i.e $0.5,1,2,4$, and $6 \mathrm{~mL}$ ) were pipetted onto the filter for vacuum filtration, placed in an oven at $70^{\circ} \mathrm{C}$ for $24 \mathrm{hrs}$, and then cooled for another 24 hrs in a desiccator to remove moisture and stabilize sample weight. Obtained bacterial mass values were plotted against the estimated cell number count corresponding to the particular volume of sample used.

\section{Biosorption kinetics}

A preliminary experiment was conducted to determine the appropriate sampling rate for future experiments. A CF-SGW solution amended with $917.2 \pm 120.6 \mathrm{ppb}$ of U(VI) and inoculated with 4E+10 cells of G975 strain bacteria was randomly sampled for 5.25 hours. Based on the preliminary results discussed in the Results \& Discussion section, the experiment was modified with the changes outlined below.

The U(VI) biouptake rate was studied by conducting a $2^{2}$ factorial design approach using uranium and bicarbonate concentrations at two different levels or concentrations as the two independent variables, and the bacterial uranium uptake as the dependent variable. SGW solutions at equilibrium with atmospheric $\mathrm{CO}_{2}$ were referred to as the lowbicarbonate media and SGW modified with $2.5 \mathrm{mM} \mathrm{KHCO}_{3}$ was referred to as the high- 
bicarbonate concentration. The low and high concentrations of U(VI) in SGW media, 0.3 $\mathrm{ppm} / 0.005 \mu \mathrm{M}$ and $14.7 \mathrm{ppm} / 0.247 \mu \mathrm{M}$ respectively, was made by the addition of the appropriate volumes from an $100 \mathrm{ppm}$ uranyl nitrate $\left[\mathrm{UO}_{2}\left(\mathrm{NO}_{3}\right)_{2} \cdot 6 \mathrm{H}_{2} \mathrm{O}\right]$ stock solution prepared in DIW. The chosen experimental design scheme allowed us to investigate the influence of bicarbonate on the uranium biosorption kinetics and statistically model the relationships between two major variables, $\mathrm{U}(\mathrm{VI})$ and bicarbonate at equilibrium. The design provided four possible treatments (Figure 2) sampled at different time intervals. The time-based experiment was conducted in triplicate and all treatments were sampled and measured at the same time $(0.25,0.75,2,4,6,24$, and 48 hours $)$ to avoid statistical blocks with their respective controls. Experiments were conducted in triplicate using $4 \mathrm{ml}$ of SGW inoculated with $4 \mathrm{E}+10$ cells of G975 strain in $15 \mathrm{ml}$ polypropylene sterile tubes. The tubes were kept in the incubator shaker at $60 \mathrm{rpm}$ and $25^{\circ} \mathrm{C}$ for 24 hours. Tubes were centrifuged for $5 \mathrm{~min}$ at $3000 \mathrm{rpm}$ and cell-free supernatants from all treatments were sampled and processed for U(VI) by means of KPA. In addition, bacterial samples after 24 hours of U(VI) exposure were tested for cell viability, by plating subsequently diluted homogeneous aliquots on the sterile agar-containing petri dishes. The metal uptake $\mathrm{q}(\mathrm{mg}$ ion metal / $\mathrm{g}$ bacteria) was determined by solving the mass balance equation presented in eq. 3 .

$$
q=\frac{\left(C_{0}-C_{t}\right) * V}{m}
$$

Where $\mathrm{C}_{0}$ and $\mathrm{C}_{\mathrm{t}}$ are the initial and final metal ion concentrations (mg/L), respectively, $\mathrm{V}$ is the volume of solution $(\mathrm{mL})$, and $\mathrm{m}$ is the bacteria dry weight $(\mathrm{g})$. 


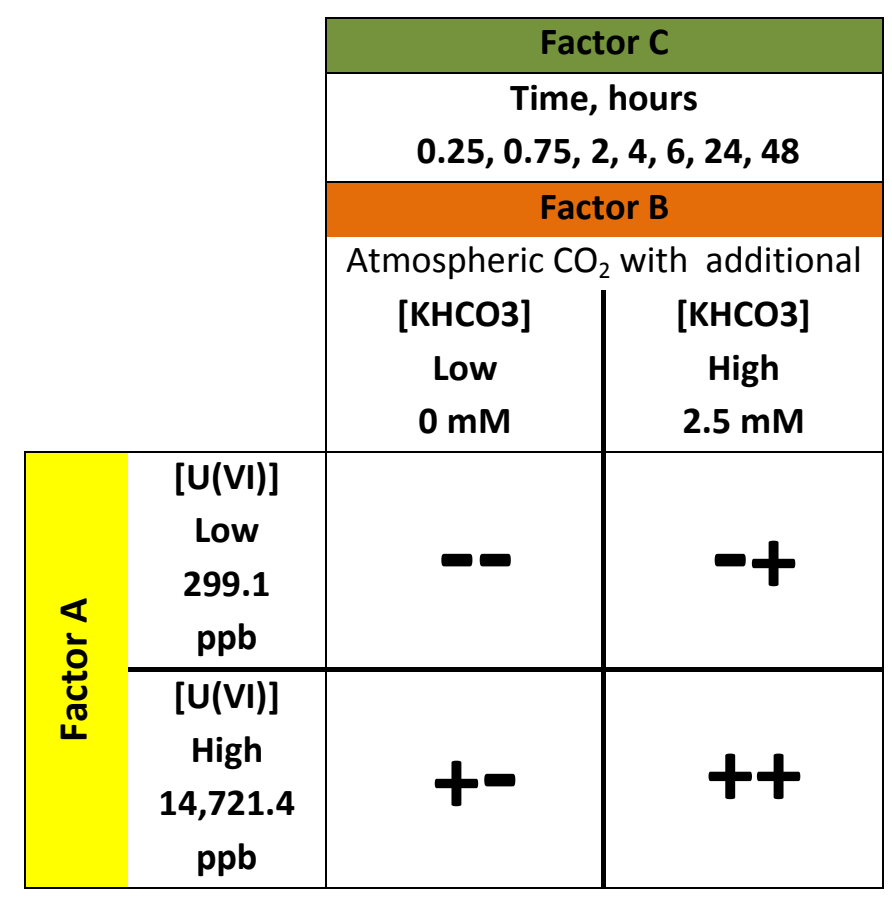

Figure 2. Outline of $2^{2}$ factorial design to study biosorption kinetics.

\section{Adsorption isotherm}

The equilibrium U(VI) adsorption was carried out at different initial concentrations of $\mathrm{U}(\mathrm{VI})$ ranging from 0.5 to $20 \mathrm{ppm}$ while maintaining the dry weight of Arthrobacter sp. G975 at $0.24 \pm 0.05 \mathrm{mg}$ in each treatment. The dry weight of bacteria was indirectly estimated by relating the direct cell count obtained by a hemocytometer and the bacterial mass acquired by following the modified EPA method 340.2 for the same number of cells. The role of bicarbonate ions and their impact on U(VI) adsorption by bacteria was investigated using bicarbonate-bearing SGW at concentrations up to $5 \mathrm{mM}$.

The bacteria-inoculated uranium solutions were prepared in triplicate, having equal volumes of $4 \mathrm{ml}$ in $15 \mathrm{ml}$ polypropylene sterile tubes that were kept in the incubator shaker at $60 \mathrm{rpm}$ and $25^{\circ} \mathrm{C}$, allowing 24 hours for equilibration time. This time was 
determined from the results of the preliminary adsorption kinetics experiments previously described. In addition, the abiotic control tubes were prepared to quantify U(VI) losses due to adsorption on tube walls and caps. The $\mathrm{pH}$ for each solution remained unchanged for 24 hours, adjusted to 7.3 using $0.5 \mathrm{M}$ of $\mathrm{NaOH}$ or HCL. Tubes were centrifuged for 5 min at $3000 \mathrm{rpm}$ and then supernatant samples were assayed with the KPA instrument. The uranium uptake by the bacteria was calculated with eq. (3). Sorption isotherms were created by plotting the amount of metal uptake (q) against the equilibrium concentration of metal ions detected in the solution. The slope of this correlation is known as the partition coefficient, $\mathrm{K}_{\mathrm{d}}$, that corresponds to the distribution of metal ions between the aqueous and solid phases.

The linear, Freundlich, and the Langmuir sorption isotherms were used to simulate the adsorption capacity of uranium by Arthrobacter sp. G975 at equilibrium (51)(52)(53)(54). The Linear isotherm is presented in eq. (4) by the measured uranium concentration at equilibrium $\mathrm{Ce}$, and the partition coefficient, $\mathrm{K}_{\mathrm{d}}$, eq. (5).

$$
\begin{gathered}
q=K_{d} C_{e} \\
K_{d}=\frac{q}{C e}=\frac{m_{m o l ~ g}{ }^{-1}}{m o l m L^{-1}}=\left(\frac{m L}{g}\right)
\end{gathered}
$$


The Freundlich isotherm is an empirical generalization of the linear isotherm, with $\mathrm{K}_{\mathrm{f}}$ and 1/n as empirical constants (eq. 6).

$$
q=K_{f} C_{e}^{1 / n} \text { or } \log (q)=\log \left(K_{f}\right)+\frac{1}{n} \log \left(C_{e}\right)
$$

The Langmuir isotherm equation, eq. (7), describes the adsorption of gases onto clean solids and implies uniform adsorption on the saturated monolayer surface (Stumm et al. 1996).

$$
\frac{1}{\mathrm{q}}=\frac{1}{\mathrm{~S}_{\max }}+\frac{1}{\mathrm{C}_{\mathrm{e}} \mathrm{K}_{\mathrm{L}} \mathrm{S}_{\max }}
$$

A basic assumption of the Langmuir theory is that adsorption occurs at specific homogenous sites of the sorbent, and once a metal ion resides on a site, no further adsorption can take place (Ho et al. 2008). The characteristic constants of the Langmuir equation are $\mathrm{S}_{\max }$, the maximum adsorption for a complete monolayer $(\mathrm{mg} / \mathrm{g})$, and $\mathrm{K}_{\mathrm{L}}$, the adsorption equilibrium constant $(\mathrm{mg} / \mathrm{mL})$.

After the 24-hour exposure time to U(VI) in the biosoption experiment, each biotic treatment was tested for cell viability.

\section{Uranium desorption}

After biosorption experiments, the U(VI)- loaded G975 cells were harvested from the solutions to measure the amount of $\mathrm{U}(\mathrm{VI})$ adsorbed onto the bacterial surface versus U(VI) accumulated inside the cell. Cells were rinsed in DIW and re-suspended in $10 \mathrm{ml}$ of a strong uranium chelating agent, $10 \mathrm{mM}$ Ethylenediaminetetra-acetic acid disodium salt $\left(\mathrm{Na}_{2} \mathrm{EDTA}\right.$ ) with the $\mathrm{pH}$ adjusted to 7.2 (Acharya 2009). ASTM-A-380 defines chelating as "chemicals that form soluble, complex molecules with certain metal ions, inactivating the ions so that they cannot normally react with other elements or ions to 
produce precipitates." After 10 min of gentle agitation, the samples were centrifuged and the U(VI) concentrations in the supernatant were determined with the KPA instrument. This process allowed the $\mathrm{U}(\mathrm{VI})$ bound to the cell membrane to desorb back into solution. The mass of desorbed $\mathrm{U}(\mathrm{VI})$ was counted using eq. 8.

$$
\mathrm{U}(\mathrm{VI}) \text { adsorbed in } \mu \mathrm{g}=\mathrm{C}_{\text {desorbed }} \frac{\mu \mathrm{g}}{\mathrm{L}} * \text { EDTA volume (L) }
$$

The mass of uranium in solution at equilibrium and the total uranium mass was calculated in the same fashion, using initial $\left(\mathrm{C}_{0}\right)$ and equilibrium $\left(\mathrm{C}_{\mathrm{e}}\right) \mathrm{U}(\mathrm{VI})$ concentrations along with the $4 \mathrm{ml}$ of starting solution volume. Thus, the mass of internal accumulated U(VI) was estimated by solving the mass balance equation (eq. 9).

$$
[U]_{\text {Internal Accumulation }}=[U]_{\text {total }}-[U]_{\text {in solution }}-[U]_{\text {adsorbed }}
$$

\section{Microscopy}

To identify surface bound uranium adsorbed at the cell membrane and describe possible mechanisms for uranium uptake, several microscopy techniques where utilized, including: FE-SEM, to observe changes in the cell-surface morphology [JOEL, JSM6330F SEM]; AFM, to observe the morphological and physiological changes of live bacterial cell surface at a nanoscale spatial resolution [Veeco Instruments (Santa Barbara, California)]; and EDS, to determine the composition analysis of the microbial surface [Noran System Six Model 200]. The Meiji ML 2000 microscope was used for nondestructive examination of bacterial samples and quantification of cells by means of a hemocytometer.

\section{Growth conditions}

The Arthrobacter strains were aerobically grown to reach confluence in $15 \mathrm{ml}$ polypropylene sterile foam-stoppered centrifuge tubes amended with $3 \mathrm{~mL}$ of $5 \%$ PYTG 
media at $29^{\circ} \mathrm{C}$. Experimental tubes were inoculated with approximately 3.E+08 cells of the corresponding strain to bring the concentration of bacterial cells close to 1.E+08 (Log 8) cells/mL. Prior to inoculation, cells stock suspension was counted using an INCYTO C-Chip disposable hemocytometer to determine the amount of cells in the media needed to obtain the desired concentration in the tubes. Uranium was injected as a uranyl nitrate from a stock solution of $0.005 \mathrm{M}$ of $\mathrm{U}(\mathrm{VI})$ to achieve the required concentration ranging between $0.5 \mathrm{ppm}-27 \mathrm{ppm}$. Each set was prepared in triplicate and tubes were independently sampled at $24 \mathrm{hrs}$ to (i) obtain cell counts, (ii) prepare samples for the microscopy assays via atomic force microscope (AFM) and energy dispersive X-ray spectroscopy (EDS), and (iii) determine aqueous uranium concentrations. Aliquots of solution were collected for analysis of dissolved U(VI) followed by centrifugation of the tubes for $10 \mathrm{~min}$ at $2000 \mathrm{rpm}$. Analyses were conducted by means of a KPA using a dilution factor of 1:200. Bioaccumulation of uranium was calculated against bacteria-free controls. They were prepared with the same media solution amended with corresponding uranium concentrations and sampled at the same time intervals as experimental vials.

\section{SEM/EDS analysis}

The confirmation of precipitated uranium on the bacterial surface was obtained via SEM/EDS analysis. Sample preparation procedures for SEM/EDS analysis included the following steps. Cells were harvested by centrifugation at $4000 \mathrm{rpm}$ for $5 \mathrm{~min}$ from PTYG media amended with a specific concentration of U(VI) and washed twice with 50 $\mathrm{mM}$ of 2-(2-hydroxyethyl)-1-piperazine ethanesulfonic acid sodium salt hydrate (HEPES) prepared in DIW. The $\mathrm{pH}$ was adjusted to 7.2 with concentrated Fisher Scientific nitric acid $\left(\mathrm{HNO}_{3}\right)$. The cells were fixed in the $5 \mathrm{ml}$ of $2 \%$ glutaraldehyde in 
0.1M HEPES buffer at $\mathrm{pH} 7.2$ for $2 \mathrm{~h}$ at $4^{\circ} \mathrm{C}$. The fixative was changed at least two times. The material was removed by centrifugation and washed with $50 \mathrm{mM}$ HEPES buffer three times for $10 \mathrm{~min}$. The rinsed cells were then dehydrated in ethanol/ water solutions of $35 \%(\mathrm{v} / \mathrm{v}), 70 \%(\mathrm{v} / \mathrm{v})$, and $90 \%(\mathrm{v} / \mathrm{v})$ each for $10 \mathrm{~min}$, and two times in $100 \%(\mathrm{v} / \mathrm{v})$ for $10 \mathrm{~min}$. Dehydrated samples were immersed for $10 \mathrm{~min}$ each in $50 \%$ and $100 \%$ pure hexamethyldisilazane (HMDS) (Pierce Biothechnology, Inc, obtained from Fisher Scientific) followed by $10 \mathrm{~min}$ of air-drying to allow liquid to evaporate from the sample (55)(56). The dehydrated specimens were then kept in the desiccators until the time of SEM/EDS assay. Treated and control samples were mounted on aluminum stubs with double-sided sticky carbon tape and then coated for 30 seconds with a thin layer of gold to increase conductivity. The microstructure of the gold-coated samples (Pelco SC-7, Auto sputter coater) was characterized using a JOEL, JSM-6330F SEM at a voltage of 15 $\mathrm{kV}$. The cell surface composition was analyzed using a SEM-Energy-DispersiveSpectrometry (SEM-EDS) Noran System Six Model 200 at magnification of 2000.

\section{Atomic force microscopy}

A Multimode Nanoscope IIIa system from Veeco Instruments (Santa Barbara, California) was used for all AFM imaging analysis. Phase imaging was performed by using $\mathrm{Si}_{3} \mathrm{~N}_{4}$ soft tapping tips (BudgetSensors, Bulgaria) in order to ensure minimal sample damage with a force constant $7.4 \mathrm{~N} / \mathrm{m}$ and resonating frequency of $150 \mathrm{kHz}$. Phase imaging is an extension of TappingMode ${ }^{\mathrm{TM}} \mathrm{AFM}$ that provides detailed information about the surface structure and its properties beyond the simple topography, which is not possible with any other scanning probe microscopy (SPM) techniques. The phase image was obtained by mapping the phase of cantilever oscillation in tapping mode scans to detect variations in 
composition, friction and adhesion. Frictional imaging was performed by using the contact mode tip with a force constant $0.2 \mathrm{~N} / \mathrm{m}$ and resonating frequency of $15 \mathrm{kHz}$. In addition, AFM was used to acquire information on the surface topography of cells exposed to $\mathrm{U}(\mathrm{VI})$ at the three-dimensional (3D) level. 3D phase images were obtained in the tapping mode. Imaging was performed in laboratory conditions at $25^{\circ} \mathrm{C}$ and $55 \%$ relative humidity. Further, roughness analysis was conducted for quantifying the change in roughness of bacterial surfaces under different uranium concentrations. To ensure cell viability, the complete AFM analysis was performed within two hours after the sample was prepared.

\section{Roughness measurements}

A roughness value for bacterial cell surfaces was calculated from high resolution AFM topography images. The roughness value was calculated according to the relative heights of individual pixels in the image (57) over a selected area. The average roughness ( $\mathrm{Ra}$ ) was calculated from the average of the absolute values of profile height deviations from the mean level, as shown below.

$$
\mathrm{R}_{\mathrm{a}}=\frac{1}{\mathrm{n}} \sum_{j=1}^{n}\left|Z_{j}\right|
$$

Here, $Z$ is the maximum vertical distance between highest and lowest data points and $n$ is the number of scan points.

\section{Force Spectroscopy}

Force spectroscopy (FS) is a powerful tool for studying surface topography and nanometer-scale resolution changes in the surface physiochemical and mechanical properties, including bacterial cells. The dynamic changes occurring on the bacterial cell 
membrane before and after exposure to the various concentrations of uranium were evaluated using force spectroscopy analysis. The interaction force between the tip and the sample surface was recorded during intermittent approach and retraction of the tip (tapping) from the bacterial surface by monitoring the laser reflection from the deflecting cantilever using a position sensitive diode (PSD). This experimental approach allows for the monitoring of forces on the piconewton scale.

These interaction forces detect physiochemical changes over the desired region when scanned with similar tips (size and material), since the force is unique for the tip and underlying chemical domains on the cell membrane. The force was calculated by using a force distance (FD) curve (58)(59)(60) obtained by plotting the deflection of cantilever against the $\mathrm{Z}$ position of piezo. These FD curves were processed using SPIP software by ImageMetrology, Denmark (version 4.8), to determine adhesion forces. The average adhesion force reported in this study was obtained from 20 different FD curves generated randomly from an area on the sample surface of approximately $2 \mu \mathrm{m} \times 2 \mu \mathrm{m}$.

\section{Bioleaching of U(VI) from Autunite}

To address the role of microbes enhancing the mobility of radionuclides by dissolution of autunite minerals created in the soil as part of a remedial action, a study was conducted to determine if bacteria-mineral contact is necessary for uranium to leach from autunite mineral. Soluble uranium concentrations from a known amount of autunite mineral inside a sterile 6-well plate cultureware were monitored over time with and without the presence of bacteria. The bacteria was separated from the autunite mineral with a 0.4 um pore size membrane cell culture insert. 


\section{Bicarbonate media solution preparation}

Autunite leaching solutions were made from 5\% minimal PTG media consisting of $5 \mathrm{~g} / \mathrm{L}$ peptone, $5 \mathrm{~g} / \mathrm{L}$ tryptone, $10 \mathrm{~g} / \mathrm{L}$ glucose, $0.6 \mathrm{~g} / \mathrm{L} \mathrm{MgSO}_{4} .7 \mathrm{H}_{2} \mathrm{O}$, and $0.07 \mathrm{~g} / \mathrm{L} \mathrm{CaCl}_{2} .2 \mathrm{H}_{2} \mathrm{O}$. Yeast extract, due to the high phosphorus content, was not included in the media. Media was prepared in deionized water (DIW) (Barnstead NANOpure Diamond Life Science (UV/UF), Thermo Scientific), autoclaved at $121^{\circ} \mathrm{C}, 15 \mathrm{psi}$ for 15 minutes, and allowed to cool to about $30^{\circ} \mathrm{C}$. The media solution was then equally distributed between five $250 \mathrm{ml}$ bottles and separately amended to contain $0,1 \mathrm{mM}, 3 \mathrm{mM}, 5 \mathrm{mM}$ and $10 \mathrm{mM}$ of $\mathrm{KHCO}_{3}$. Media $\mathrm{pH}$ in each bottle was adjusted to $\mathrm{pH} 7.5$ with $0.1 \mathrm{~mol} / \mathrm{L} \mathrm{HCl}$ or $\mathrm{NaOH}$ and buffered with $20 \mathrm{mM}$ 2-(2-hydroxyethyl)-1-piperazine ethanesulfonic acid sodium salt hydrate (HEPES-Na). Each bicarbonate media solution was filter-sterilized $(0.2 \mu \mathrm{m})$ and kept refrigerated until the time of the experiment.

\section{Non-contact autunite bioleaching}

Natural Ca meta-autunite, $\mathrm{Ca}\left[\left(\mathrm{UO}_{2}\right)\left(\mathrm{PO}_{4}\right)\right]_{2} \cdot 3 \mathrm{H}_{2} \mathrm{O}$, obtained from Pacific North National Laboratory (PNNL), was characterized prior to experiments using ICP-OES, ICP-MS analyses, X-ray diffraction and SEM/EDS to confirm the mineral composition, structure, and morphology as $98-99 \%$ pure autunite. The autunite sample was powdered to have a size fraction of 75 to $150 \mu \mathrm{m}$ or -100 to +200 mesh with a surface area of $0.88 \mathrm{~m}^{2} / \mathrm{g}(28)$. The surface area of the samples used in the dissolution experiments was determined by Kr-adsorption BET analysis (28). Sterile 6-well cell culture plates with inserts (Figure 3) were used in the non-contact bioleaching experiments where natural $\mathrm{Ca}$ meta-autunite and bacteria cells were kept separately. The maximum recommended volume for the cultureware was used to increase the sampling number. A $3.2 \mathrm{ml}$ aliquot of sterile 
$\mathrm{KHCO}_{3}$ amended media prepared as previously described was dispensed in the appropriate well and $2.5 \mathrm{ml}$ inside the insert receptacle. The total volume inside each well added up to $5.7 \mathrm{ml}$. The cultureware inserts have $0.4 \mu \mathrm{m}$ cylindrical pores that transverse the membrane and only allow the diffusion of soluble uranium. Ten $\mathrm{mg}(10 \mathrm{mg})$ of sterilized autunite powder was added to the bottom of the well to reach a U(VI) concentration of $4.4 \mathrm{mmol} / \mathrm{L}$ with the insert in place. G975 cells in the amount of $\log 10^{6}$ cells $/ \mathrm{ml}$ were injected into the reactors at day 14 when autunite dissolved was close to a steady state. Abiotic controls were prepared to compare results with bacteria- bearing wells. Uranium leaching from autunite was determined by taking a $10 \mu \mathrm{L}$ sample from the inserts, at regular daily intervals, and processed on the KPA instrument after following the wet/dry ashing analytical procedures. The samples were analyzed with a 175 dilution factor. Prior to KPA analysis, sample aliquots were ashed on a hot plate in the presence of concentrated plasma grade nitric acid and hydrogen peroxide solutions. Wet digestion in $20 \mathrm{ml}$ scintillation glass vials was continued until a dry white precipitate was obtained, then vials were dry ashed in a furnace at $450^{\circ} \mathrm{C}$ for $15 \mathrm{~min}$. Samples were allowed to cool at room temperature followed by the dissolution of the precipitate by the addition of $1 \mathrm{M}$ nitric acid $\left(\mathrm{HNO}_{3}\right)$. Uranium calibration standards (SPEX certiPrep), blanks and check standards (95-105\% recovery) were analyzed for quality control. At the end of the leaching experiments, suspension $\mathrm{pH}$ was measured.

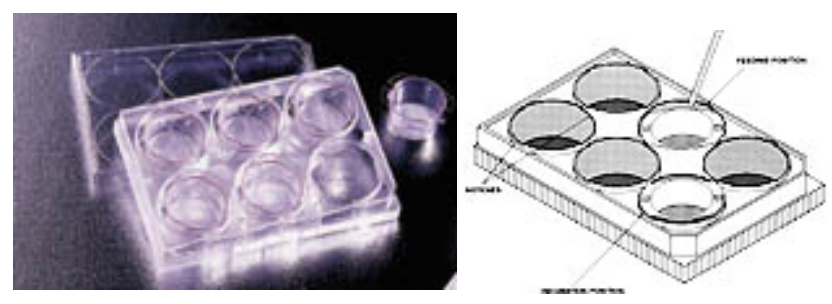

Figure 3. Cell Culture Inserts (BD Falcon) 


\section{Speciation modeling}

Lastly, the equilibrium speciation modeling was performed by means of Visual MINTEQ (v. 3.0, maintained by J.Gustafsson at KTH, Sweden, available at http://www.lwr.kth.se/English/OurSoftware/vminteq/ updated with the Nuclear Energy Agency's thermodynamic database for uranium) (23) to specify the predominant uranium species in aqueous media solutions that could be considered as possible inhibitors due to binding to negatively charged bacterial cell surfaces. The modeling was performed in the aqueous synthetic groundwater matrix amended with $0 \mathrm{mM}, 0.5 \mathrm{mM}, 2.5 \mathrm{mM}, 5 \mathrm{mM}$ $\mathrm{KHCO}_{3}$ concentrations. The $\mathrm{pH}$ of the solutions was measured after the completion of the experiment, and $\mathrm{U}(\mathrm{VI})$ data were collected following the inoculation of bacteria when $\mathrm{U}(\mathrm{VI})$ sorption reached its maximum. In bicarbonate-free solutions, a $\mathrm{CO}_{2}$ partial pressure $\left(p_{\mathrm{CO} 2}\right)$ was assumed to be $10^{-3.5}$ atm.

\section{Statistical Analysis}

All experiments were conducted in duplicate or triplicate to obtain descriptive statistics such as mean, standard deviation, and confidence interval of the mean. Where applicable, such as the experimental data for sorption isotherm, relationships were modeled and evaluated with least squares regression analyses. Uranium calibration standards (SPEX certiPrep), blanks, and check standards (95-105\% recovery) were analyzed for quality control before each experiment utilizing the KPA to check the variability of the machine. A comparison between specific experimental $\mathrm{K}_{\mathrm{d}}$ values against soil of the study area was investigated using a one sample t-test. Results with multiple experimental groups and independent factors, such as the study on the effects of U(VI) uptake due to different bicarbonate and uranium concentrations, were examined with ANOVA statistics. The 
Holm-Sidak multiple comparison test was performed when significant differences were found between samples; this is a more powerful test than the Turkey and Bonferroni tests and its recommended as the first line procedure. All statistical tests were carried out by Sigma plot 11.2 (Systat Software Inc). Significant levels were set to $\alpha=0.05$. 


\section{RESULTS AND DISCUSSION}

\section{Assessment of Arthrobacter strains growth}

Uranium sorption and autunite leaching experiments require knowledge of the growth profile and tolerance to uranium of the individual bacterial strain obtained from the SMCC. The nature of bacteria to multiply its numbers in an exponential growth pattern makes it very important to quantify their growth rate in response to changes in environmental conditions; failure to do so would result in an additional dependent variable in future experiments. The 5\% PYTG media used in our experiments provided the bacteria with all the necessary nutrients for growth and metabolism, creating the ideal growth conditions for studying any particular phenomena using the cultivation- based time-dependent approach. The increase in cell density was calculated over a period of seven days using a hemocytometer (Figure 4). The results confirmed the typical exponential growth pattern for bacteria.
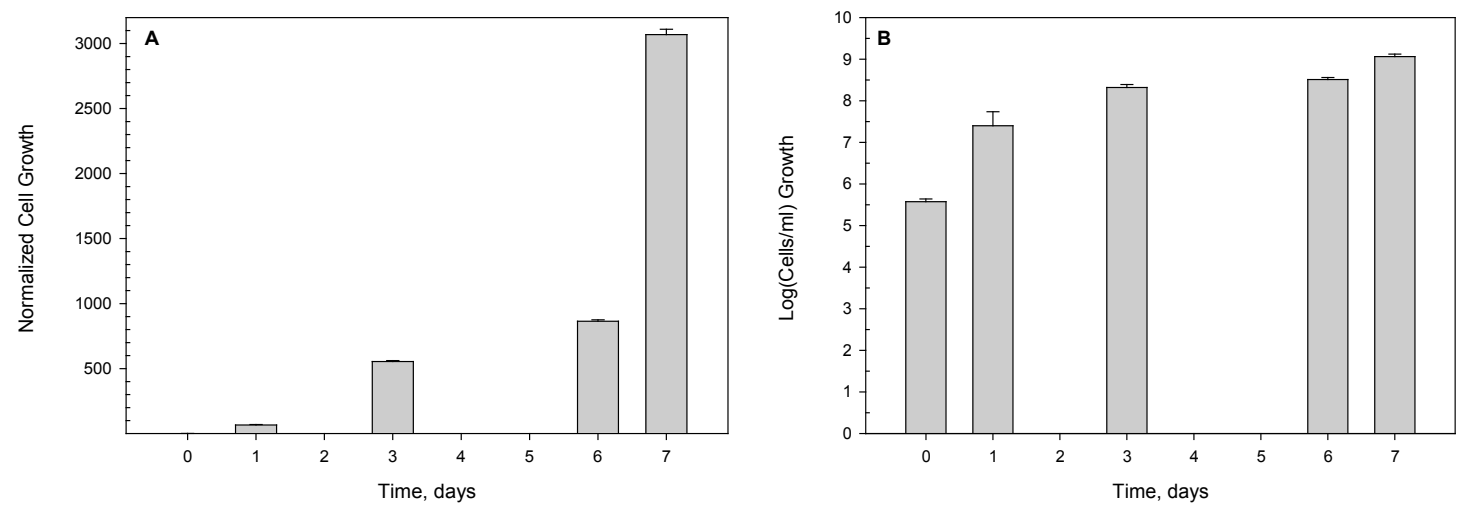

Figure 4. Growth for Athrobacter strain G975 over 7 days in HEPES buffered PYTG $5 \%$. A) Cell growth normalized to their initial cell number. B) Cell density, Log cell $/ \mathrm{ml}$, over time $(n=2)$. 


\section{Assessment of Arthrobacter sp. G975 resistance to uranium (VI)}

Wet chemistry, microscopic, and microbiological methods were used to elucidate the resistance mechanisms of Arthrobacter G975 isolate to U(VI) and determine the highest tolerable concentration of uranium for this strain while still remaining viable. The goal of the bacterial cultivation experiments carried out in 5\% PYTG liquid media amended with various concentrations of uranium was to determine the cell tolerance mechanism to U(VI), investigate time-dependent changes in viable cell numbers and prepare for the following uranium biosorption and autunite microbial leaching experiments.

Recording of $\mathrm{pH}$ values in the bacterial broth solution showed a decrease from 6.0-6.5 to 4.75-5.00 over a period of 7 days, which remained unchanged thereafter. By this time, the bacterial cell numbers exponentially increased and plateaued at approximately 8.6 $\log$ Cells $/ \mathrm{mL}$ or $7.1 \log \mathrm{CFU} / \mathrm{mL}$ (Figure 6, Figure 7). The decline in $\mathrm{pH}$ has been attributed to several factors: the addition of uranyl nitrate, a weak nitric acid solution, and bacterial activities that typically result in the production of acids when metabolizing

glucose. The accession of $20 \mathrm{ppm}$ and $30 \mathrm{ppm}$ of $\mathrm{U}(\mathrm{VI})$ caused the initial $\mathrm{pH}$ to drop from 6.5 to 5.5 and 6.5 to 5 , respectively. To prevent any adverse effects on cell viability due to the decline in $\mathrm{pH}$, the following experiments were conducted with media augmented with HEPES buffer $(0.1 \mathrm{M}, \mathrm{pH} 7.2)$ in a quantity of $10 \mathrm{~mL} / \mathrm{L}$; this amount was found sufficient in preventing acidification of the culture broth (Figure 5). 


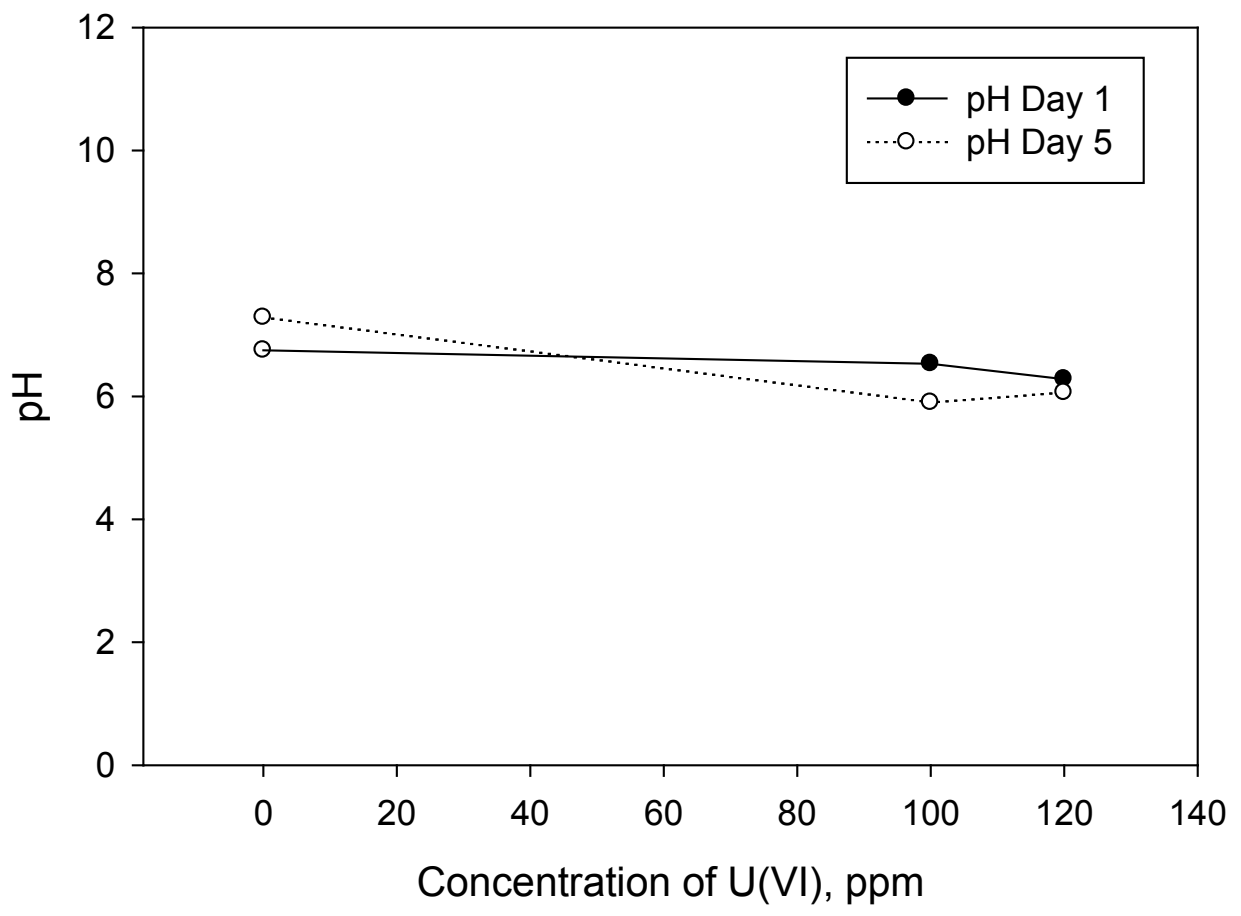

Figure 5. $\mathrm{pH}$ changes in bacterial broth solutions spiked with U(VI). G975 at 0, 100, \&120ppm of U(VI), 5\% PTYG media buffered with HEPES

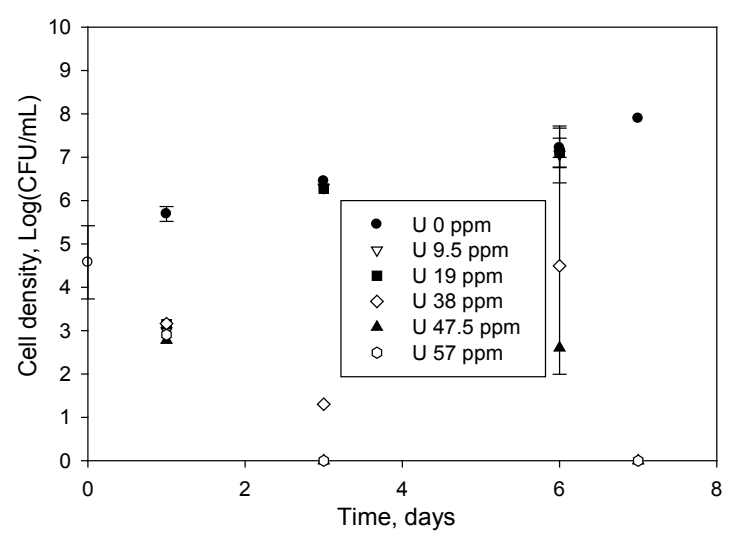

Figure 6. Changes in colony forming units of G975 over 7 days period in the presence of $\mathrm{U}(\mathrm{VI})(\mathrm{n}=3)$.

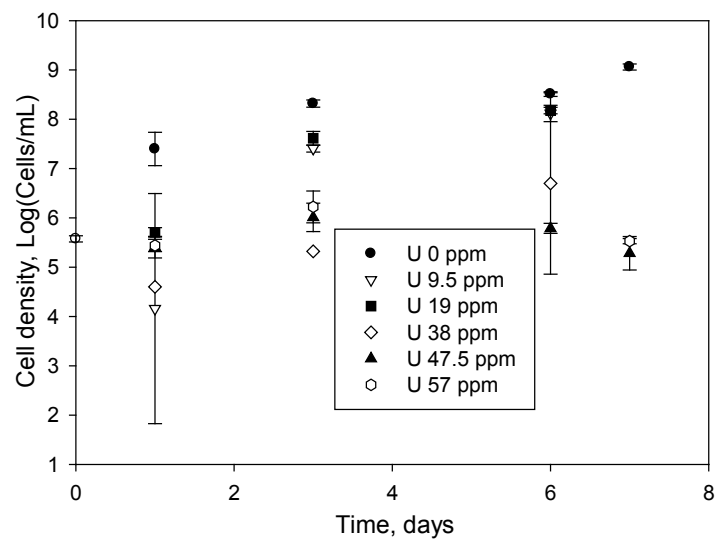

Figure 7. Changes in G975 density over 7 days period in the prescence of $\mathrm{U}(\mathrm{VI})(\mathrm{n}=3)$. 
Cell viability in control media without uranium, determined via colony forming units $\mathrm{cfu} / \mathrm{mL}$, ranged from $4.75 \pm 0.5 \log \mathrm{CFU} / \mathrm{mL}$ at the beginning of the experiment, to 7.89 $\log \mathrm{CFU} / \mathrm{mL}$ for G975 over 7 days of cultivation. The mean population density for the same period changed from $5.6 \log$ cells $/ \mathrm{mL}$ to $9 \log$ cells $/ \mathrm{mL}$. With the addition of uranium to the cultivation media, the bacteria tolerance changed, and the viability of the cells was inhibited under the influence of high uranium concentrations. G975 exhibited a high tolerance towards $\mathrm{U}(\mathrm{VI})$, remaining viable in the presence of 9.5-19 ppm of $\mathrm{U}(\mathrm{VI})$ over the study period. The cell density and CFU counts of viable colonies were increased to values comparable to the control without uranium. G975 was capable of tolerating up

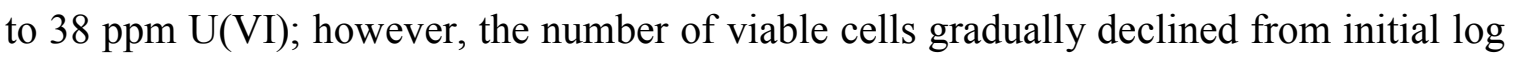
$4 \mathrm{cfu} / \mathrm{mL}$ to zero over 6 days (Figure 6 ). A decline in growth was observed for cultures amended with 48-57 ppm of U(VI), and no viable colonies were detected on day 3 . The decrease in CFU counts did not appear to be due to cell lysis, as the initial cell density determined by direct microscopy remained unchanged over the study period (Figure 7). Experiments conducted with a smaller initial concentration of cells, 100,000 cells $/ \mathrm{mL}$ ( 5 $\log$ cells $/ \mathrm{mL}$ ), showed less viable cells compared to experiments with higher cell counts for a given uranium concentration. Thus, the cell viability is dependent on the initial concentration of cells. This finding is compatible with Tsuruta's (45) results; he found that the relative amount of uranyl ion adsorbed per cell was decreased with increasing cell density and hypothesized that the lower relative concentrations of $U$ could enhance cellular survival in the presence of toxic substances.

After $\mathrm{U}(\mathrm{VI})$ exposure, the colonies observed on the plates were small in diameter, uniformly circular, entire, and smooth on the agar surface. The G975 strain exhibited the 
rod-coccus growth cycle. The G975 colonies were golden in color. Control samples taken from the bacterial broth without dilution formed large areas of clusters when cultured on glucose media with CFUs not able to be counted. All of these morphological properties are consistent with those described for the genus Arthrobacter (61).

Culture media components are readily degradable by microorganisms; therefore, a reduction in TOC consumption indicates a significant inhibition to the microbial activity. Measurements of centrifuged supernatant solutions in control tubes inoculated with Arthrobacter showed, by day 7, a decrease in the total organic carbon (TOC) content. The initial TOC value of $1014 \pm 56 \mathrm{mg} / \mathrm{L}$ was reduced by $40.7 \%$ for G975. The bacteria degraded TOC in the range of 30.7-34.7\% after the addition of 9.5-27 ppm of U(VI); but the addition of $38 \mathrm{ppm}$ of $\mathrm{U}(\mathrm{VI})$ inhibited the organic carbon consumption to $16.95 \%$, and it remained as low as $4.8 \%$ in the presence of $48 \mathrm{ppm}$ (Figure 8). These results revealed that the cell metabolism was altered by uranium, but the inhibitory effect was concentration-dependent. Triggered by the addition of U(VI) to the media, a decrease in TOC consumption was found for the G975 strain, consistent with the loss in cell viability (Figure 6 \& Figure 7).

When exploring the effects of bicarbonate on a separate experiment where the cells are exposed to $20 \mathrm{ppm} \mathrm{U}(\mathrm{VI})$, the initial TOC value of $818.8 \pm 59 \mathrm{mg} / \mathrm{L}$ in the fresh $5 \%$ PTYG media was reduced in U-free samples on average by $44-52 \%$ and $71-75 \%$ for $24 \mathrm{~h}$ and 48 h, respectively (Figure 9). However, in the presence of $20 \mathrm{ppm}$ of $\mathrm{U}(\mathrm{VI})$, the TOC degradation was less. Substantial inhibition was observed in bicarbonate-free samples resulting in only $14.0 \pm 1.2 \%$ and $36.8 \pm 2.8 \%$ reduction in TOC values over $24 \mathrm{~h}$ and $48 \mathrm{~h}$, respectively $(\mathrm{P}=<0.001)$. The addition of $5 \mathrm{mM}$ and $10 \mathrm{mM}$ of bicarbonate in the $\mathrm{U}(\mathrm{VI})$ - 
amended media increased the organic carbon consumption to $40.7 \pm 12.7 \%$ and $47.9 \pm 13.2 \%$ for $24 \mathrm{~h}$; it further increased to $67.2 \pm 19.3 \%$ and $73.7 \pm 22.9 \%$ for $48 \mathrm{~h}$ of uranium exposure, respectively. These results revealed that the cell metabolism was altered by uranium, but the inhibitory effect in the presence of bicarbonate was curtailed. Triggered by the addition of U(VI) to the media, a decrease in TOC consumption was found consistent with the loss in cell density.

Inhibition of bacteria activity appears to be associated with the binding of uranyl to the cell envelope. This finding correlates with Southam (2000) research who suggested that cell-surface associated mineralization results in limitations of nutrient transport and disruption of the proton motive forces. The passive binding of uranyl to cell surfaces reduces membrane fluidity and permeability, thus limiting media nutrient uptake. However, the presence of bicarbonate can strip uranyl from the cell surface by forming uranyl-carbonate complexes in solution (62).

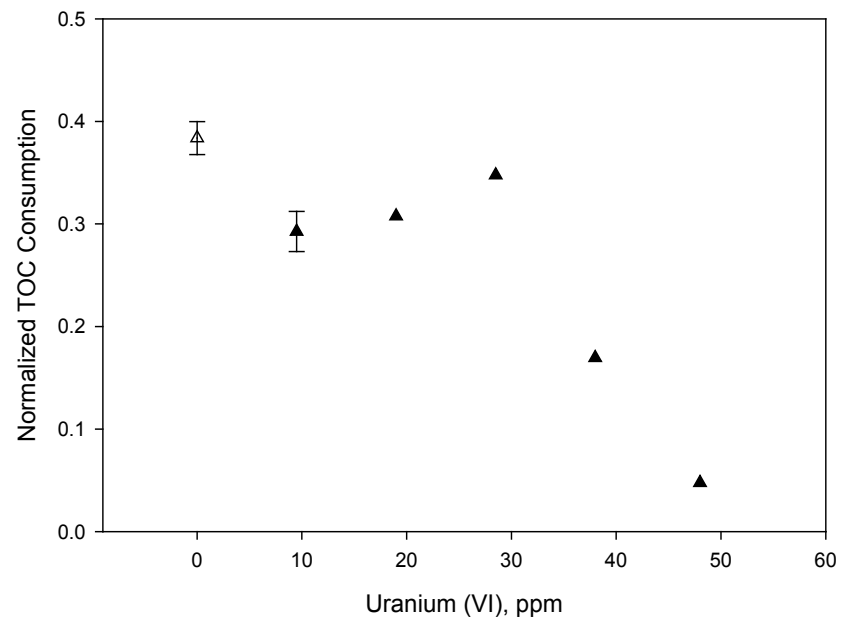

Figure 8. Organic substrate TOC consumption in the presence of U(VI) for Arthrobacter G975 (n=1) 


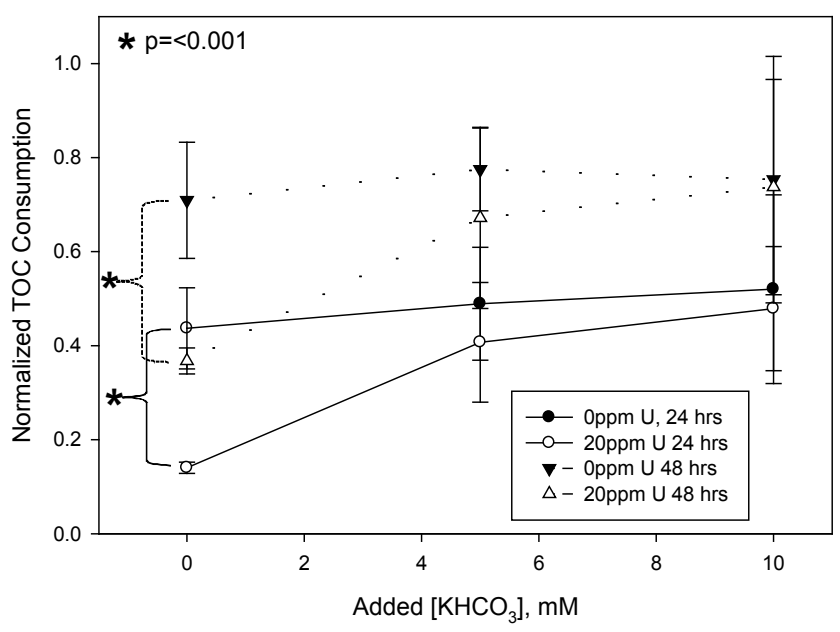

Figure 9. Time-depended changes in TOC consumption of Arthrobacter G975 cells grown in U(VI)-free and 20ppmU(VI) amended 5\%PTG media altered with $0 \mathrm{mM}, 5 \mathrm{mM}$, and $10 \mathrm{mM}$ of $\mathrm{KHCO}_{3}, \mathrm{pH} 7.3,25^{\circ} \mathrm{C}(\mathrm{n}=6)$.

\section{Correlation between bacterial mass and cell counts}

The execution of sorption equilibrium experiments requires the accurate weighing of cells used as a biosorbent in each batch test and a recording of each amount in mass units. However, such procedures do not account for cell numbers present in the batch reactors. For this purpose, as described in the methods section, we have experimentally derived the weight of a single Arthrobacter cell as $600 \pm 100 \mathrm{fg}$ for G975, which is comparable with value of $628 \pm 770 \mathrm{fg} / \mathrm{cell}$ obtained for E.Coli (63). The results presented in Figure 10 were obtained from bacteria in their exponential growth phase, which suggests that the actual weight of the cells can change once they enter the stationary phase. Results show 90\% linear correlations between cell mass and cell number for G975 bacterial strains, which allows for the prediction, with $<10 \%$ error, of the weight of bacteria based on the 
cell number used in future biosorption experiments. In addition, these values were used to account for uranium absorbance on the bacterial surface in SEM/EDS microscopic assay.

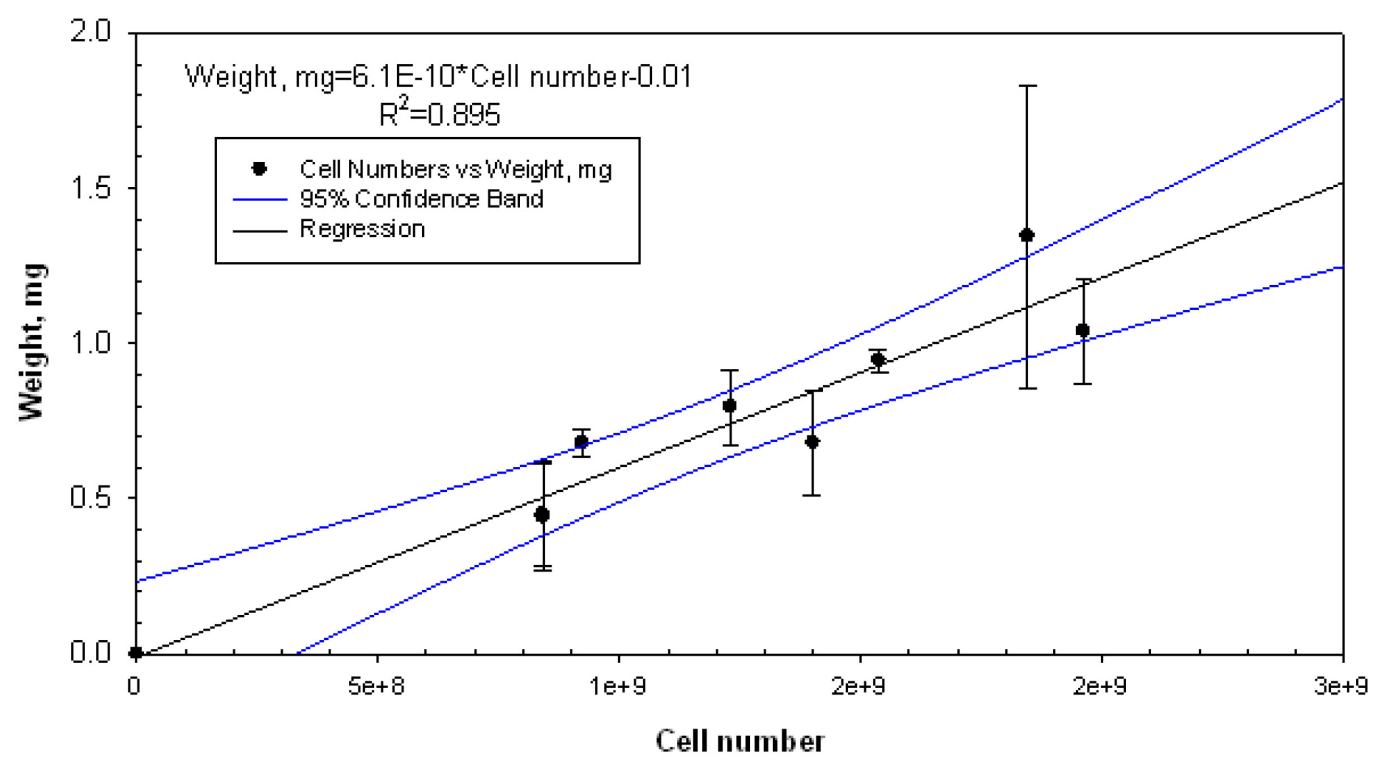

Figure 10. Correlation between weight vs. cell number for Arthrobacter G975 stain(n=2).

The recorded variations between experiments can be attributed to variations in size and shape of the studied strains. The ability of A. species to undergo marked changes in form during their growth was observed during the course of this study and confirmed with the literature (11). Cells can be rod shaped during the phase of exponential growth and cocci in their stationary phase; in addition, they can change from gram positive to gram variable. The morphology of G975 as observed under a light microscope, SEM, and AFM are shown in Figure 11. Some Arthrobacter cells are characterized by the formation of typical V-shaped pairs, this strain showed a brain-like surface area. 


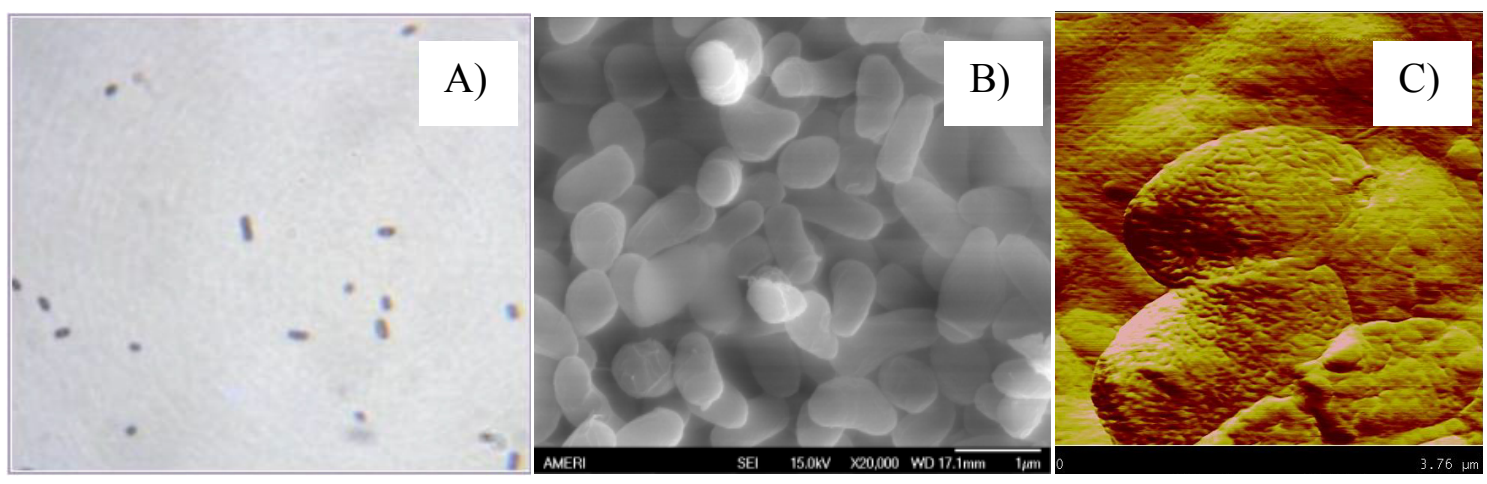

Figure 11. Morphology of G975. A) 100X magnification via light microscope. B) 20,000X magnification via SEM. C) $3.75 \mu \mathrm{m}^{2}$ area via AFM

\section{Visual MINTEQ speciation modeling}

The presence of bicarbonate can reduce the U(VI) toxicity by stripping uranyl from the cell surface and then forming uranyl-carbonate complexes in solution (62). This phenomena is supported by the results of the MINTEQA2 modeling of the speciation of uranium under the different treatments shown in Figure 12. Based on the modeling results, the species that undergoes the largest change in concentration due to added uranium at ambient $\mathrm{CO}_{2}$ levels, $0.229 \mathrm{mM}$, or due to added bicarbonate concentration at a constant uranium concentration, was $(\mathrm{UO} 2)_{3}(\mathrm{OH})^{5+}$. It is likely that toxicity in our experiments, in an open system where $\mathrm{CO}_{2}$ is allowed to equilibrate, is ruled by this species. The fact that it is a trimetric form of uranium, and that it is the most positive species, gives it the most potential to interact and damage negatively charged cells. The MINTEQA2 modeling of the $75 \mathrm{ppb} U$ vs. 20 ppm $U$ with increasing carbonate concentrations, shown in Figure 12, demonstrates how increasing the carbonate concentration in solution also increases the uranium-carbonate complexes, reducing the concentration of the total positive species. For carbonate concentrations of $0.2,2.7,5.2$, and $10.2 \mathrm{mM}$, with $20 \mathrm{ppm}$ of $\mathrm{U}$, the $\%$ of total uranium concentration in $\mathrm{CaUO}_{2}\left(\mathrm{CO}_{3}\right)_{3}{ }^{-2}$ 
species is $7.3,53.4,56.45,61.0$, respectively. Increased soluble bicarbonate concentrations makes free uranium ions less available to the negatively charged cells surface.
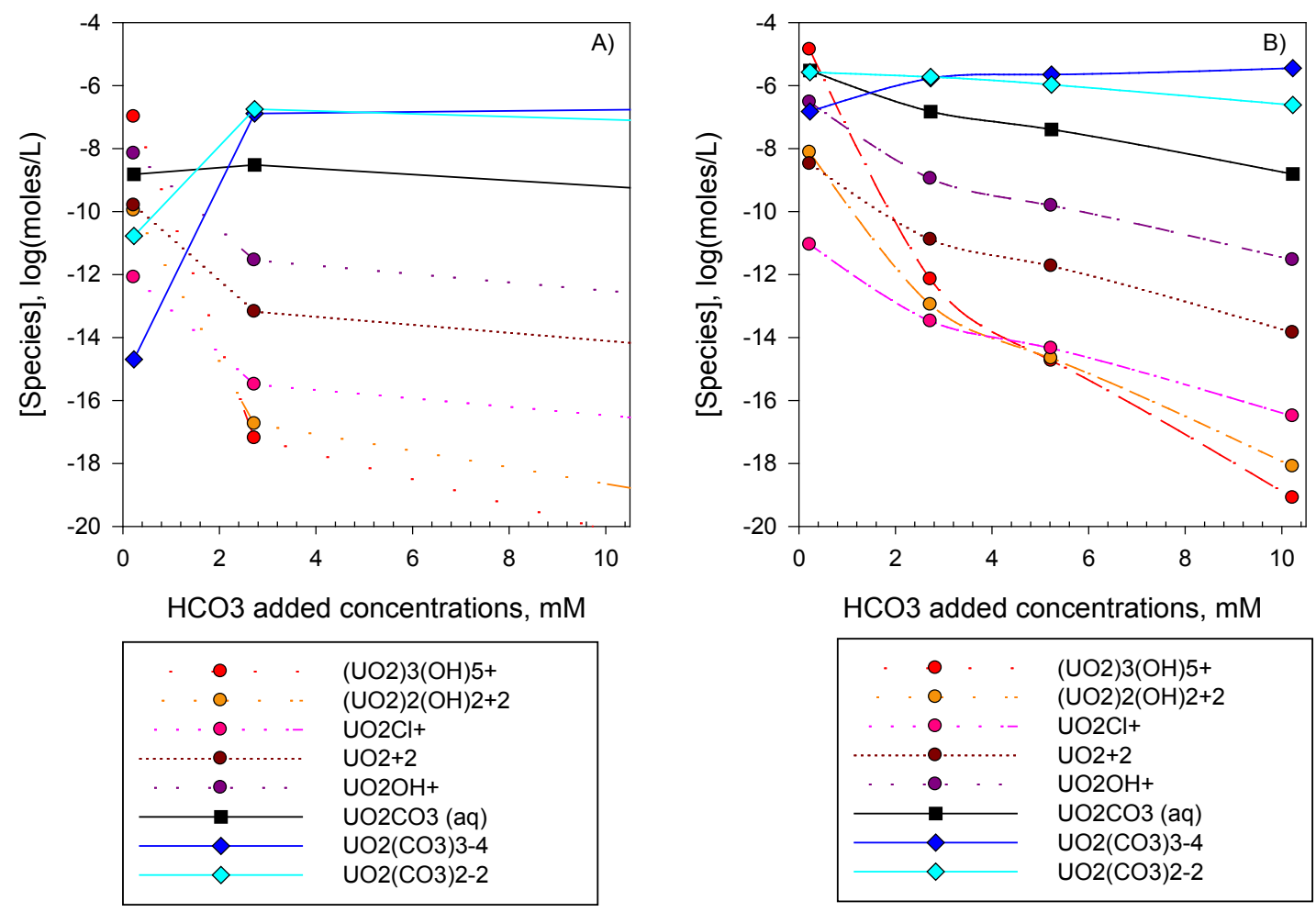

Figure 12. MINTEQA2 speciation modeling of U(VI) species vs. added bicarbonate concentrations. A) Low [U(VI)], 75ppb. B) High [U(VI)], 20ppm.

\section{U(VI) biosorption}

\section{Kinetics analysis}

The dry weight of bacteria was calculated indirectly from the cell count in their exponential growth phase by means of a hemocytometer based on the linear relationship shown in Figure 10. This relationship between cell numbers and dry cell weight is outlined in eq. $11\left(\mathrm{R}^{2}=0.90, \mathrm{n}=2\right)$. 


$$
\text { Dry cell weight }(\mathrm{mg})=\frac{6^{-10} \mathrm{mg}}{\text { Cell }} * \text { Number of Cells }
$$

The uptake rate of $\mathrm{U}(\mathrm{VI}), \frac{m g}{g * m i n}$, under various environmental conditions, provides insight on the mechanisms of bioadsorption and establishes the exposure time required for soluble U(VI) to reach sorption equilibrium, characterized by the unchanging U(VI) concentration in the solution.

Initial results for the G975 bacteria and uranium adsorption kinetics with carbonate-free SGW are shown in Figure 13. The results show that within the first 15 minutes, 29.09 $\pm 16.3 \%$ of the $\mathrm{U}(\mathrm{VI})$ was taken up by the cells following a linear relationship $\left(\mathrm{R}^{2}=0.99\right)$ with the rate of $99.53 \frac{\mu g}{L \mathrm{hr}}$. However, the large standard deviation for each sample does not reject the possibility of second order kinetics. Within 5.25 hours, $87.57 \pm 17.48 \%$ of the total uranium concentration was removed by the bacteria. Based on these results, we determined that the sampling process required continuing beyond 5.25 hours in order to determine if the process had reached equilibrium. Consequently, subsequent sorption kinetics samples were taken in 2-hour intervals up to 6 hours, followed by 24 and 48 hours. 


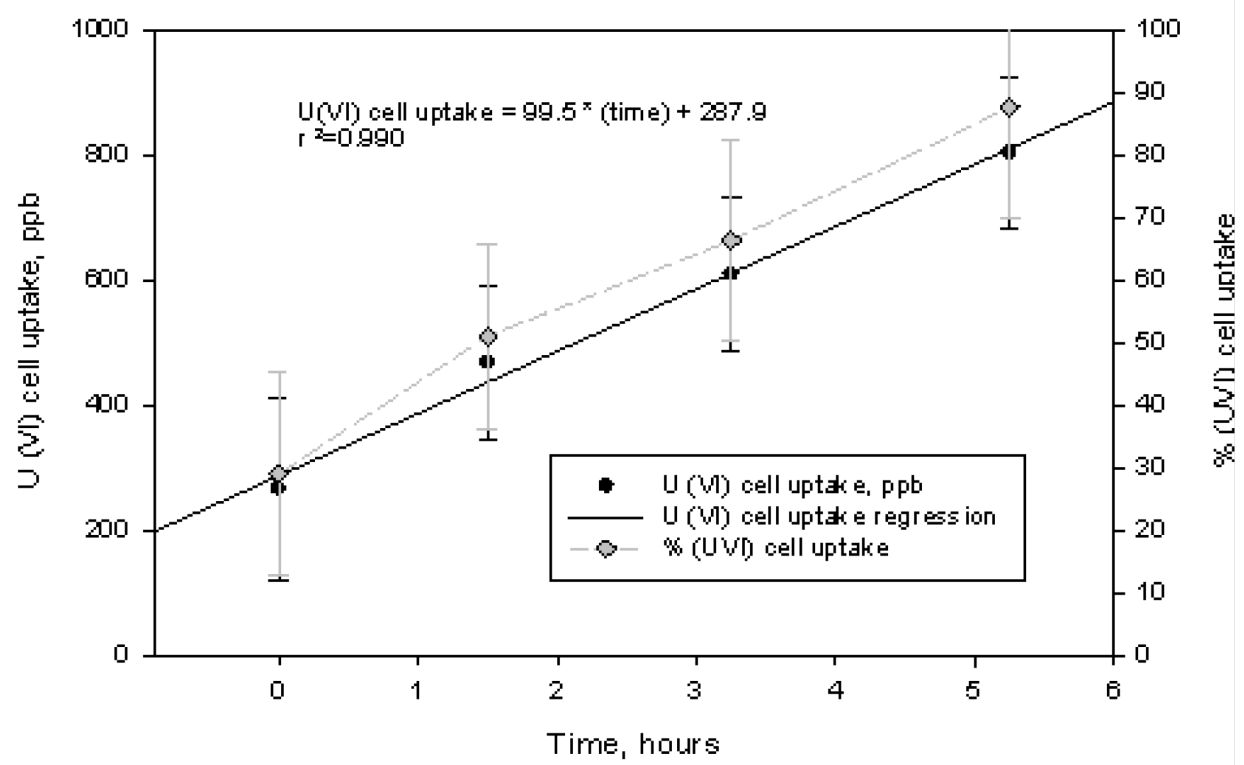

Figure 13. Preliminary results on biosorption kinetics using G975 strain with 917.2 $\pm 120.6 \mathrm{ppb}$ of initial U(VI) in CF-SGW; $(\mathrm{n}=3)$.

The bioadsorption experiments conducted with bicarbonate-free SGW solutions showed that Athrobacter sp. G975 can effectively remove soluble U(VI). In aqueous solutions at equilibrium with $\mathrm{CO}_{2}$ atmospheric pressure, the total uranium uptake by bacteria rises to $90 \pm 19 \%$ and $83 \pm 21 \%$ for low and high initial uranium concentrations, respectively. The system reached equilibrium at $24 \mathrm{~h}$ (Figure 14); however, U(VI) adsorption was noted $12-32 \%$ across the studied concentration range within the initial 25 minutes of bacterial exposure to uranium. 


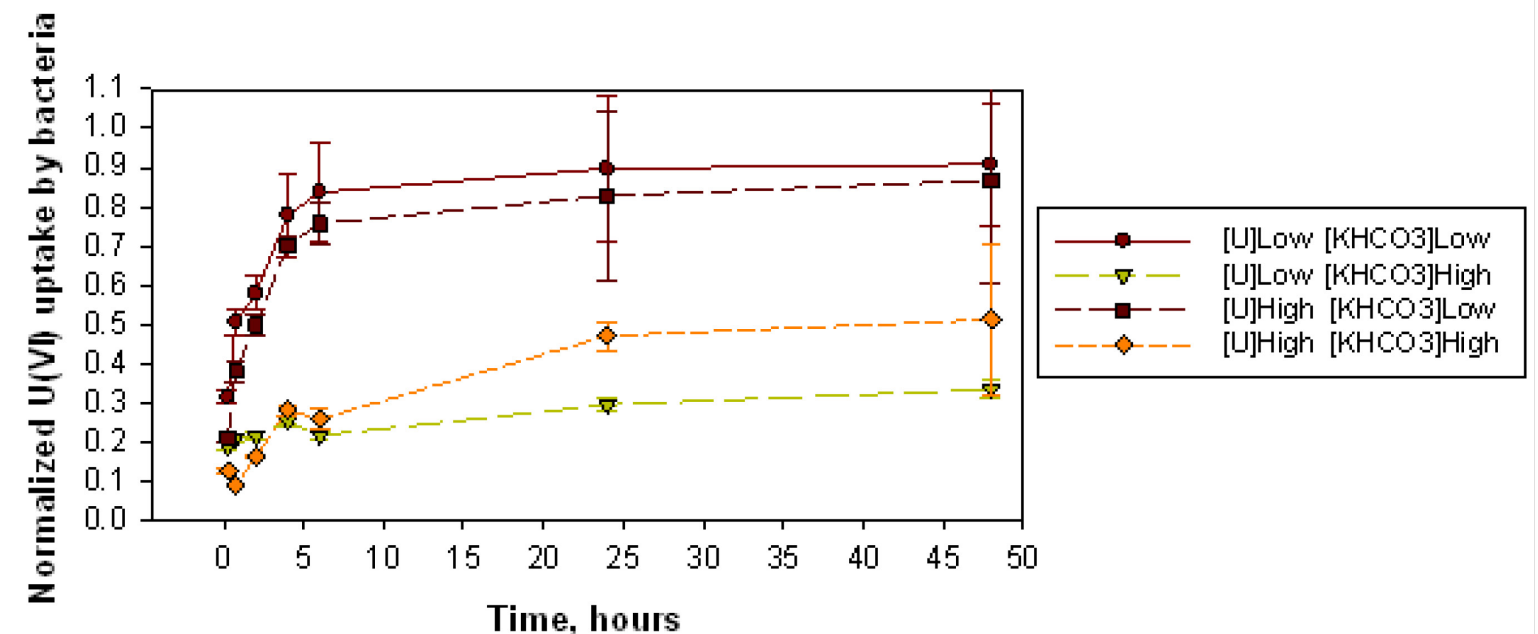

Figure 14. Percent of U(VI) uptake by Arthrobacter sp. G975 vs. Time, under low (0.3 ppm U(VI) and high (14.7 ppm U(VI)) concentrations of U(VI) and 0 and $2.5 \mathrm{mM}$ of bicarbonate in $\mathrm{SGW}, \mathrm{pH} 7.3,25^{\circ} \mathrm{C},(\mathrm{n}=3)$.

The system amended with $2.5 \mathrm{mM}$ of bicarbonate exhibited at equilibrium a significant decrease in bioadsorption to $47 \pm 4 \%$ at high initial concentration of U(VI), and with a more pronounced decrease to $30 \pm 2 \%$ in the systems with lower initial U(VI) concentrations. The low removal efficiency of U(VI) in the presence of competing ligands like carbonate is expected in these conditions considering the strong binding affinity of actinides toward carbonate ligands.

All bicarbonate-bearing experiments showed an increase of U(VI) adsorption by Arthrobacter sp. G975 within the first hour under all test conditions; however, after the initial fast uptake period, the process of U(VI) uptake was gradually slowed until it reached equilibrium at 24 hours (Figure 15). 


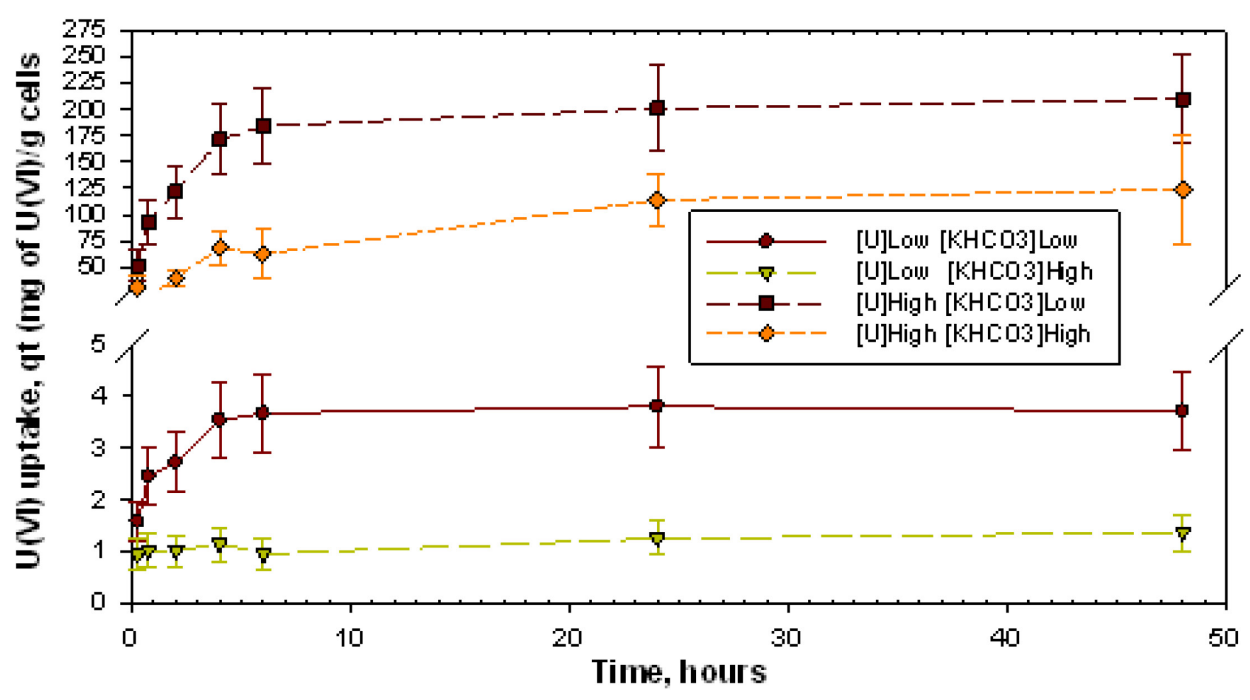

Figure 15. U(VI) uptake by Arthrobacter sp. G975 (mg/g) vs. Time, under low and high $\mathrm{U}(\mathrm{VI})$ concentrations and in bicarbonate amended SGW at $\mathrm{pH} 7.3,25^{\circ} \mathrm{C}$. Calculated values are based on the cells dry weight $(n=3)$.

Kinetics data analysis to interpret the experimental data and understand the controlling mechanisms of biosorption kinetics were conducted by means of the first-order, secondorder, and the pseudo-second-order kinetic models (54)(53). Only the pseudo-secondorder model could delineate our results with very little error; its equation is expressed as:

$$
\begin{gathered}
\mathrm{dq}_{\mathrm{t}} / \mathrm{d}_{\mathrm{t}}=\mathrm{k}_{2}\left(\mathrm{q}_{\mathrm{e}}-\mathrm{q}_{\mathrm{t}}\right)^{2} \\
\text { Integrating leads to } \\
{\left[1 /\left(\mathrm{q}_{\mathrm{e}}-\mathrm{q}_{\mathrm{t}}\right)\right]=\left(1 / \mathrm{q}_{\mathrm{e}}\right)+\mathrm{k}_{2} \mathrm{t}} \\
\text { Or } \\
\left(\mathrm{t} / \mathrm{q}_{\mathrm{t}}\right)=\left(1 / \mathrm{k}_{2} \mathrm{q}_{\mathrm{e}}{ }^{2}\right)+\left(1 / \mathrm{q}_{\mathrm{e}}\right) \mathrm{t}
\end{gathered}
$$

Where $\mathrm{q}_{\mathrm{e}}$ is the equilibrium adsorption capacity, $\mathrm{q}_{\mathrm{t}}$ represents the adsorption capacity of time $\mathrm{t}(\mathrm{mg} / \mathrm{g})$. The plot of $\mathrm{t} / \mathrm{q}_{\mathrm{t}}(\mathrm{mg} / \mathrm{g})$ against time, $\mathrm{t}$, gave a linear relationship and the $\mathrm{k}_{2}$ and $\mathrm{q}_{\mathrm{e}}$ was obtained from the intercept and slope, respectively (Figure 16). 


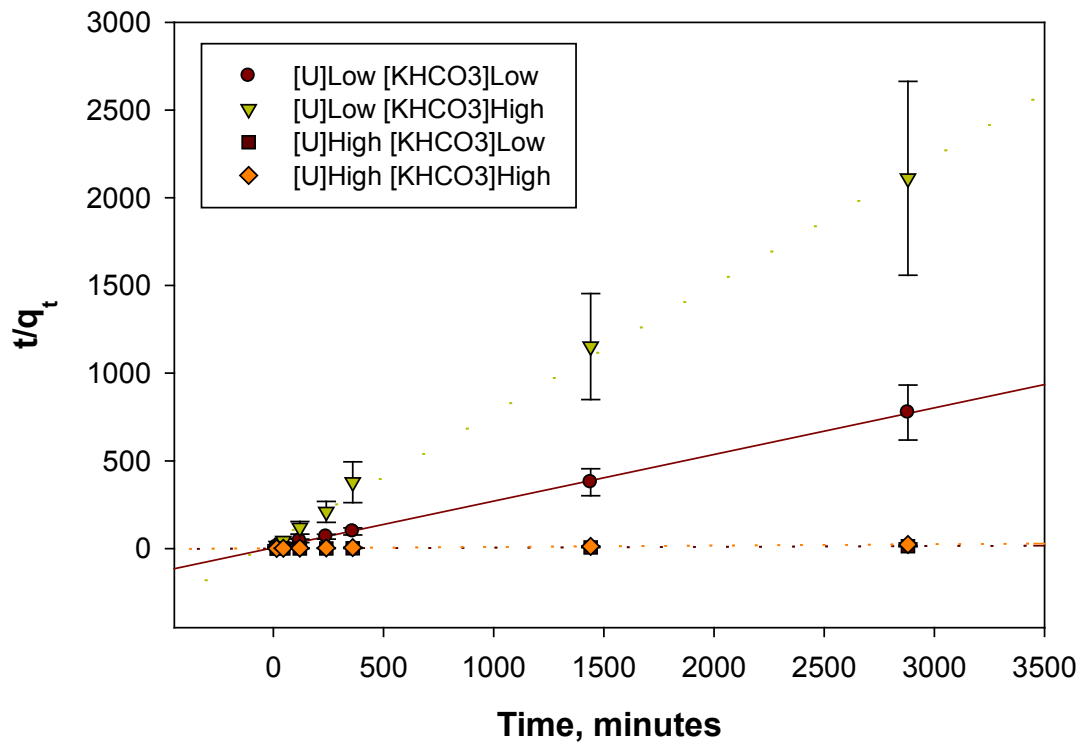

Figure 16. Pseudo second -order rate equation regressions for Athrobacter sp. G975, under low and high $\mathrm{U}(\mathrm{VI})$ concentrations in bicarbonate amended $\mathrm{SGW}$ at $\mathrm{pH} 7.3,25^{\circ} \mathrm{C}$, $(n=3)$.

The model provides a good fit to the observed adsorption behavior in the bicarbonatebearing experiments over the $\mathrm{U}(\mathrm{VI})$ concentrations tested. The correlation coefficient $\left(\mathrm{R}^{2}>0.991\right)$ adequately describes the kinetics of uranium biosorption by the bacteria and the U(VI) uptake rates determined by the model agree very well with the experimental data shown in Table 2. In addition, the theoretical $\mathrm{q}_{\mathrm{eq}}$ values were in accordance with the experimental $\mathrm{q}_{\mathrm{eq}}$ values. From these two facts, we can conclude that adsorption follows the pseudo second-order model with the assumption that biosorption may be the rate limiting step and the rate is proportional to the square of the number of unoccupied sites. 
Table 2. Pseudo 2nd-order model simulation sorption kinetic rates, $\mathrm{k}$ rate constant $(\mathrm{mgU}(\mathrm{VI}) / \mathrm{g} / \mathrm{min})$, and equilibrium adsorption capacity $(\mathrm{Qe}=\mathrm{mgU}(\mathrm{VI}) / \mathrm{g})$ for Arthrobacter $\mathrm{sp}$.

G975 in carbonate amended SGW at $\mathrm{pH} 7.3,25^{\circ} \mathrm{C},(\mathrm{n}=3)$.

\begin{tabular}{|c|c|c|c|}
\hline \multicolumn{2}{|c|}{ Pseudo $2^{\text {nd }}$ Order } & \multicolumn{2}{|c|}{ Factor B } \\
\hline$\frac{d Q}{d t}$ & $\begin{array}{l}\text { to } 2^{\text {nd }} \text { Order } \\
k\left(Q_{e}-Q_{t}\right)^{2} \\
\frac{1}{k Q_{e}^{2}}+\frac{t}{Q_{e}}\end{array}$ & $\begin{array}{c}{\left[\mathrm{KHCO}_{3}\right]} \\
\text { Low } \\
0 \mathrm{mM}\end{array}$ & $\begin{array}{c}{\left[\mathrm{KHCO}_{3}\right]} \\
\text { High } \\
2.5 \mathrm{mM}\end{array}$ \\
\hline \multirow{2}{*}{ 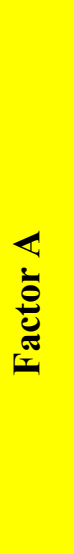 } & $\begin{array}{c}\text { [U(VI)] Low } \\
299.1 \mathrm{ppb}\end{array}$ & $\begin{array}{c}\mathrm{k}=0.014 \pm 0.01 \\
\mathrm{Q}_{\mathrm{e}}=3.76 \\
\left(\mathrm{R}^{2}=0.997\right)\end{array}$ & $\begin{array}{c}\mathrm{k}=0.012 \pm 0.01 \\
\mathrm{Q}_{\mathrm{e}}=1.37 \\
\left(\mathrm{R}^{2}=0.997\right)\end{array}$ \\
\hline & $\begin{array}{l}\text { [U(VI)] High } \\
14,721.4 \mathrm{ppb}\end{array}$ & $\begin{array}{c}\mathrm{k}=7.16 \mathrm{E}-5 \pm 1 \mathrm{E}-5 \\
\mathrm{Q}_{\mathrm{e}}=213.7 \\
\left(\mathrm{R}^{2}=1\right)\end{array}$ & $\begin{array}{c}\mathrm{k}=3.24 \mathrm{E}-5 \pm 8 \mathrm{E}-6 \\
\mathrm{Q}_{\mathrm{e}}=132.6 \\
\left(\mathrm{R}^{2}=0.991\right)\end{array}$ \\
\hline
\end{tabular}

\section{$2^{2}$ Factorial design uranium sorption at equilibrium}

The results from the three-factors factorial design experiment indicated that the efficiency of the bioadsorption process is strongly dependent on the initial U(VI) concentrations, the concentrations of bicarbonate in the solution and time. The trend effect on the U(VI) adsorption by bacterial cells for each of the factors is shown in Figure 17. 

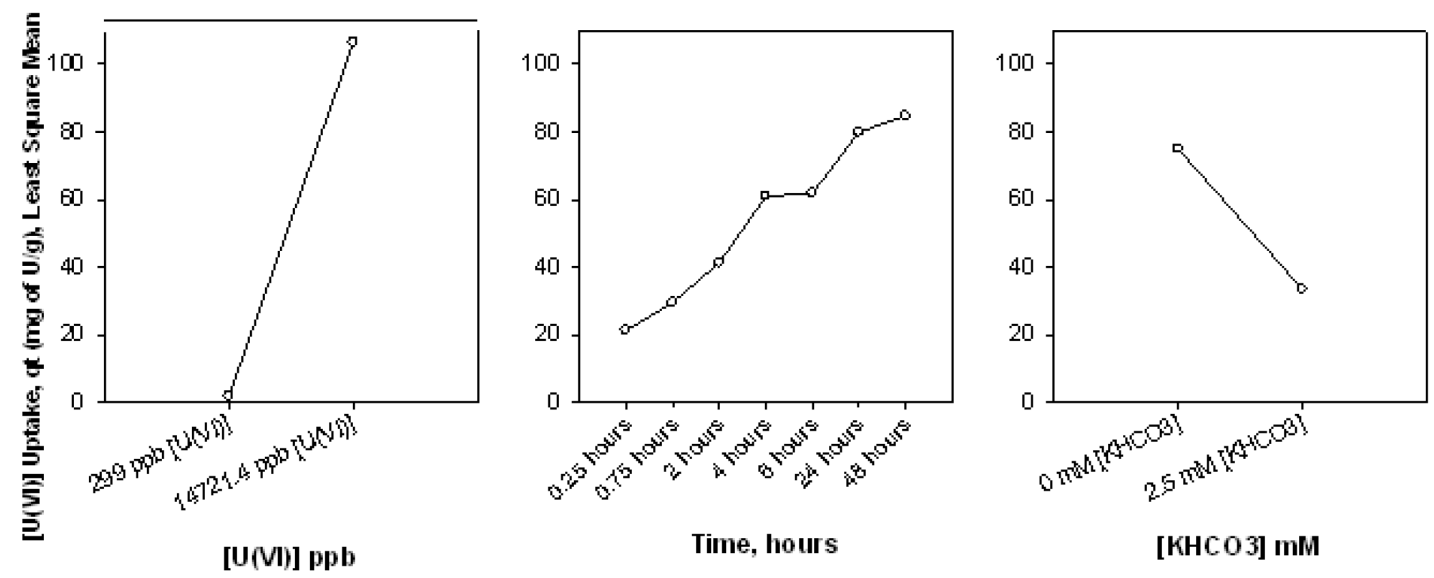

[KHCO3] mM

Figure 17. Profile plots derived from the factorial design experiment; least square means of $\mathrm{U}(\mathrm{VI})$ uptake $(\mathrm{mg} / \mathrm{g})$, time, and $\mathrm{HCO}_{3}$ concentrations.

The plots present sharp changes in the metal uptake, which increases directly proportional to the initial $\mathrm{U}(\mathrm{VI})$ concentration, and inversely proportional to the bicarbonate concentration in solution. As bacterial exposure time increases, the metal uptake follows smoothly. The 2-Way ANOVA statistical analysis at equilibrium, shown in Table 3, concludes that both the uranium initial concentration and the bicarbonate concentration are statistically significant factors that control the response variable of metal uptake $(p<0.001$, Power=1). Because the interaction between uranium and bicarbonate concentrations is also statistically significant, knowing the main effects may have little practical meaning. However, the response variable can still be successfully predicted with the regression model representation of the two factor factorial experiment, revealed in Table 3, whose parameters are estimates related to the effect of the factors. The non-linear response surface plot $^{1}$ obtained from the model describing the U(VI) and

\footnotetext{
${ }^{1}$ A missing sample for high uranium and high bicarbonate was replaced by the mean substitution method.
} 
bicarbonate interactions at equilibrium is in agreement with the experimentally derived data $\left(\mathrm{R}^{2}=0.995\right)$ (Figure 18)(64).

Table 3. Two Way ANOVA: Effects of U(VI) and bicarbonate concentrations on the uranium uptake by Arthrobacter sp. G975 at equilibrium (24 hours), in SGW pH 7.3, $25^{\circ} \mathrm{C}$.

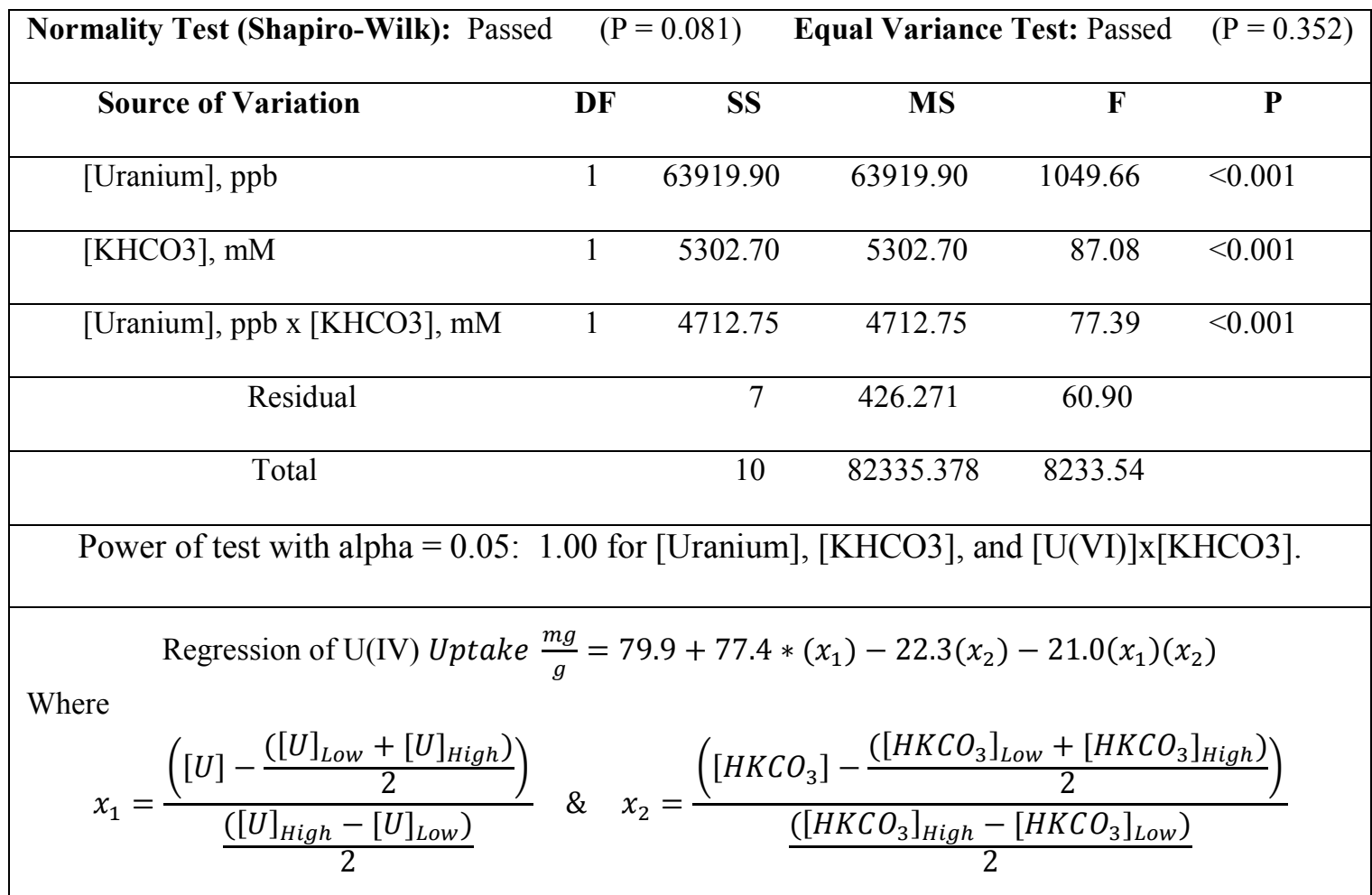




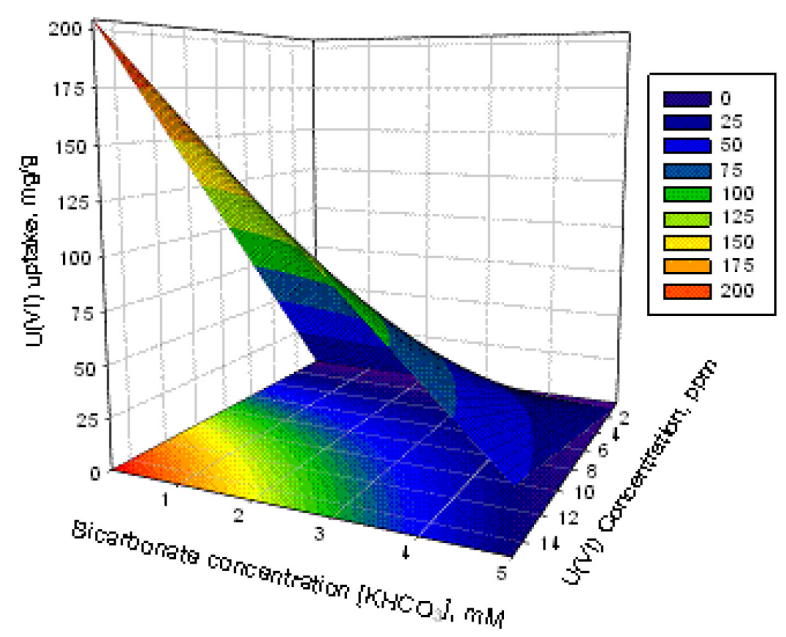

Figure 18 Response surface model, Arthrobacter sp. G975 uranium uptake (mg/g) vs. $\mathrm{U}(\mathrm{VI})$ and bicarbonate concentrations at equilibrium (24 hours), in SGW, $\mathrm{pH} 7.3,250 \mathrm{C}$.

\section{Sorption isotherm}

To examine the relationships between the bacteria adsorbed (q) and equilibrium concentrations $\left(\mathrm{C}_{\mathrm{e}}\right)$ in solution, the Langmuir, Freundlich, and linear isotherms were fitted to the experimental data of different bicarbonate concentrations. It is generally observed that as the concentration of a species in solution increases, the amount of it sorbed to contacting surfaces also increases (17). The different models are illustrated in Figure 19, Figure 20, and Figure 21. Biosorption isotherms may exhibit an irregular pattern due to the complex nature of both the sorbent material and its varied multiple active sites, as well as the complex solution chemistry of some metallic compounds (33). The results presented here strongly suggest that linearity prevails in the equilibrium relationship between adsorbed and solution concentrations for the entire range of initial U(VI) and bicarbonate concentrations studied. 


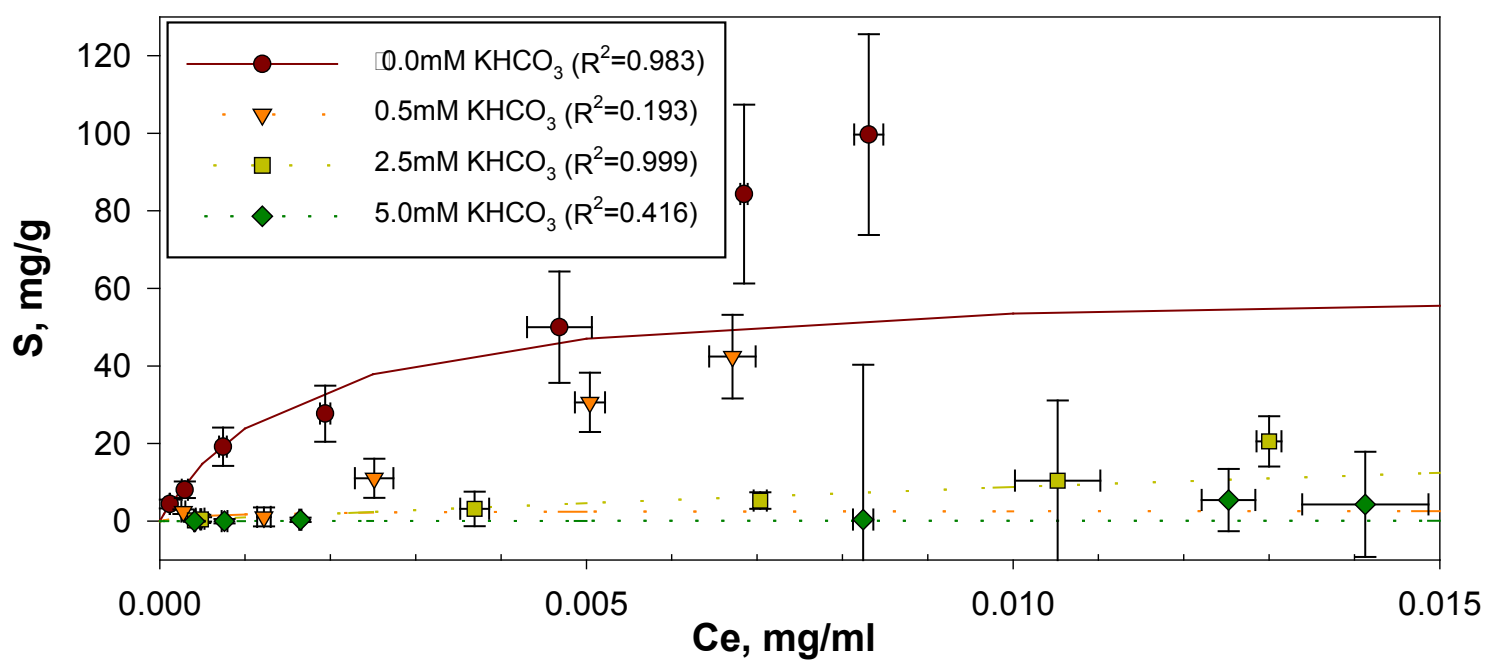

Figure 19. Calculated Langmuir U(VI) biosorption isotherms of Arthrobacter sp. G975 with bicarbonate concentrations varying in $\mathrm{SGW}$ from 0.0 to $5 \mathrm{mM}$ at $\mathrm{pH} 7.3,25^{\circ} \mathrm{C}, 24$ hours $(\mathrm{n}=3)$.

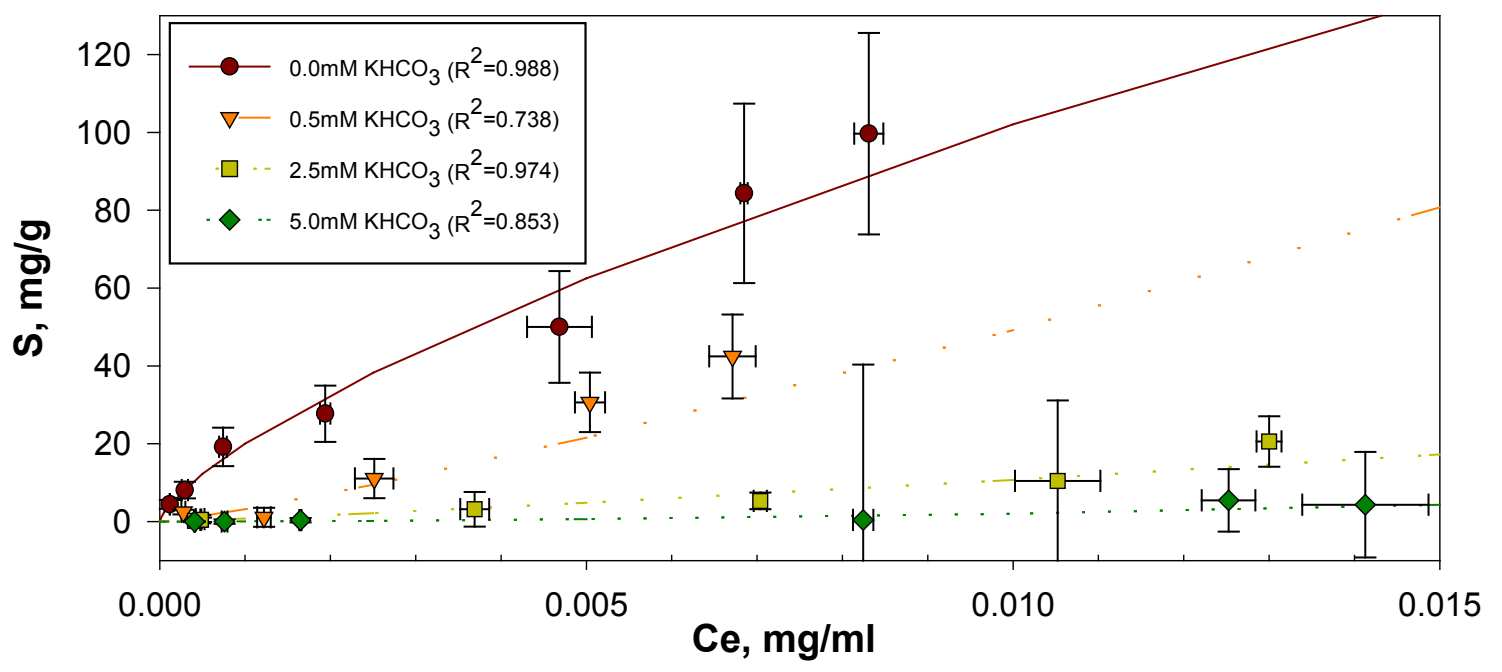

Figure 20. Calculated Freundlich U(VI) biosorption isotherms of Arthrobacter sp. G975 with bicarbonate concentrations varying in $\mathrm{SGW}$ from 0.0 to $5 \mathrm{mM}$ at $\mathrm{pH} 7.3,25^{\circ} \mathrm{C}, 24$ hours $(n=3)$. 


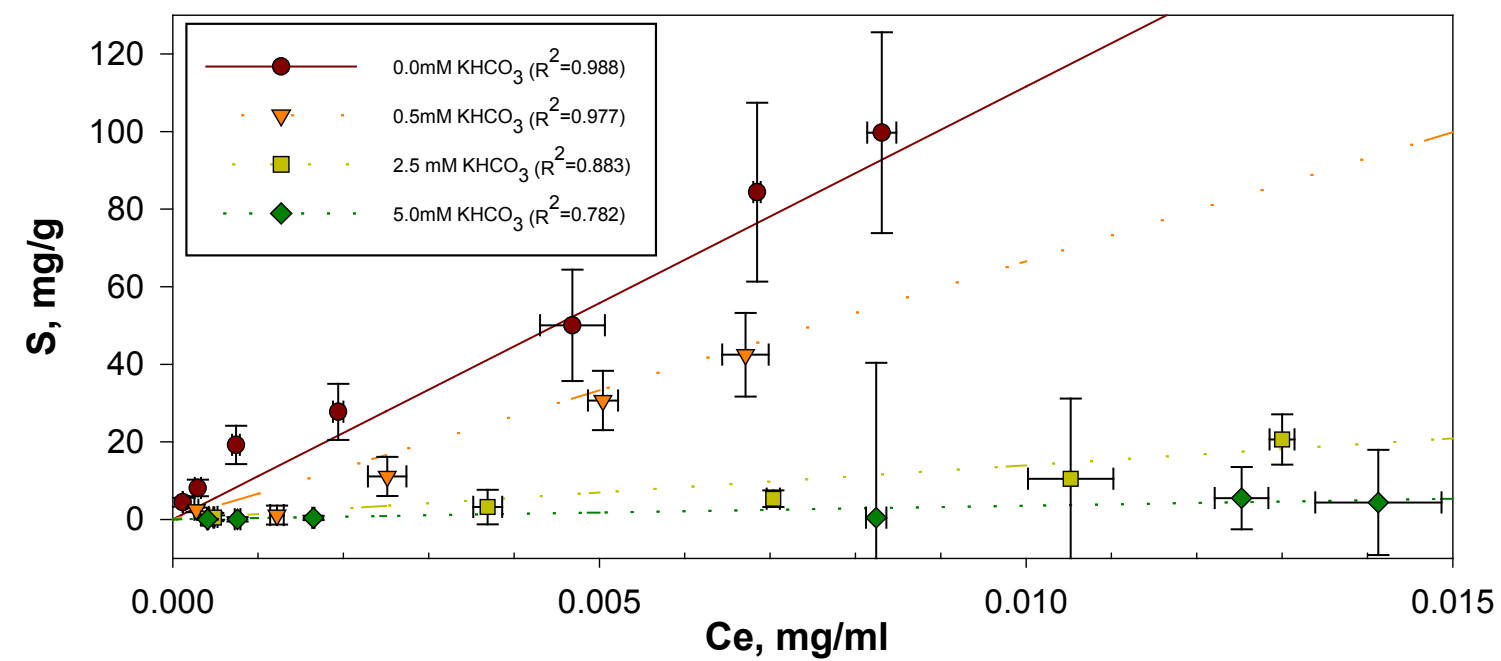

Figure 21. Calculated Linear U(VI) biosorption isotherms of Arthrobacter sp. G975 with bicarbonate concentrations varying in $\mathrm{SGW}$ from 0.0 to $5 \mathrm{mM}$ at $\mathrm{pH} 7.3,25^{0} \mathrm{C}, 24$ hours $(n=3)$.

The linear isotherm model provides the closest fit to the experimental results. This observation is supported by the Freundlich model whose mean $n$ value of $0.93 \pm 0.3$ is close to 1 and indexes of determination are as high as those calculated for the linear isotherm. Because neither the linear nor the Freundlich isotherms provide an approximate of the maximum adsorption capacity of the bacterial surface, $\mathrm{S}_{\max }$, we attempted to obtain the estimate from a regression of the data with the Langmuir isotherm model. The regression results show very low indexes of determination for all bicarbonate concentrations tested; that reaffirms the Linear isotherm as the best relationship to represent the equilibrium behavior of $\mathrm{U}(\mathrm{VI})$ based on the A.G975 strain used in this study. A summary of the results fitted to the simulated models are shown in Table 4 . The agreement of the data with the Linear isotherm and the low correlation for the Langmuir is conclusive. 
Table 4. Results for biosorption isotherms with Langmuir $\left(\mathrm{K}_{\mathrm{L}}\right)$, Freundlich $\left(\mathrm{K}_{\mathrm{F}}\right)$, and linear $\left(\mathrm{K}_{\mathrm{d}}\right)$ equations Arthrobacter sp. G975 at various bicarbonate concentrations in $\mathrm{SGW}, \mathrm{pH} 7.3,25^{\circ} \mathrm{C}, 24$ hours $(\mathrm{n}=3)$.

\begin{tabular}{|c|c|c|c|c|c|c|c|c|}
\hline $\begin{array}{c}\mathbf{K H C O}_{3}, \\
\mathbf{m M}\end{array}$ & $\begin{array}{c}\mathbf{K}_{\mathbf{L}}, \\
\mathbf{m L} / \mathbf{m g}\end{array}$ & $\mathbf{S}_{\mathbf{m a x}}$ & $\mathbf{R}^{\mathbf{2}}$ & $\mathbf{K}_{\mathbf{F}}, \mathbf{m L} / \mathbf{g}$ & $\mathbf{n}$ & $\mathbf{R}^{\mathbf{2}}$ & $\begin{array}{c}\mathbf{K}_{\mathbf{d}}, \\
\mathbf{m L} / \mathbf{g}\end{array}$ & $\mathbf{R}^{\mathbf{2}}$ \\
\hline 0 & $\begin{array}{c}624.0 \pm \\
205.6\end{array}$ & $\begin{array}{c}62.1 \pm \\
20.1\end{array}$ & 0.983 & $\begin{array}{c}2,660.7 \pm \\
79.2\end{array}$ & $\begin{array}{c}1.4 \pm \\
0.1\end{array}$ & 0.988 & $\begin{array}{c}11,161.0 \\
\pm 555.3\end{array}$ & 0.988 \\
\hline 0.5 & $\begin{array}{c}1,783.7 \\
\pm\end{array}$ & $\begin{array}{c}2.7 \pm \\
1.9\end{array}$ & 0.193 & $\begin{array}{c}11,803.2 \\
\pm 2,933.4\end{array}$ & $\begin{array}{c}0.8 \pm \\
0.3\end{array}$ & 0.738 & $\begin{array}{c}6,654.7 \pm \\
513.8\end{array}$ & 0.977 \\
\hline 2.225 .5 & $10.2 \pm$ & $95.2 \pm$ & 0.999 & $\begin{array}{c}2,119.3 \pm \\
153.6\end{array}$ & $\begin{array}{c}0.9 \pm \\
0.1\end{array}$ & 0.974 & $\begin{array}{c}1,394.7 \pm \\
253.3\end{array}$ & 0.883 \\
\hline 5 & 17.9 & 166.9 & $110.8 \pm$ \\
\hline 5 & $0.2 \pm$ & 0.416 & $\begin{array}{c}5,623.4 \pm \\
1,391.6\end{array}$ & $\begin{array}{c}0.6 \pm \\
0.1\end{array}$ & 0.853 & $\begin{array}{c}352.5 \pm \\
93.1\end{array}$ & 0.782 \\
\hline
\end{tabular}

The U(VI) adsorption capacity of A.G975 at equilibrium with atmospheric $\mathrm{CO}_{2}$ partial pressure and at an initial U(VI) concentration up to $14.5 \mathrm{mg} / \mathrm{L}$ was calculated as $150.2 \pm$ $71.4 \mathrm{mg} / \mathrm{g}$. This value is high compared with other bacterium like Bacillus sp. (38 mg/g) and low compared to other Citrobacter sp. (8000 mg/g) whose dry weight was not assessed and showed metal microprecipitates (33). We observed a decrease in the adsorption capacity in bicarbonate-bearing experiments similar to data derived from the factorial design experiments with the initial U(VI) concentrations ranging between 0.4-14 ppm. In fact, based on the $\mathrm{K}_{\mathrm{d}}$ values of the linear isotherm depicted in Figure 22, the adsorption capacity exponentially decays $\left(\mathrm{R}^{2}=0.99\right)$ as the bicarbonate concentration is increased in solution. We can, therefore, assume that there exists a limit close to $5 \mathrm{mM}$ of $\mathrm{HCO}_{3}$ at which point carbonate-bearing experiments exhibit little or no measurable loss of $\mathrm{U}(\mathrm{VI})$ due to sorption onto the bacterial surface. According to the EPA, when the $\mathrm{K}_{\mathrm{d}}$ value is greater than 5 , contaminants are less likely to leach or occur as surface runoff; 
the $\mathrm{K}_{\mathrm{d}}$ results for Arthrobacter G975 are very high, which means that uranium strongly adsorbs onto the microbes and should not move throughout the subsurface.

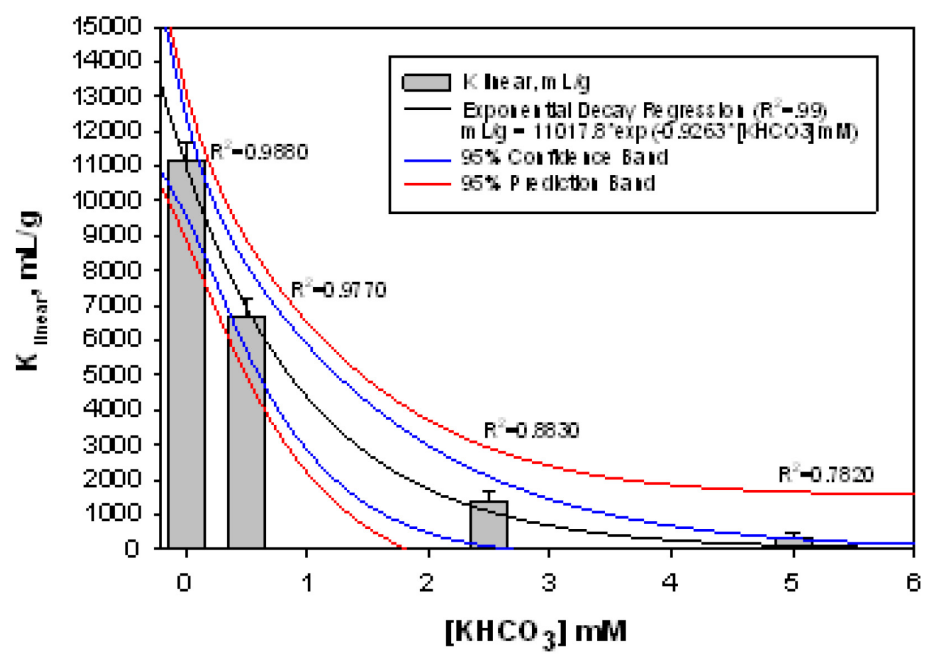

Figure 22. $\mathrm{K}_{\mathrm{d}}$ values from the linear isotherm of Arthrobacter sp. G975 with bicarbonate concentrations varying in $\mathrm{SGW}$ from 0.0 to $5 \mathrm{mM}, \mathrm{pH} 7.3,25^{\circ} \mathrm{C}, 24$ hours $(\mathrm{n}=3)$.

Further evidence of diminishing uranium uptake by bacteria under increasing carbonatebearing experiments is presented in Figure 23. The results strongly support the observation that the percent of $\mathrm{U}(\mathrm{VI})$ uptake is decreased with increasing concentrations of dissolved carbonate in the solution. 


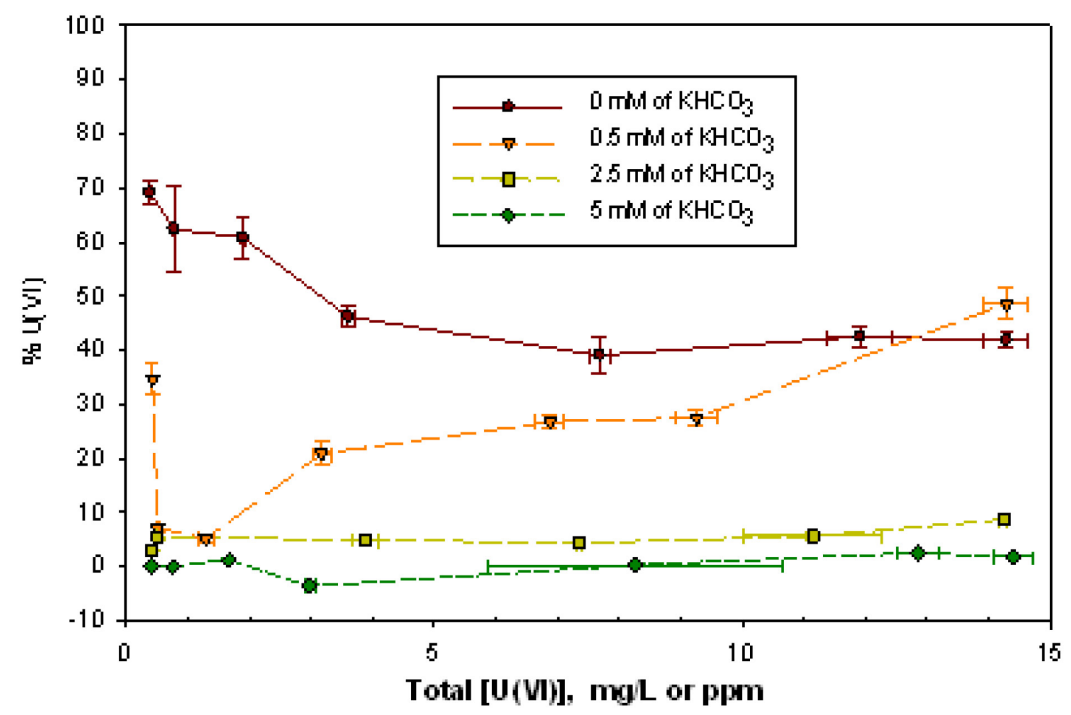

Figure 23. Percent of U(VI) uptake by Arthrobacter sp. G975 in SGW amended with bicarbonate concentrations varying from 0.0 to $5 \mathrm{mM}, \mathrm{pH} 7.3,25^{\circ} \mathrm{C}, 24$ hours $(\mathrm{n}=3)$.

In solutions without additional bicarbonate but at equilibrium with atmospheric $\mathrm{CO}_{2}$, $70 \%$ of $\mathrm{U}(\mathrm{VI})$ was removed by bacteria. The increase in initial $\mathrm{U}(\mathrm{VI})$ concentrations tend to diminish the percentage of $\mathrm{U}$ uptake to $40-50 \%$; however, this effect could be attributed to the $\mathrm{U}(\mathrm{VI})$ toxicity on bacterial cells. A pronounced decrease in percentage of $\mathrm{U}(\mathrm{VI})$ uptake by bacteria was originated from increasing bicarbonate concentrations in the SGW media. The addition of $5 \mathrm{mM}$ bicarbonate concentration yielded substantially lower values of bacterial uptake of $\mathrm{U}(\mathrm{VI})$, measured as $3 \%$. The biosorption process becomes considerably repressed in the presence of bicarbonate due to the formation of highly soluble and stable uranyl-carbonate and calcium uranyl carbonate complexes, $\mathrm{UO}_{2}\left(\mathrm{CO}_{3}\right)_{3}{ }^{4-}$ and $\mathrm{CaUO}_{2}\left(\mathrm{CO}_{3}\right)_{3}{ }^{2-}$. 


\section{Desorption experiments}

Desorption experiments were conducted to differentiate the amount of U(VI) externally adsorbed on the cell surface from that taken up by cells for internal accumulation. A 10 $\mathrm{mM} \mathrm{Na} \mathrm{N}_{2}$ EDTA washing solution, a strong complex forming agent, successfully released U(VI) from the cell surface.

The theoretical value of accumulated U(VI) inside the cell was calculated via mass balance. The results shown on Figure 24 revealed the presence of U(VI) accumulation inside the cell across the experimental range of studied U(VI) concentrations (0.4-14 ppm). The percentage of $\mathrm{U}(\mathrm{VI})$ uptake inside the cell was found comparable to the external accumulation on cells wall. The addition of $2.5 \mathrm{mM}$ of bicarbonate to the media solution resulted in limited biosorption and, as a consequence, accumulation inside the cell. Further studies on TEM/EDS microtome microscopy are required to identify uranium inside the bacteria. 

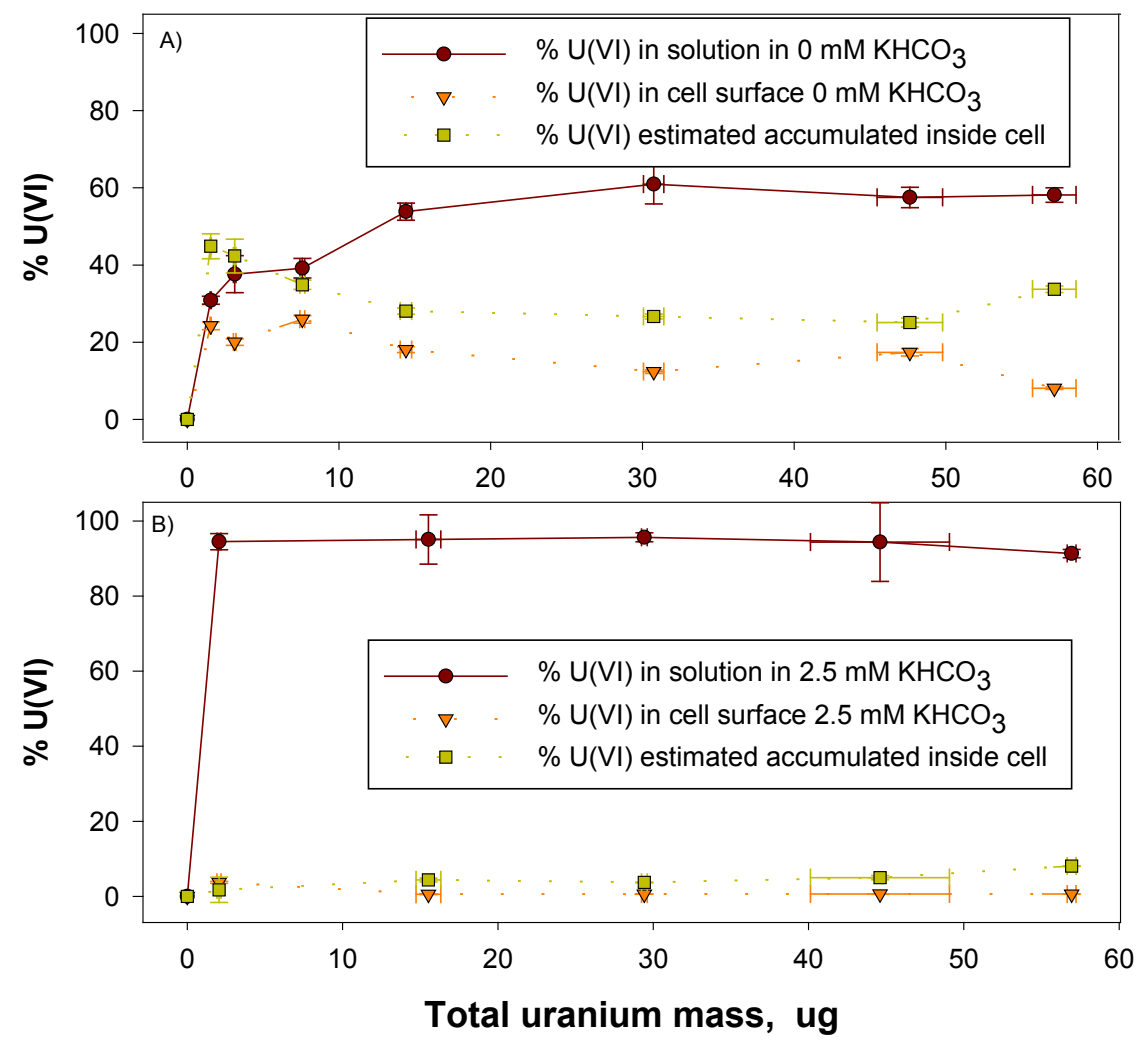

Figure 24. Calculated percentages of $\mathrm{U}(\mathrm{VI})$ distribution in SGW solution, adsorbed on bacterial cell, and accumulated inside cells. A) $0 \mathrm{mM}$ of added bicarbonate. B) $2.5 \mathrm{mM}$ of added bicarbonate concentration (at $\mathrm{pH} 7.3,25^{\circ} \mathrm{C}, 24$ hours) $(\mathrm{n}=3)$.

\section{Cell Viability}

We previously determined that Arthrobacter sp. G975 is able to withstand the toxic effects of uranium to concentrations up to $40 \mathrm{ppm}$ of $\mathrm{U}(\mathrm{VI})$. Cell viability was further evaluated through a $2 \times 2$ factorial design experiment with procedures previously described in this chapter. Viability assays were performed after 24 hours of cell incubation with the appropriate uranium and bicarbonate concentration treatment. Samples of each treatment were plated and incubated on 5\% PTYG hard media and then counted for colony-forming units (CFU) (Figure 25). As expected, the cells treated with a 
high concentration of $\mathrm{U}(\mathrm{VI})$ and low bicarbonate were less viable than those treated with a high bicarbonate concentration.

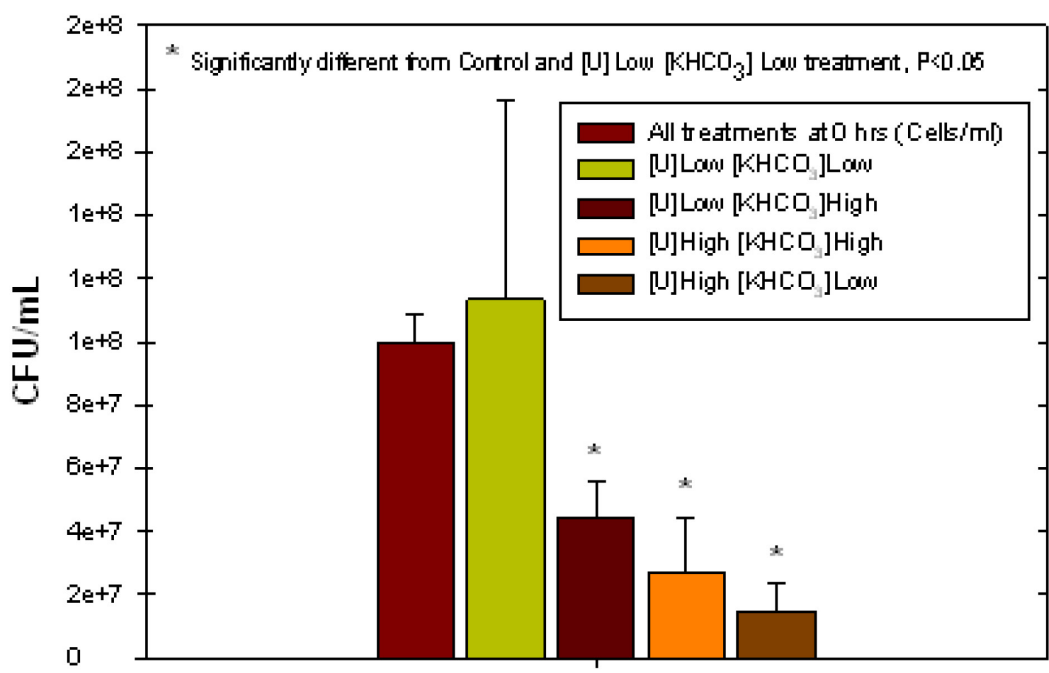

Type of treatments

Figure 25. Colony Forming Units $(\mathrm{CFU} / \mathrm{mL})$ of all treatments after 24 hours of exposure to bacteria $(\mathrm{n}=3)$.

These results support the theory that bicarbonate bound uranium forms highly soluble $\mathrm{U}(\mathrm{VI})$-carbonate complexes that apparently lessen the $\mathrm{U}$ toxicity on bacterial cells. The same trend was not observed for the low concentrations of uranium tested. This could be attributed to a higher cell density in one of the samples bearing the low uranium and bicarbonate concentrations, which apparently caused higher standard deviations for this treatment. To test the hypothesis that the presence of bicarbonate reduces the toxicity of $\mathrm{U}(\mathrm{VI})$ on bacterial cells growth, the experiment was extended to evaluate the cell growth by means of a spectrophotometer at $660 \mathrm{~nm}$ wavelength. The measurement of cell concentrations in bacterial suspensions by optical density yielded a linear relationship with a high correlation coefficient $\left(\mathrm{R}^{2}>0.99\right)$ (Figure 26). The time-dependent changes in 
absorbance in a parallel experiment, examining the toxicity of U(VI) on cells growth, revealed that the addition of bicarbonate in the control set did not impair cell growth $(\mathrm{P}>0.718)$. The cell densities for uranium-free controls converged at $8.7 \mathrm{E} 8 \mathrm{cells} / \mathrm{mL}$ over the testing period of $51 \mathrm{~h}$ (Figure 27). The addition of $20 \mathrm{ppm}$ of U(VI) caused an average $68.5 \%, 24.3 \%$, and $10 \%$ reduction in cell density over the same time period for bicarbonate-free, $5 \mathrm{mM}$ and $10 \mathrm{mM}\left[\mathrm{HCO}_{3}\right]$ concentrations, correspondingly, compare to U(VI)-free controls (Figure 27).

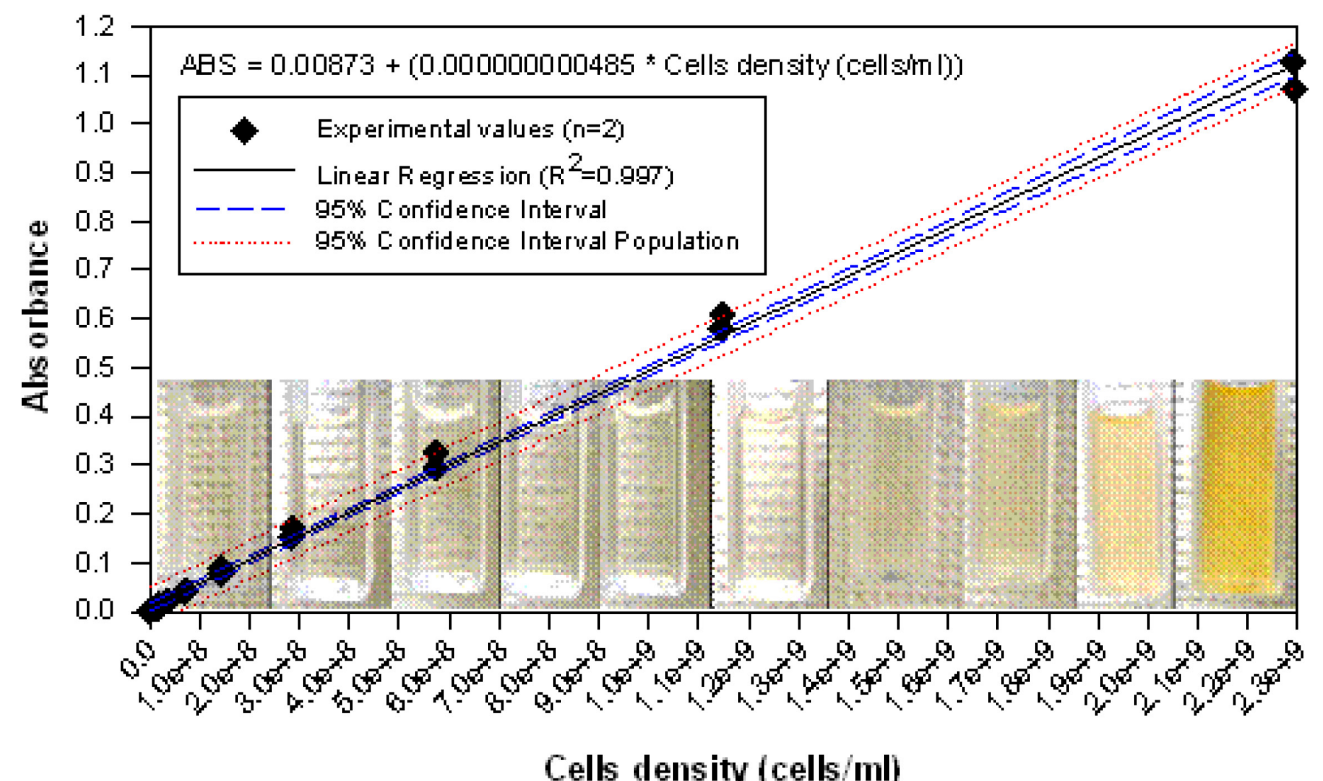

Figure 26. Spectrophotometer calibration curve for $A$. G975 in 5\% PYTG medium. 


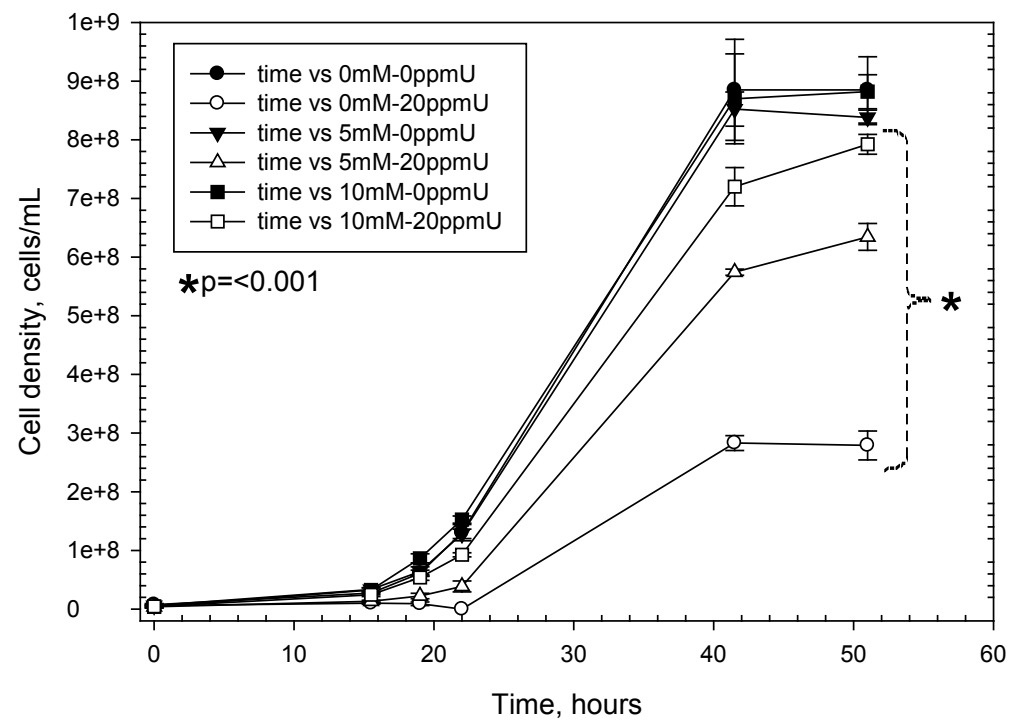

Figure 27.Time-depended changes in Arthrobacter G975 cells density grown in U(VI)free and $20 \mathrm{ppmU}(\mathrm{VI})$ amended $5 \% \mathrm{PTG}$ media altered with $0 \mathrm{mM}, 5 \mathrm{mM}$, and $10 \mathrm{mM}$ of $\mathrm{KHCO}_{3}, \mathrm{pH} 7.3,25^{\circ} \mathrm{C}(\mathrm{n}=3)$.

\section{Effect of uranium on microbial surfaces using atomic force microscopy}

Arthrobacter have developed very efficient molecular adaptation mechanisms that enhance the stability of nucleic acids, proteins, and lipids, allowing the bacteria to survive in stressful conditions (65). This phenomenon is associated with cell metabolism and, reportedly, with a very efficient phosphatase-mediated mechanism that the bacteria created to activate the secretion of phosphate groups. In fact, they can produce excess orthophosphate protecting cells from the toxic effects of radionuclides via passive U(VI) complexation by the negatively charged cell wall extracellular polymers (42)(66)(39). Uranium bioprecipitation reactions involving ligands, liberated by phosphatase activity, result in a deposition of $\mathrm{U}(\mathrm{VI})$ on the bacterial cell wall as crystalline uranyl phosphate 
minerals (67). Despite considerable efforts to develop an understanding of how bacteria mediate biomineralization, our knowledge is far from complete and further research is needed to evaluate the interactions between uranyl ions and microbes.

Atomic force microscopy (AFM) was used to monitor changes at the nanoscale level in cell surface topography, roughness and adhesion before and after the cells exposure to various concentrations of uranium. The aim of this task was to present high-resolution AFM results on the formation of microbial uranyl-phosphate precipitates on the bacterial surface. The results demonstrated the ability of this method to qualitatively and quantitatively analyze uranium precipitation on live bacterial cell surfaces of various strains of Arthrobacter sp.

\section{Uranium precipitation on the microbial cell surface}

Microscopic observations specified the cell surface localized bioprecipitation of uranium. The phase images in Figure 28-Figure 29 [the image on the left represents the height data ( $\mathrm{Z}$ range $250 \mathrm{~nm}$ ) and the image on the right represents the phase data (phase angle $60^{\circ}$ )] revealed extracellular precipitates deposited on the surface of uranium-loaded cells. Uranium precipitation is distinctly visualized as clearly defined crystalline deposits on the cell surface of uranium-treated samples. For the uranium-free control samples, the formation of precipitates was not observed (Figure 28). 


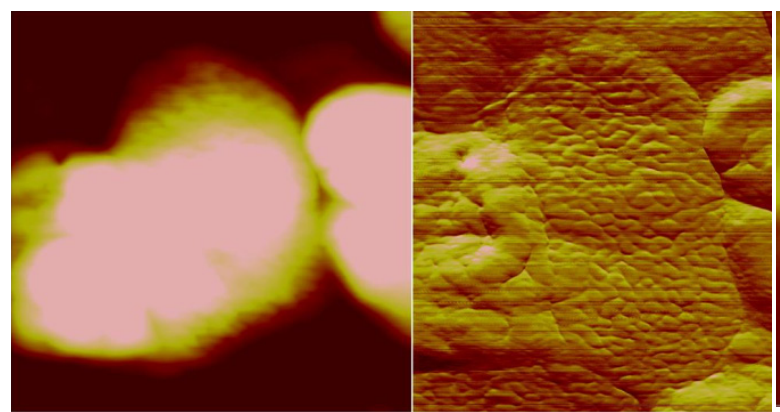

Figure 28. G975 control sample (scan size 2.94

$\times 2.94 \mu \mathrm{m} 2$ ) showing its unusual wrinkled surface morphology. The topagraphy image on the left ( $\mathrm{Z}$ range $200 \mathrm{~nm}$ ) and frictional image $(0.3 \mathrm{~V})$ on the right.

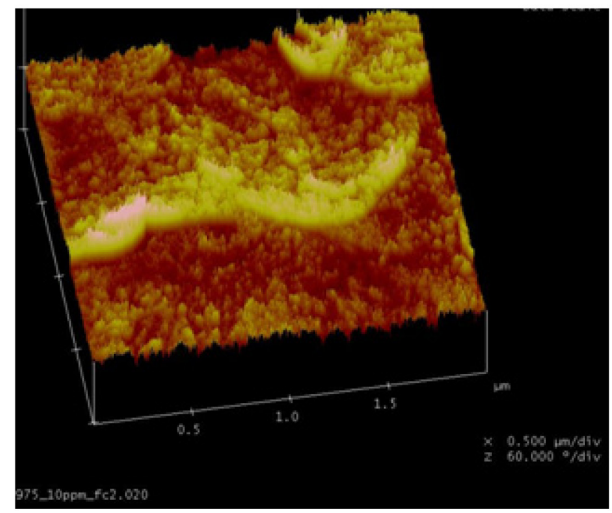

Figure 30. 3D micrograph of cell surface topology of G975 cultured in the media amended with $10 \mathrm{ppm}$ of $\mathrm{U}(\mathrm{VI})$. Scan size $2 \mu \mathrm{m}$.

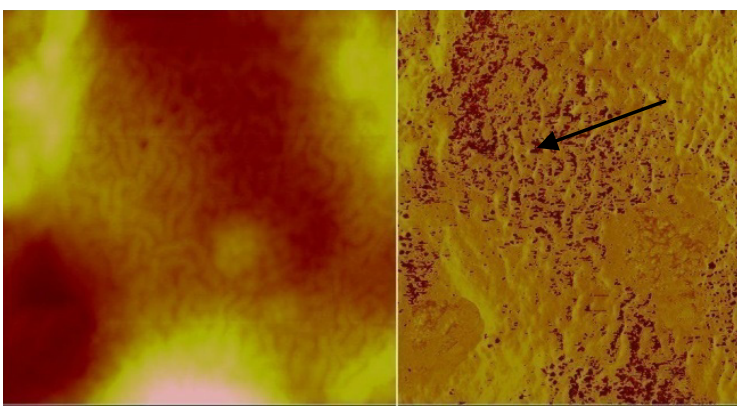

Figure 29. G975 cultured in the media amended with $10 \mathrm{ppm}$ of U(VI), (scan size $1.45 \times 1.45 \mu \mathrm{m} 2$; phase angle $60^{\circ}$ ). Phase image clearly shows crystalline deposition on the cell surface.

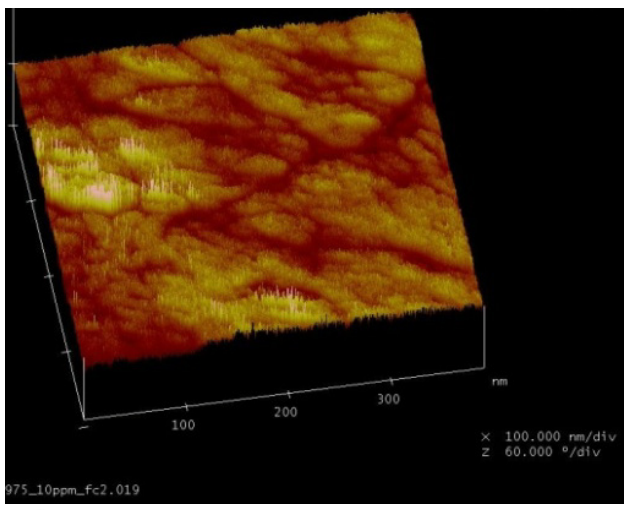

Figure 31. 3D micrograph of cell surface topologies of G975 cultured in the media amended with 10ppm of U(VI). Scan size $389 \mathrm{~nm}$.

3D AFM phase images show the variation in the G975 bacterial surface when treated with $10 \mathrm{ppm}$ of $\mathrm{U}(\mathrm{VI})$. Brighter areas are an indication of higher adhesion regions due to higher surface elevation of uranium precipitates on the surface and darker regions correspond to lower adhesion areas of bacterial surface (Figure 30, Figure 31). Brighter regions visualized on the cell surface can explain a significant increase in the surface roughness and changes in the adhesion forces. 
The identification of the deposit composition was achieved by EDS analysis. EDS spectrums of uranium-loaded samples has confirmed the presence of uranium in the cell surface elemental composition, which was primarily composed of uranium (U), oxygen $(\mathrm{O})$, phosphorus $(\mathrm{P})$, sodium $(\mathrm{Na})$, silica $(\mathrm{Si})$ and potassium $(\mathrm{K})$. The identity of cellsurface localized crystals was proven to be uranyl phosphate, as reported in previous research (35)(66)(67).

The precipitates accumulated on the surface of the G975 bacteria were clearly seen on the surface. Its large adsorption capacity may be due to the unique irregular surface structure of the G975 strain, which is seen in the topographic image (on the left, $Z$ range $200 \mathrm{~nm}$ ) and frictional image (on the right, $0.3 \mathrm{~V}$ ) presented in Figure 29. The unusual wrinkled cell wall region may offer a larger surface area to provide higher accessibility for reaction with the soluble uranium for the formation of biogenic uranium precipitates. It was noted earlier that high surface area geometries can enhance reaction turnover rates (68). In addition, it was observed that higher concentrations of uranium in media solutions are well correlated with an increase in uranium bioprecipitation on the cell surface. This was supported by EDS analysis of samples prepared on cells cultivated in media amended with various concentrations of $\mathrm{U}(\mathrm{VI})$. The EDS spectrum data indicate that higher U(VI) content found on the bacterial cell surface correlates with higher concentrations of uranium loaded to the culture broth (Table 5). In addition, samples with added bicarbonate have less $\mathrm{U}(\mathrm{VI})$ content compared to the control $(\mathrm{P}<0.004)$.

Table 5. Average U(VI) bioaccumulation by Arthrobacter bacterial cells $(n=3)$

\begin{tabular}{|c|c|}
\hline Strain & G975 \\
\hline
\end{tabular}




\begin{tabular}{|c|c|c|c|c|c|}
\hline $\mathrm{U}(\mathrm{VI}), \mathrm{ppm}$ & 9.5 & 20 & 20 & 20 & 27 \\
\hline$\left[\mathrm{KHCO}_{3}\right], \mathrm{mM}$ & 0 & 0 & 5 & 10 & 0 \\
\hline $\mathrm{U}$ weight, \% & $0.52 \pm 0.25$ & $2.29 \pm 0.88$ & $0.58 \pm 0.37$ & $0.29 \pm 0.24$ & $2.82 \pm 0.8$ \\
\hline
\end{tabular}

\section{Roughness Analysis}

Changes in the cells' surface roughness for the bacteria before and after exposure to various concentrations of uranium were monitored using AFM roughness analysis (Table 6). Exposure was for $24 \mathrm{hrs}$ and the concentrations of uranium ranged from $0.5 \mathrm{ppm}$ to $19.5 \mathrm{ppm}$.

Table 6. The average roughness (Ra) and a standard deviation (SD) of three Arthrobacter strains grown at various concentrations of uranium.

\begin{tabular}{|c|c|c|}
\hline \multirow{2}{*}{$\begin{array}{c}\text { Uranium } \\
\text { Concentration }\end{array}$} & \multicolumn{2}{|c|}{$\mathrm{G} 975$} \\
\cline { 2 - 3 } & $\begin{array}{c}\text { Mean Ra } \\
\text { (nm) }\end{array}$ & SD \\
\hline U-free controls & 3.88 & 2.33 \\
\hline $0.5 \mathrm{ppm}$ & 8.48 & 2.64 \\
\hline $5 \mathrm{ppm}$ & 6.05 & 1.59 \\
\hline $10 \mathrm{ppm}$ & 7.12 & 1.09 \\
\hline $19.5 \mathrm{ppm}$ & 9.01 & 2.67 \\
\hline
\end{tabular}

From Table 6, it is clear that the difference in the mean roughness values among the treatments is not great enough to exclude the possibility that its due to random sampling variability $(\mathrm{P}=0.8)$. For this reason, no trend or correlation was observed between the increase in uranium concentration and the roughness values for G975 Arthrobacter. It was anticipated that the roughness parameter would increase with higher uranium concentration, since an increase in uranium bioprecipitation on the bacterial surface was 
detected via EDS analysis and AFM. The relationship between roughness values and bacterial cells surface changes occurring with uranium exposure are not fully understood and require further investigation.

\section{Force Spectroscopy Analysis}

In previous studies, it has been shown that adhesion forces are very sensitive to surface modifications (69). Therefore, physiochemical changes occurring on bacterial cell surface membranes, when treated with various concentrations of uranium, were monitored with force spectroscopy analysis. Table 7 demonstrates that changes in the adhesion force values of the control and uranium-treated samples is due to the increase in uranium concentration in the cultivation media, which caused chemical modifications of the bacterial cell surface. This significant change may be due to the physico-chemical reactions on the cells surface resulting in extracellular uranium deposition via secretion of extra orthophosphate, protecting cells from the toxic effects of uranium (35). The results shown in Table 7 indicate a significant statistical difference in adhesion values between

control samples and those exposed to uranium: $10.02 \mathrm{nN}$ for G975 treated with $5 \mathrm{ppm}$ of U(VI). The data suggests that the bacteria has a unique adhesion force parameter $(\mathrm{P}<0.001)$ that decreases exponentially as the uranium concentration is increased.

Table 7. Comparison of adhesion forces for G975 Arthrobacter sp.

\begin{tabular}{|l|l|}
\hline & G975 \\
\hline
\end{tabular}




\begin{tabular}{|c|c|c|} 
& $\begin{array}{c}\text { Adhesion } \\
(\mathrm{nN})\end{array}$ & $\mathrm{SD}$ \\
\hline Control & 26.48 & 0.69 \\
\hline $5 \mathrm{ppm}$ & 16.45 & 0.15 \\
\hline $10 \mathrm{ppm}$ & 15.86 & 0.7 \\
\hline $10.5 \mathrm{ppm}$ & 6.1 & 0.15 \\
\hline
\end{tabular}

\section{Bioleaching of $\mathrm{U}(\mathrm{VI})$ from autunite}

In the non-contact mode experiments using sterile cultureware with inserts (Figure 32), the $\mathrm{U}(\mathrm{VI})$ leaching was investigated with the autunite mineral separated from the bacteria. The release of aqueous $\mathrm{U}(\mathrm{VI})$ over time during the autunite leaching in noncontact experiments is presented in Figure 33. The steady-state maximum concentrations of $\mathrm{U}(\mathrm{VI})$ detected were $1.0 \pm 0.7,1.1 \pm 0.6,1.2 \pm 0.9$, and $4.6 \pm 3.11$ fold higher than the abiotic control without the bicarbonate amendment. Even though these values are lower than those found in the bacteria-mineral mixed contact experiment, the amount of leached $\mathrm{U}(\mathrm{VI})$ between treatment groups is not great enough to exclude the possibility that the difference was due to random sampling variability $(\mathrm{P}=0.161)$. Factors that may have attributed to this increase in variability include slower uranium diffusion between the autunite- containing wells and the bacteria-bearing inserts, and the possible presence of bacterial cells in the aliquot samples withdrawn from the inserts, which were not filtered before KPA analysis. Similarly, after bacteria inoculation, U(VI) concentrations, measured in the reactors, increased $0.5 \pm 0.3,1.1 \pm 0.9,3.1 \pm 1.3,4.3 \pm 3.0$, and $3.2 \pm 1.4$ fold, 
respectively, compared to the $\mathrm{U}(\mathrm{VI})$ concentration at steady-state prior to inoculation (Figure 34). More replicates are required to draw statistically significant results.

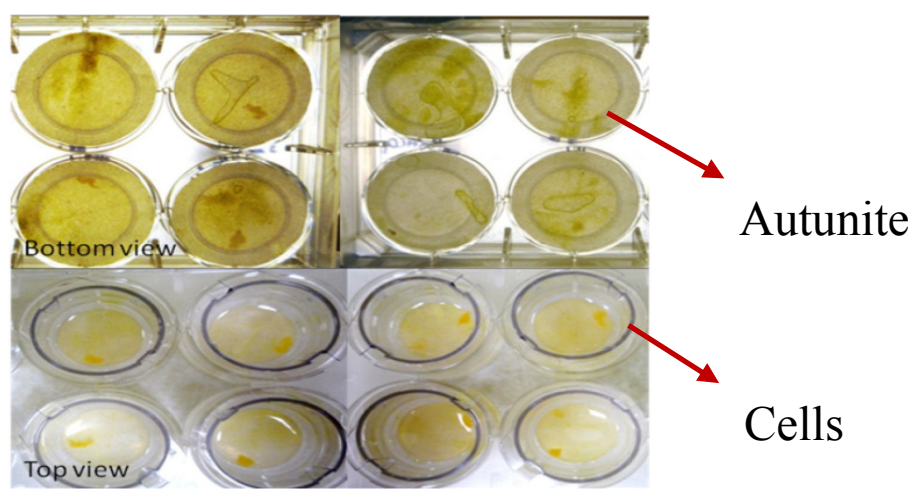

Figure 32. Top and bottom view of Cell Culture Insert with autunite mineral powder separated from bacteria.

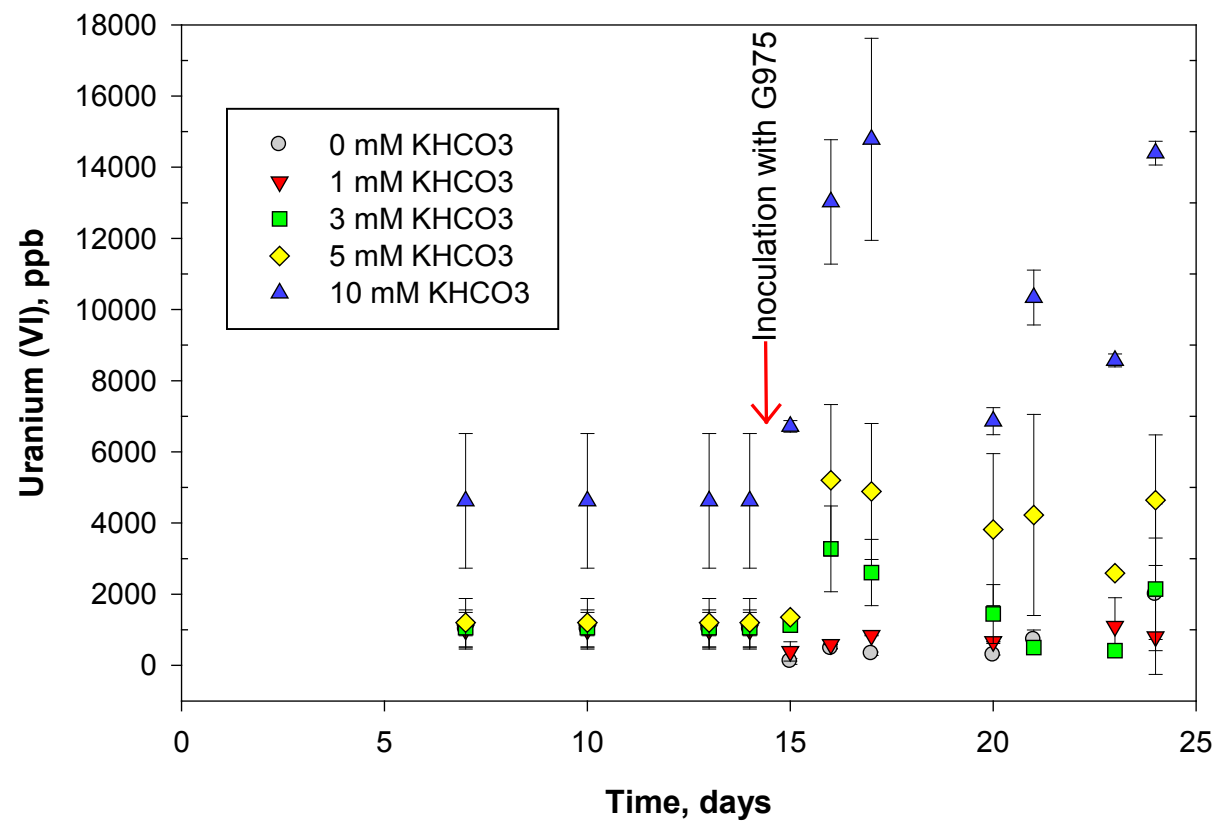

Figure 33. Changes for aqueous U(VI) as a function of time for the non-contact natural autunite dissolution insert experiments inoculated with Arthrobacter G975 strain separated by a 0.4 um porous membrane $(n=2)$. 


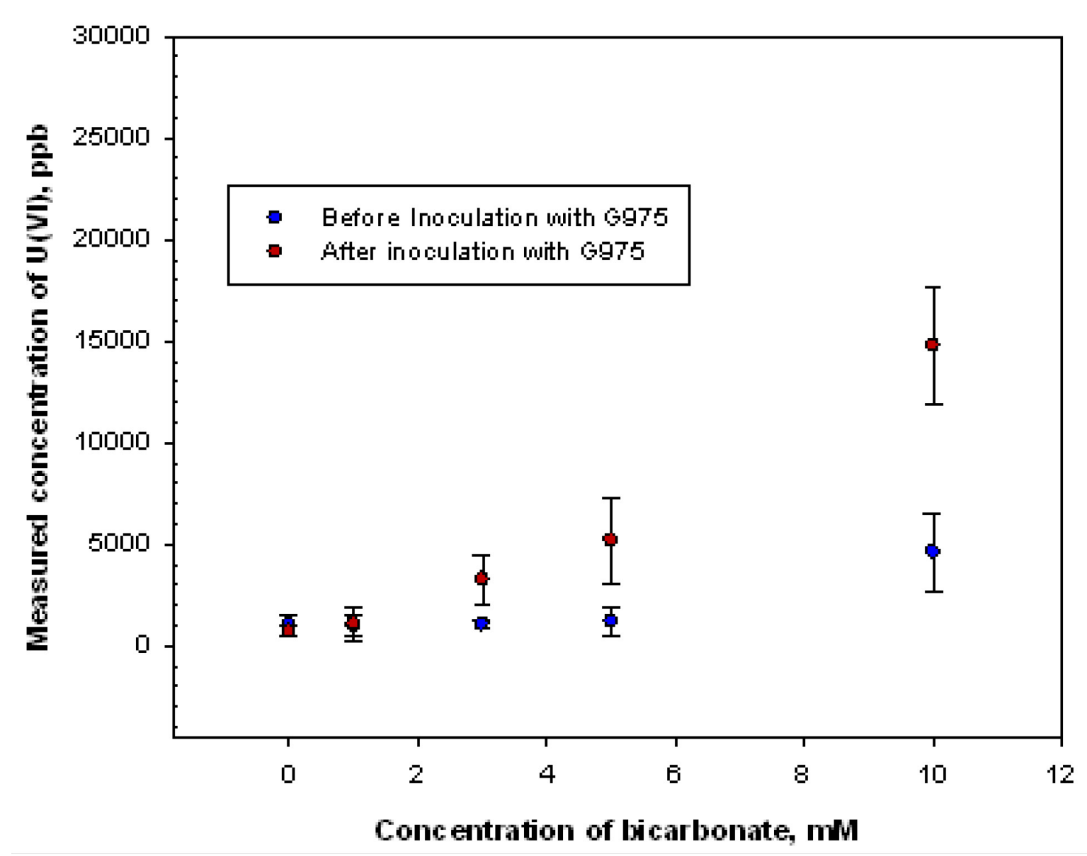

Figure 34. Measured U(VI) concentrations before and after inoculation with G975 in the insert non-contact natural autunite dissolution experiment $(n=2)$.

The results show that bacteria could be responsible for further autunite dissolution through secretion of metabolites, and are able to influence U(VI) leaching while not in direct contact with the mineral. This process was not related to media acidification since a substantial drop in $\mathrm{pH}$ on the surrounding medium was not recorded. The $\mathrm{pH}$ of $20 \mathrm{mM}$ Na-HEPES buffered media was not stable over the course of the experiment and was observed in the range of 7-8.4, slowly drifting from the initial value of 7.5. This change is mostly due to the equilibration of carbonate-containing media solution with the atmosphere. Thus far, there is no available research that investigated microbial dissolution of autunite in the aerobic conditions to which the results can be compared.

Phosphorous $(\mathrm{P})$ is an essential nutrient requirement for bacteria for the synthesis of DNA, ATP, polyphosphates, and cell wall phospholipids. In addition, bacteria create a 
very efficient phosphatase-mediated mechanism to activate excess secretion of orthophosphate, protecting cells from the toxic effects of radionuclides via passive U(VI) complexation by the negatively charged cell wall extracellular polymers (35)(42)(66)(39). These requirements force microorganisms to access insoluble phosphate-bearing minerals via microbial dissolution. It is well known that many soil microorganisms are able to dissolve P-bearing minerals (70)(71). These results indicate that such mechanisms may not depend on physical contact with uranium bearing minerals. The mechanisms to scavenge P from insoluble mineral sources are discussed by several authors. Some considered that microorganisms produce and exudates low molecular weight organic acids that play a role in the solubilization of inorganic phosphate from minerals $(70)(71)$.

Grown in phosphorus-limiting 5\% PTG media, bacteria were forced to liberate P by breaking the O-P bond from autunite sheets. A similar effect was noted by Smeaton et al. (72), who examined the release of $U$ from the meta-autunite mineral by the dissimilatory metal-reducing bacterium Shewanella putrefaciens 200R. Their spectroscopy measurements (XANES) indicated that the $\mathrm{U}$ dissolution was promoted by the uptake and immobilization of $\mathrm{P}$ by the bacterial cells. It is possible that the bacteria can oxidize media organics to powerful organic acids which, in turn, dissolve the phosphate in the solution. 


\section{CONCLUSIONS AND FUTURE WORK}

It was confirmed that Arthrobacter sp. G975, which roughly accounted up to $25 \%$ of subsurface isolates, can effectively remove soluble U(VI) ions from aqueous solution. The U(VI) biouptake for these microbes obtained by conducting a $2^{2}$ factorial design experiment was between $83-90 \%$ for the aqueous solutions at equilibrium with $\mathrm{CO}_{2}$ atmospheric pressure and uranium concentrations up to $15 \mathrm{ppm}$.

Kinetics data analysis confirmed that the process follows a pseudo second-order kinetics model $\left(\mathrm{R}^{2}>0.991\right)$. The equilibrium for biosorption experiments was reached at 24 hours. It was conclusively proven that bicarbonate ions affect the sorption behaviors of U(VI). The maximum biosorption capacity of U(VI) ions at $25^{\circ} \mathrm{C}$ by Arthrobacter sp. G975 was observed at $154.7 \pm 60.6,42.4 \pm 10.8,20.6 \pm 6.5$, and $5.5 \pm 8.0 \mathrm{mg} / \mathrm{g}$ for $0,0.5,2.5,5 \mathrm{mM}$ bicarbonate-bearing solutions, respectively. The incremental increase in aqueous bicarbonate concentrations exponentially reduced the U(VI) microbial uptake compared to values obtained in carbonate-free SGW. Experimental data indicates that bicarbonate concentrations of $0,0.5,2.5$ and $5 \mathrm{mM}$ reduced the maximum $\mathrm{U}(\mathrm{VI})$ uptake by $0 \%$, $72 \pm 13 \%, 87 \pm 7 \%$ and $96 \pm 5 \%$, respectively. The linear isotherm models produced a higher correlation coefficient with the experimental data than the Freudlich and Langmuir adsorption models. Despite the large biosorption capacity, there is experimental evidence to suggest that in addition to uranium adsorbed on the cell surface, some uranium is also accumulated inside the cell. In the presence of bicarbonate, when highly soluble and mobile carbonate complexes dominate the aqueous speciation of U(VI), the viability of cells treated with high concentration of $\mathrm{U}(\mathrm{VI})$ was noted to increase. 
Visual MINTEQ was applied to evaluate the aqueous speciation of the solutions with respect to key minerals and aqueous phases. The most positive and trimeric species of uranium changed in concentration as a function of bicarbonate and uranium concentrations present in solution. Uranium bioavailability to the cells that may be sorbed or toxic to the cells is reduced with concentrations greater than $2.5 \mathrm{mM}$ of bicarbonate.

AFM was used to investigate qualitative and quantitative changes on microbial cell surfaces when the cells interact with the uranyl ion. Quantitative results show the ability to capture the surface phenomenon for G975 strains of Arthrobacter sp. It was found that the level of precipitation is not uniform across the cell membrane. Roughness analysis shows that an increase in the uranium concentration does not have any significant effect on cell surface roughness for all strains $(\mathrm{P}>0.012)$. The force spectroscopy results reveal an exponential decay relationship between the adhesion force and the concentration of uranium added to the growth media. The microbes have a unique adhesion force parameter $(\mathrm{P}<0.001)$ that decreases as the uranium concentration is increased. Further, force spectroscopy results indicate that the cell membrane adhesion properties change due to chemical interactions with various concentrations of uranium.

The effect of bicarbonate on autunite mineral microbial leaching was evaluated in a bacteria- autunite non-contact mode employing cultureware with inserts comprised of autunite powder, media solution and bacteria.

In a non-contact autunite biodissolution, the steady-state maximum concentrations of U(VI) detected were $1.0 \pm 0.7-4.6 \pm 3.1$ fold higher than the abiotic control without the bicarbonate amendment. After bacteria inoculation, U(VI) concentrations increased 
$0.5 \pm 0.3-3.2 \pm 1.4$ fold compared to $\mathrm{U}(\mathrm{VI})$ concentration at steady-state prior to inoculation. A non-statistically significant increasing trend from the effect of bacteria on autunite leaching was observed as bicarbonate concentrations were increased in the solution. The data suggests that bacteria is responsible for autunite dissolution and is able to influence U(VI) leaching while not in direct contact with the mineral.

This study provides a better understanding of the capabilities of one of the most prevalent bacteria species at the Hanford Site. We can conclude that Arthrobacter G975 bacteria can influence the fate and transport of uranium in the subsurface since they possess a $\mathrm{K}_{\mathrm{d}}$ value that is greater than that of the native soil, are able to survive in oligotrophic and uranium rich environments, have the ability to adsorb and accumulate $U$ efficiently, and can indirectly breakdown stable uranyl-phosphate minerals found in the subsurface as a result of remedial actions. This specific Arthrobacter strain is a distinguished microbe ideal for subsurface uranium bioremediation. The research presented here provides new parameters useful for modeling and evaluating uranium mobility, and remedial actions.

Further testing is recommended to completely understand the mechanism of microbial uranium uptake and the bacterial effect on uranium leaching from minerals. Future studies should involve other factors that may affect this process including $\mathrm{pH}$, calcium concentrations, and temperature. 


\section{PUBLICATIONS \& POSTER PRESENTATIONS}

Katsenovich, Y., Carvajal D., Guduru, R., Lagos L. Li, C-z. Assessment of the Resistance of Hanford Site Arthrobacter Isolates to Uranium (VI) Exposure. Under review in the Geomicrobiology Journal.

Guduru, R., Carvajal, D., Katsenovich Y., Lagos L., McDaniel D., and Chen-zhong Li. Investigation of Effect of Uranium on Microbial Surfaces Using Atomic Force Microscopy. In the proceeding of the Waste Management Conference, Feb 27 -March 3, 2011, Phoenix, AZ.

Banerjee, R., Carvajal, D., Katsenovich,Y., Lagos L, Tansel, B.,and Li, C-z. Response of Hanford Site Soil Arthrobacter Isolates to Uranium Contamination. In the proceeding of the Waste Management Conference, March 7-11, 2010, Phoenix, AZ.

Carvajal, D., Plymale, A., Konopka, A., Fredrickson, J., Xueju, L. Uranium Toxicity to Native Microbial Communities in the Hanford 300 Area Groundwater. Manuscript is in the final stages for Environmental Science and Technology journal submission.

Roelant, D., Lagos, L., Katsenovich, Y., Prabhakar, P., Gudavalli, R., Varona, J., Zidan, A., Idarraga, M., Banerjee, R., Carvajal, D., Lima, N., Hernandez, R. Rapid Deployment of Engineered Solutions for Environmental Problems at Hanford. Final technical report Feb 2005 to May 2010. Prepared for the U.S.D.O.E. Office of Environmental Management.

Roelant, D., Lagos, L., Katsenovich, Y., Prabhakar, P., Gudavalli, R., Carvajal, D., Guduru,R, Betancourt, A,, Ariaz, Y., Barroso, M., Ng, S., Henao, A , 2011. Advancements in Rapid Deployment of Engineered Solutions for Environmental Problems at Hanford. Yearend technical report prepared for the U.S. DOE Office of Environmental Management under grant No. DE-FG01-05EW07033

Carvajal, D. A Study of Uranium Biosorption by DOE-Hanford Site Soil Isolates: Effect of pH and Carbonate (poster). Awarded as the best poster in the student poster competition at the Waste Management Conference, 2010, Phoenix, AZ. 


\section{LIST OF REFERENCES}

1. Geochemical controls on Contaminant Uranium in Vadose Hanford formation sediments at the 200 and 300 area, Hanford Site, Washington. McKinley, James P., Et al. 2007, Vadoze Zone Journal, pp. 1004-1017.

2. The chemical thermodynamics of uranium. Grenthe, I., Fuger, J., Konings, R.J.M., Lemire, R.J., Muller, A.B., Nguyen-Trung, C., Wanner. 1992, Elsevier, pp. 30-83.

3. The crystal chemistry of uranium. In P.H. Ribbe, Ed., Uranium: Mineralogy, Geochemistry and the Environment. Burns, P.C. 1999, Reviews in Mineralogy, Mineralogical Society of America, pp. 23-90.

4. Uranium (VI) complexation with citric, humic and fulvic acids. Lenhart J.J., Cabaniss S.E., MacCarthy P., and Honeyman B.D. 2000, Radiochim, pp. 345-353.

5. Surface Complexation Modeling of Uranium (VI) Adsorption on Natural Mineral Assemblages. Davis, J.A. 2001, Report NUREG/CR-6708. U.S. Nuclear Regulatory Comission.

6. Comparative analysis of soluble phosphate amendments for the remediation of heavy metal contaminants:effect on sediment hydraulic conductivity. Wellman D.M., Icenhower, J.P., and A.T. Owen. 2006, Environmental Chemistry, pp. 219-224.

7. Miettinen, I. T., Vartiainen, T., and P. J. Martikainen. 1997, Applied And Environmental Microbiology, p. 3242.

8. Geomicrobiology of high-level nuclear waste-contaminated vadose sediments at the Hanford Site, Washington State. Fredrickson, J. K., Zachara, J. M., Balkwill, D. L., Kennedy, D., Li, S. W., Kostandarithes, H. M., Daly, M. J., Romine, M. F. and Brockman, F.J. 2004, Applied and Environmental Microbiology, Vol. vol 70, p. 4230.

9. Survival of Arthrobacter crystallopoietes during prolonged periods of extreme desiccation. . Boylen, C.W. s.1. : Journal of Bacteriology, 1973, Vol. vol. 113, p. pp. 33.

10. Phylogenetic characterization of bacteria in the subsurface microbial culture collection. Balkwill, D. L., Reeves, R. H., Drake, G. R., Reeves, J. Y., Crocker, F. H., Baldwin K, M., and D. R. Boone. s.1. : FEMS microbiology reviews, 1997, Vol. vol. 20, pp. pp. 201-216.

11. Genetic diversity among Arthrobacter species collected across a heterogeneous series of terrestrial deep-subsurface sediments as determined on the basis of $16 S \mathrm{rRNA}$ and recA gene sequences. Van Waasbergen, L.G., Balkwill, D.L., Croocker, F.H., 
Bjornstad, B.N., and R.V.Miller. 2000, Applied and Environmental Microbiology, Vol. 66, pp. 3454-3463.

12. Phylogenetic and physiological diversity of Arthrobacter strains isolated from unconsolidated subsurface sediments. Crocker, F. H., Fredrickson, J. K., White, D. C., Ringelberg, D. B. and D. L. Balkwill. s.l. : Microbiology, 2000, Vol. vol. 146, p. pp. 1295.

13. Hot desert soil communities. Kieft, T.L. New York : John Wiley, 2002, Encyclopedia of environmental microbiology, pp. pp. 1576-1586.

14. Effect of Shadowing on Survival of Bacteria under Conditions Simulating the Martian Atmosphere and UV Radiation. S.Osman, Z. Peeters, M. T. La Duc, R. Mancinelli, P. Ehrenfreund, and K. Venkateswaran. s.l.: Applied and Environmental Microbiology, 2008, pp. 959-970.

15. Influence of Calcium on Microbial Reduction of Solid Phase Uranium(VI). Liu, Chongxuan, et al. s.l. : Biotechnology Bioengineering, 2007, Vol. 97.6, pp. 1415-1422.

16. Inhibition of Bacterial U(VI) Reduction by Calcium. Brooks, Scott, et al. s.l. : Environ Sci Technol, 2003, Vol. 37, pp. 1850-1858.

17. Langmuir, D. Aqueous Environmental Geochemistry. s.l. : Prentice Hall, Inc., 1997. p. 602 .

18. Environmental Aqueous Geochemistry of Actinides. In Uranium: mineralogy, geochemistry and the environment. L., Murphy W. M. and Shock E. s.l. : Mineralogical Society of America., 1999, Vol. Vol. 38, pp. pp. 221-254.

19. Adsoption of aqueous uranyl complexes onto bacillus subtilis cells. Gorman-Lewis, Dre, et al. s.1. : Environmental Science and technology, 2005, Vol. 39, pp. 4906-4912.

20. Systematics and paragenesis of uranium minerals. Robert Finch, and Takashi Murakami. 1, s.l. : Reviews in Mineralogy and Geochemistry, 1999, Vol. v. 38, pp. p. 91179.

21. Uranium solution-mineral equilibria at low temperatures with applications to sedimentary ore deposits. Langmuir, D. 1978, Geochimica et Cosmochimica Acta, Vol. 42, pp. pp. 547-569.

22. Uranyl(VI) carbonate complex formation: validation of the Ca2UO2(CO3)3(aq.) species. Bernhard, G., Geipel, G., Reich, T., Brendler, V., Amayri, S., Nitsche, H. 2001, Radiochim., Vol. Acta 89, pp. 511-518. 
23. Chemical Thermodynamics. Guillaumont R, Fanghanel T, Fuger J, Grenthe I, Neck V, Palmer DA, Rand MH. s.1. : Elsevier, 2003, OECD Nuclear Energy Agency, Vol. vol. 5, p. p. 919.

24. Mixed Ca2+/UO22+/CO32-complex formation at different ionic strengths. . Kalmykov, S. N. and Choppin, G. R. 2000, Radiochim., Vol. Acta. 88, pp. p.603-606.

25. Uranium Geochemistry, Mineralogy, Geology, Exploration and Resources. de Vivo B, Ippolito F, Capaldi G, Simpson PR (eds). London: The Institution of Mining and Metallurgy, 1984, pp. pp 43-88.

26. 300 Area Uranium Stabilization Through Polyphosphate Injection: Final Report. Vermeul, VR., Bjornstad, BN., Fritz, B.G., Frutcher, JS., Mackley, RD., Mendoza, D.P., Newcomer, D.R., Rochhold, ML., Wellman, DM., Williams, M.D. s.l. : PNNL-18529, 2009, Prepared for the U.S. Department of Energy under Contract DE-AC0576RL01830.

27. U6+ minerals and inorganic phases: a comparison and hierarchy of crystal structures. Burns, P.C., Miller, M.L. and R.C. Ewing. s.l. : he Can. Mineralogist, 1996, Vol. 34, pp. p.845-880.

28. Effects of $p H$, temperature, and aqueous organic material on the dissolution kinetics of meta-autunite minerals, (Na, Ca)2-1[(UO2)(PO4)]2.3H2O. Wellman, DM., Icenhower, JP., Gamerdinger, A.P., Forrester, S.W. s.1. : American Mineralogist, 2006, Vol. V. 91, pp. p, 143-158.

29. Solubility of (UO2)3(PO4)2 $442 \mathrm{O}$ in $\mathrm{H}+-\mathrm{Na}+-\mathrm{OH}--\mathrm{H} 2 \mathrm{PO}-4-\mathrm{HPO} 2-4-\mathrm{PO} 3-4$ $\mathrm{H} 2 \mathrm{O}$ and its comparison to the analogous PuO2+2 system. Rai, D., Xia, Y., Rao, L., Hess, N.J., Felmy, A.R., Moore, D.A., and D.E. McCready. No. 4, s.l. : Journal of Solution Chemistry, 2005, Vol. 34.

30. Accumulation of metals by microorganisms and algae. GM, Gadd. VCH, Weinheim : Biotechnology, 1988, Vol. vol 6b, pp. pp 401-430.

31. Biosorption of Heavy Metals. Ahalya, N., Ramachandra, T.V., Kanamadi, RD. 4, s.1. : Res. J. Chem. Environ., 2003, Vol. Vol. 7, p. 71.

32. Heavy metal biosorption by fungal mycelia by-products: Mechanisms and influence of $p H$. Fourest, E. and J.C. Roux. s.l. : Applied Microbiol. Biotechnol., 1992, Vol. 37, pp. 399-403.

33. Biosorption of Heavy Metals. Volesky, B., Holan, Z. R. Montreal : Biotechnol. Prog., 1995, Vol. 11, pp. 235-250. 
34. Microbial transformations of uranium in wastes and implication on its mobility. Francis, A. Freiberg, Germany: . Proceedings of the International Conference on Uranium Mining and Hydrogeology UMH V TU Bergakademie, September 14-18, 2008.

35. Uranium biomineralization as a result of bacterial phosphatase activity: insights from bacterial isolates from a contaminated subsurface . Beazley, M. J., Martinez, R. J., Sobecky, P. A., Webb, S. M., and M. Taillefert. s.1. : Environ. Sci. Technol, 2007, Vol. vol. 41.

36. Complexation of Uranium by Cells and S-Layer Sheets of Bacillus sphaericus JGA12. Merroun ML, Raff J, Rossberg A, Hennig C, Reich T, Selenska-Pobell S. s.l.: Applied and Environmental Microbiology, 2005, Vol. 71(9), pp. 5532-5543.

37. Association of uranium with halophilic and nonhalophilic bacteria and archaea. A.J. Francis, J.B. Gillow, C.J. Dodge, R. Harris, T.J. Beveridge, and H.W. Papenguth. s.l. : Radiochim, 2004, Vol. Acta 92, pp. 481-488.

38. Resistance to, and accumulation of, uranium by bacteria from a uraniumcontaminated site. Suzuki Y. and Banfield, J. F. s.1.: Geomicrobiology Journal, 2004, Vol. vol. 21, pp. pp. 113-121.

39. Aerobic uranium (VI) bioprecipitation by metal resistant bacteria isolated from radionuclide and metal contaminated subsurface soils. Martinez, R. J., Beazley, M. J., Taillefert, M., Arakaki, A. K., Skolnick, J. and P. A. Sobecky. s.l. : Environmental Microbiology, 2007, Vol. vol. 9, pp. pp. 3122-3133.

40. Microbacterium isolates from the vicinity of a radioactive waste depository and their interactions with uranium. Nedelkova M, Merroun ML, Rossberg A, Hennig C, Selenska-Pobell S. s.1. : FEMS Microbiol. Ecol., 2007, Vol. 59, pp. 694-705.

41. Uranium bioaccumulation by Citrobacter sp. as a result of enzymically mediated growth of polycrystalline HUO sub 2 PO sub 4. Macaskie, L. E., Empson, R. M., Cheetham, A. K., Grey, C. P. and A. J. Skarnulis. Washington, DC : Science, 1992, Vol. vol. 257.

42. Phosphatase-mediated heavy metal accumulation by a Citrobacter sp. and related enterobacteria. . Macaskie, L. E., Bonthrone, K. M., and D. A. Rouch. s.1. : FEMS microbiology letters, 1994, Vol. vol. 121, pp. pp. 141-146.

43. E.F Mongodin, N. Shapir, S. C. Daugherty, R.T. DeBoy, J. B. Emerson, A. Shvartzbeyn, D. Radune, J. Vamathevan, F. Riggs, V. Grinberg, H. Khouri, L. P. Wackett, K. E. Nelson, M. Nedelkova, M. L. Merroun, A. Rossberg, C. Hennig, and S. Selenska-Pobell,. 2007, Fems Microbiology Ecology, Vol. 59, p. p. 964. 
44. Interaction mechanisms of uranium with bacterial strains isolated from extreme habitats. Merroun, M.L., Nedelkova, M., Rossberg, A., Hennig, C., Selenska-Pobell, S. s.1. : Radiochim, 2006, Vol. Acta 94, pp. 723-729.

45. Removal and recovery of uranyl ion using various microorganisms. Tsuruta, T. s.l. : J Biosci Bioeng, 2002, Vol. 94, pp. 23-28.

46. Adsorption of uranium from acidic solution by microbes and effect of thorium on uranium adsorption by Streptomyces levoris. Tsuruta, T. s.l. : J Biosci Bioeng, 2004, Vol. 97, pp. 275- 277.

47. Removal and recovery of uranium using microorganisms isolated from Japanese uranium deposits. Tsuruta, T. 2006, J Nucl Sci Technol, Vol. 43, pp. 896-902.

48. Experimental study of uranyl adsorption onto Bacillus subtilis. Fowle, D.A., Fein, J.B., Martin, A.M. s.l. : Environ. Sci. Technol, 2000, Vol. 34, pp. p. 3737-3741.

49. Code of Federal Regulation-Protection of Environment; Chap. I: Environment Protection Agency; Part 796: Chemical Fate Testing Guidelines; Subpart C; Sec. 796.2750: Sediment and Soil Adsorption Isotherm. EPA, US. 2004, Ref.40 CFR 796.2750 (7-1-03 edition), pp. 87-90.

50. Groundwater Sampling and Characterization of 300-FF-5 Uranium Plume Sediments and Groundwaters. Zachara, J.M., Smith, S.C. s.l.: Pacific Northwest National Laboratory, May 10-11 2004.

51. Assessment of sorbent/water ratio effect on adsorption using dimensional analysis and batch experiments. Chang, T.W., Wang, M.K. s.1. : Chemosphere, 2002, pp. pp. 419426.

52. Study on biosorption kinetics and thermodynamics of uranium $b$ citrobacter freudii. Xie, S., Yang, J., Chen, C., Zhang, X., Wang, Q., Zhang, C. s.l. : Journal of Environmental Radioactivity, 2008, Vol. 99 , pp. p. 126-133. .

53. Equilibrium and kinetic modelling of cadmium(II) biosorption by C. vulgaris in a batch system: effect of temperature. . Aksu, Z. s.l.: Separation and Purification Technology, 2001, Vol. 21 , pp. P. 285-294.

54. Cadmium removal from aqueous solutions by chitin: kinetic and equilibrium studies. . Benguella, B., Benaissa, H. s.1. : Water Research, 2002, Vol. 36, pp. P. 2463-2474. 
55. Effects of SEM Preparation Techniques on the Appearance of Bacteria and Biofilms in the Carter Sandstone. Fratesi, S.E., Lynch, F.L., Kirkland, B.L., and Brown, L.R.'. 2004, Journal of Sedimentary Research, pp. 858-867.

56. Comparison of hexamethyldisilazane and critical point drying treatments for SEM analysis of anaerobic biofilms and granular sludge. Araujo, J.C., Téran, F. C., Oliveira, R. A., Nour, E. A. A., Montenegro, M. A. P., Campos, J. R. and R. F. Vazoller. 2003, Journal of Electron Microscopy, pp. 429-433.

57. Fung, C. K. M., Seiffert-Sinha, K., Lai, K. W. C., Yang, R., Panyard, D., Zhang, J., $\mathrm{Xi}, \mathrm{N}$. and A. A. Sinha. Investigation of human keratinocyte cell adhesion using atomic force microscopy. s.l. : Nanomedicine: Nanotechnology, Biology and Medicine, 2010. pp. pp.191-200. Vol. vol. 6 .

58. Noy, A., Vezenov, D. V., Lieber, C. M. Chemical force microscopy. s.1. : Annual review of materials science, 1997. pp. 381-421. Vol. 27 (1).

59. Takano, H., Kenseth, J. R., Wong, S. S., O'Brien, J. C. and M. D. Porter. Chemical and biochemical analysis using scanning force microscopy. s.l. : Chem. Rev, 1999. pp. pp. 2845-2890. Vol. vol. 99.

60. Force-distance curves by atomic force microscopy. Cappella, B. and G. Dietler. s.l. : Surface Science Reports, 1999, Vol. vol. 34, pp. pp. 1-104.

61. Phylogenetic and physiological diversity of Arthrobacter strains isolated from unconsolidated subsurface sediments. F. H. Crocker, J. K. Fredrickson, D. C. White, D. B. Ringelberg and D. L. Balkwill. s.1. : Microbiology, 2000, Vol. 146, pp. 1295-1310.

62. Association of uranyl with the cell wall of Pseudomonas fluorescens inhibits metabolism. Leckie., R. Bencheikh-Latmani and J. s.l. : Geochimica et Cosmochimica, 2003, Vols. Acta, 67(21), pp. 4057-4066.

63. Determination of Bacteria Cell Dry Mass by transmission Electron Microscopy and Densitometric Image Analysis. $r$. Loferer-Krößbacher, M., Klima, J. and R. Psenne. s.1. : Appl Environ Microbiol, 1998, Vol. 64(2), pp. p.688-694.

64. Montgomery, Douglas C. The 2k Factorial Design . Design and Analysis of Experiments. 7th edition. New York : John Wiley \& Sons, INC. , 2008, pp. 207-229.

65. Secrets of soil survival revealed by the genome sequence of Arthrobacter aurescens TC1. Mongodin, E. F., Shapir, N., Daugherty, S. C., Deboy R. T., Emerson, J. B., Shvartzbeyn, A., Radune, D., Vamathevan, J., Riggs, F. and V. Grinberg. s.1. : PLoS Genet, 2006, Vol. 2, p. pp.e214. 
66. Uranyl precipitation by Pseudomonas aeruginosa via controlled polyphosphate metabolism. Renninger, N., Knopp, R., Nitsche, H., Clark, D. S. and J. D. Keasling. s.1. : Applied and environmental microbiology, 2004, Vol. vol. 70, p. pp. 7404.

67. Enzymically mediated bioprecipitation of uranium by a Citrobacter sp.: a concerted role for exocellular lipopolysaccharide and associated phosphatase in biomineral formation. Macaskie, L. E., Bonthrone, K. M., Yong, P. and Goddard, D. T. s.1.: Microbiology, 2000, Vol. 146, p. pp. 1855.

68. Biomedical surface scinece: Foundations to frontiers. Castner, D., Ratner, B. s.1. : Surface Science, 2002, Vol. 500, pp. 28-60.

69. Spherical AFM probes for adhesionf orce measurements on metal single crystals. Stegemann, B., Backhaus, H., and E. Santner. [ed.] A. \& DÍAZ, J.(Eds.) In MéndezVilas. s.1. : Modern Research and Educational Topics in Microscopy, 2007.

70. Vazques, P., Holguin, G., Puente, ME., Lopez-Cortes, A., Bashan, Y. s.l. : Biol. Fertil. Soil, 2000., pp. 460-468.

71. Bacterial mineral phosphate. Goldstein, A.H. s.l. : Am. J. Alt. Agric., 1986, Vol. 1(2), pp. p.51-57.

72. Bacterially enhanced dissolution of meta-autunite. Smeaton, C.M., Weisener,C.G., Burns,P.C., Fryer,B.J. and Fowle,D.A. s.1. : American Mineralogist, 2008, Vol. 93, pp. 1858-1864.

73. Sorption of Inorganic Mercury and Monomethyl Mercury in an Iron-Humus Podzol Soil of Southern Norway Studied by Batch Experiments. K.Schluter. 1997, Environmental Geology, pp. 266-279.

74. Assessment of sorbent/water ratio effect on adsorption using dimensional analysis and batch experiments. T.W.Chang, M.K.Wang. 2002, Chemosphere, pp. 419-426.

75. Aquatic Chemistry. Chemical equilibrium and rates in natural waters. W. Stumm, J.Morgan. 1996, John Wiley \& Sons, Inc, p. 1022.

76. Sorption equilibrium of mercury onto ground-up tree fern. Y.S.Ho, C.C.Wang. 2008, Journal of Hazardous Materials, pp. 1421-1430.

77. Dissolution kinetics of synthetic and natural meta-autunite minerals, X3-n(n)+ [(UO2)(PO4)]2 . xH2O, under acidic conditions . Wellman, DM., Gunderson, KM, Icenhower, JP., Forrester, S.W. 11, s.1. : Geochemistry, Geophysics, Geosystems, 2007, Vol. V.8. 
78. Kinetic and mechanisms of soil chemical reactions at the soil mineral/water interface. Sparks, D. s.1. : Soil Physical Chemistry, 1999.

79. Bioprocessing Of Rock Phosphate Ore: Essential Technical Considerations For The Development Of A Successful Commercial Technology. Goldstein, A.H. New Orleans : Proc. IFA Technical conference., 2000., pp. pp. 1-21.

80. Rock phosphate solubilization by soil bacteria. Ivanova, R., Bojinova, D., Nedialkov, K. s.1. : Journal of the University of Chemical Technology and Metallurgy, 2006., Vols. 41, 3, pp. 297-302. 